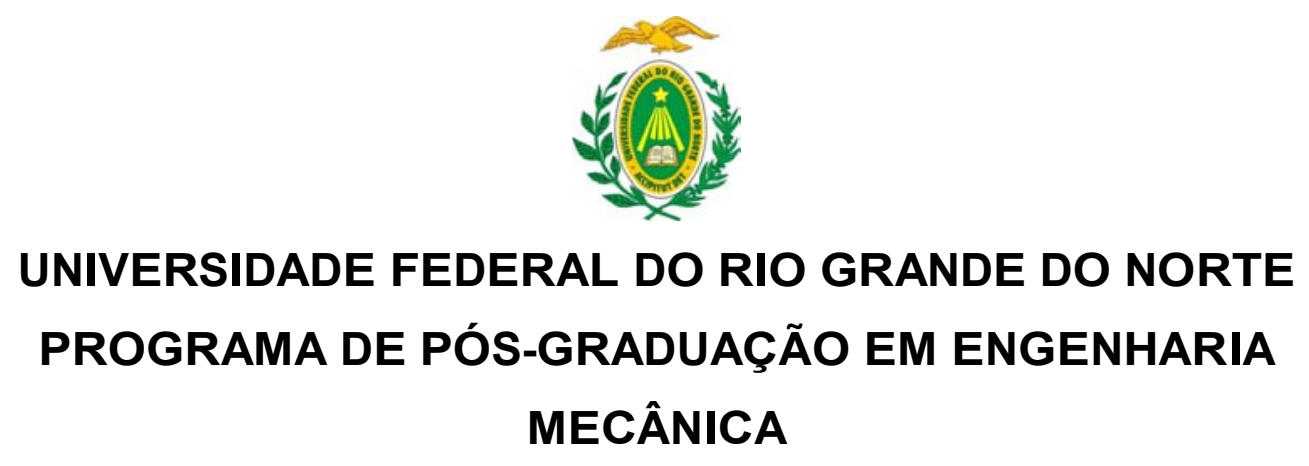

DISSERTAÇÃO DE MESTRADO

ANÁLISE DE VIABILIDADE TÉCNICA DE UTILIZAÇÃO DA FIBRA DE BANANEIRA COM RESINA SINTÉTICA EM COMPÓSITOS

RUI CARLOS DE SOUSA MOTA

Orientador: Prof. Dr. José Ubiragi de Lima Mendes Co-Orientador: Prof. Dr. José Hilton Ferreira da Silva 
UNIVERSIDADE FEDERAL DO RIO GRANDE DO NORTE PROGRAMA DE PÓS-GRADUAÇÃO EM ENGENHARIA MECÂNICA

\author{
DISSERTAÇÃO DE MESTRADO
}

\title{
ANÁLISE DE VIABILIDADE TÉCNICA DE UTILIZAÇÃO DA FIBRA DE BANANEIRA COM RESINA SINTÉTICA EM COMPÓSITOS
}

Dissertação submetida à

UNIVERSIDADE FEDERAL DO RIO GRANDE DO NORTE

como parte dos requisitos para a obtenção do grau de

MESTRE EM ENGENHARIA MECÂNICA

RUI CARLOS DE SOUSA MOTA

Orientador: Prof. Dr. José Ubiragi de Lima Mendes

Co-Orientador: Prof. Dr. José Hilton Ferreira da Silva 
UNIVERSIDADE FEDERAL DO RIO GRANDE DO NORTE PROGRAMA DE PÓS-GRADUAÇÃO EM ENGENHARIA MECÂNICA

\section{ANÁLISE DE VIABILIDADE TÉCNICA DE UTILIZAÇÃO DA FIBRA DE BANANEIRA COM RESINA SINTÉTICA EM COMPÓSITOS}

RUI CARLOS DE SOUSA MOTA
Esta dissertação foi julgada adequada para a obtenção do título de MESTRE EM ENGENHARIA MECÂNICA sendo aprovada em sua forma final.

Prof. Dr. José Ubiragi de Lima Mendes - Orientador

BANCA EXAMINADORA

\begin{tabular}{c}
\hline Nome - Presidente \\
\hline Nome \\
\hline Nome \\
\hline Nome
\end{tabular}

Natal - 2010 
Talhado para as grandezas

P'ra crescer, criar, subir, O Novo Mundo nos músculos Sente a seiva do porvir. -Estatuário de colossos Cansado doutros esboços Disse um dia Jeová:

"Vai, Colombo, abre a cortina "Da minha eterna oficina...

"Tira a América de lá".

Castro Alves 
Dedico este trabalho a minha mãe, meu pai (in memorian), minha esposa e minha filha, e aos irmãos e amigos. 


\section{AGRADECIMENTOS}

Agradeço a minha família, que me deu todo o apoio neste trabalho, a meus amigos, que de uma forma direta e/ou indireta contribuíram de forma incisiva nos momentos mais difíceis;

Ao meu orientador, que de forma incondicional apoiou este projeto;

Ao IFBA - Simões Filho, que através de seus gestores proporcionaram o meu ingresso neste mestrado;

Ao Programa de Pós-Graduação em Engenharia Mecânica da UFRN, a qual, através de convênio IFBA /UFRN, fizeram acontecer este curso;

À empresa Gerdau, na pessoa do Eng ${ }^{\circ}$. Sandro Gonçalves, que disponibilizou o laboratório de microscopia óptica para a realização de alguns ensaios;

Aos alunos do IFBA - SF que, de forma voluntária, muito contribuíram e incentivaram, fazendo com que este trabalho acontecesse. 


\section{RESUMO}

Este trabalho tem como objetivo apresentar a viabilidade de um compósito utilizando material descartado da lavoura da bananeira (pseudocaule), o qual é fibrilado juntamente com resina sintética em substituição à fibra de vidro, a ser utilizado em elementos estruturais que não demandem grandes esforços mecânicos, tais como reservatórios, calhas, domos, tubulações de esgotamento etc. Para isso foram efetuados estudos sobre as propriedades mecânicas de um compósito de resina poliéster e fibra de bananeira (musa s.p., musácea), nos quais foram retiradas as talas do pseudocaule, sendo feita a fibrilização de forma manual, com o auxílio de uma escova de aço, seguido de secagem ao natural. Após tratamento para limpeza e retirada de cera, a fibra foi cortada em pedaços de aproximadamente $60 \mathrm{~mm}$ a 100 $\mathrm{mm}$ para, juntamente com a resina sintética, fabricar placas de um compósito de características fibrosas com orientação aleatória em relação ao peso da resina. Foram utilizadas três percentagens distintas de fibras (3\%, $6 \%$ e $9 \%$ ), a fim de se efetuar um estudo comparativo entre elas e determinar qual seria aquela com o melhor desempenho mecânico. Foram fabricados corpos de prova de cada material, sendo então submetida aos ensaios de tração uniaxial, flexão em três pontos, absorção de umidade e características térmicas. Os resultados demonstram que, de forma geral, o uso de fibra de bananeira é viável, bastando uma melhoria no seu processo de obtenção (mecanização do procedimento) e um maior cuidado durante a fabricação das peças.

Palavras-chave: Fibra natural. Fibra vegetal. Fibra de bananeira. Compósito híbrido. 


\begin{abstract}
This paper aims to present the feasibility of using a composite using discarded material from the cultivation of banana tree (pseudostem), which is fibrillated together with synthetic resin replacing glass fiber to be used in structural elements that do not demand large mechanical stress such as reservoirs, troughs, domes, sewage pipes etc.. For this, there were studies about the mechanical properties of a composite made with polyester resin and fiber of banana tree (Musa sp, musac), in which the splints were removed from the pseudostem, being made fibrillation by hand, with the aid of a brush steel, followed by natural drying. After treatment for cleaning and removal of wax, the fiber was cut into pieces of approximately $60 \mathrm{~mm}$ to $100 \mathrm{~mm}$, for, together with synthetic resin, make cards of a features fiber composite with random orientation relative to the weight of the resin. We used three different percentages of fiber $(3 \%, 6 \%$ and $9 \%)$, in order to make a comparative study between them and what would be the one with the best performance. Were manufactured specimens of each material and then subjected to uniaxial tensile tests, three point bending, moisture absorption and thermal characteristics. The results show that, in general, the use of banana tree fiber is feasible simply by an improvement in the production process (machining of the procedure) and greater care in the manufacture of parts.
\end{abstract}

Keywords: Natural fiber. Fiber plant. Banana tree fiber. Hybrid composite. 


\section{SUMÁRIO}

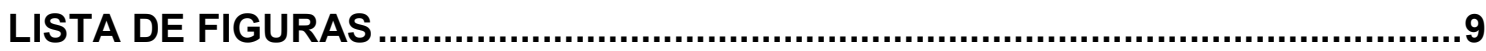

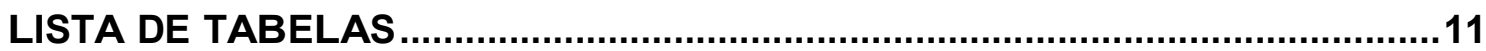

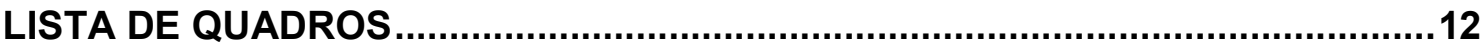

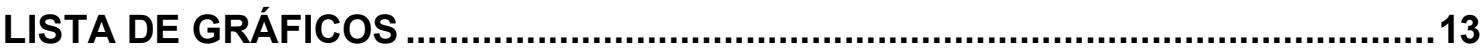

LISTA DE SIGLAS E ABREVIAÇÕES ......................................................14

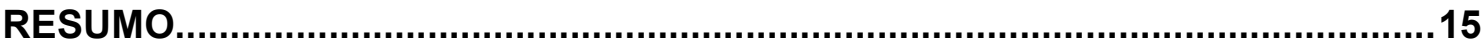

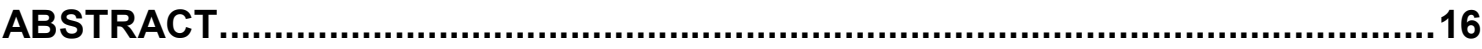

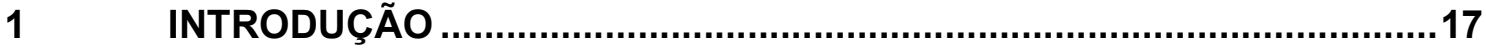

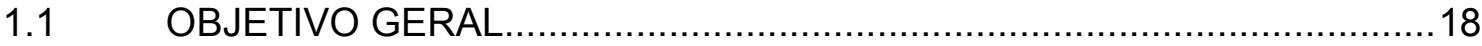

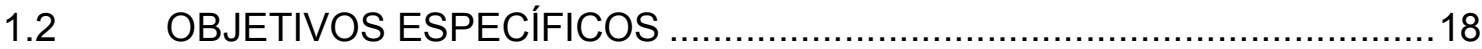

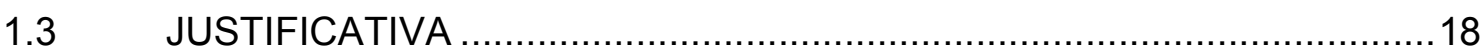

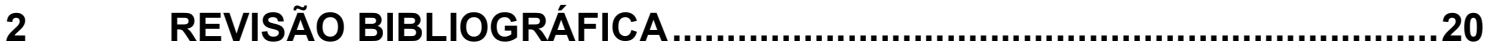

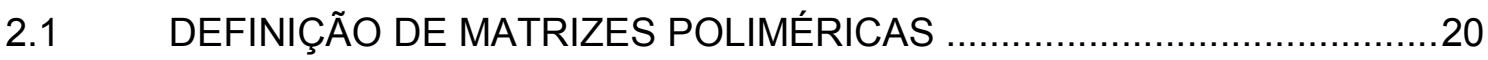

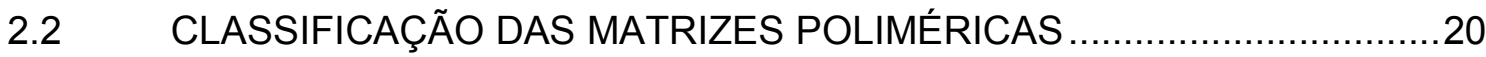

2.2.1 Matrizes Termoplásticas e Termofixas ..................................................21

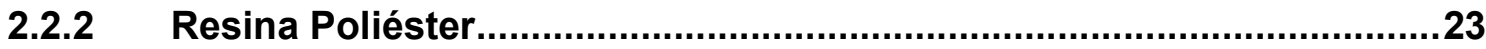

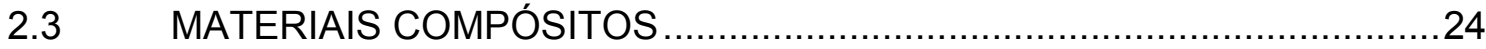

2.3.1 Definições de materiais compósitos .................................................24

2.3.2 Classificações dos materiais compósitos .........................................27

2.3.3 Aplicabilidade dos compósitos .....................................................30

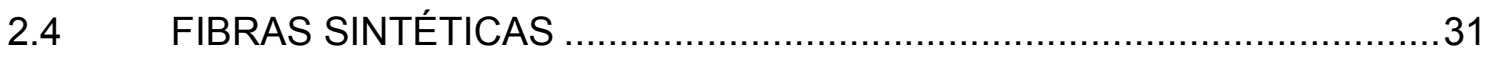

2.4.1 Fibra de vidro ............................................................................... 31

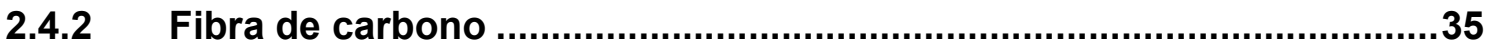

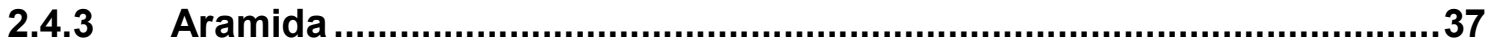

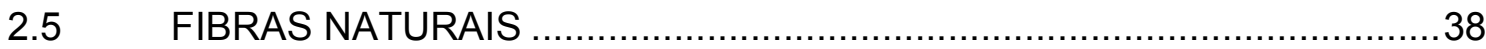

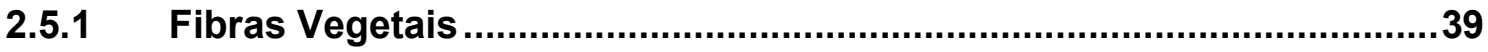

2.5.2 Principais fibras de origem vegetal ...............................................43

2.5.2.1 Fibra de coco.......................................................................... 43

2.5.2.2 Fibra de juta ........................................................................ 44

2.5.2.3 Fibra de curauá .................................................................... 45

2.5.2.4 Fibra de sisal .................................................................. 46

2.5.2.5 Fibra de rami ................................................................. 47 


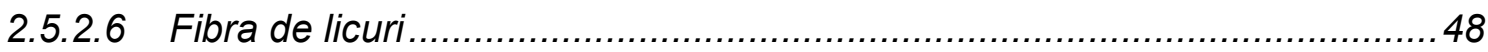

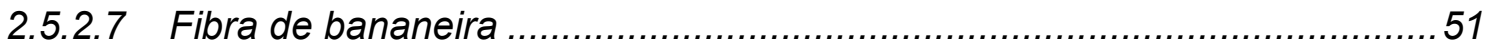

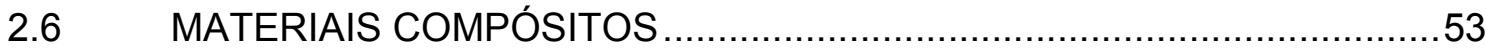

2.6.1 Definições, Classificação e Propriedades dos compósitos ..................53

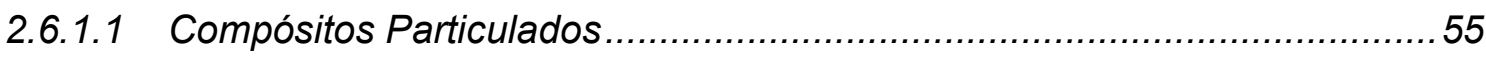

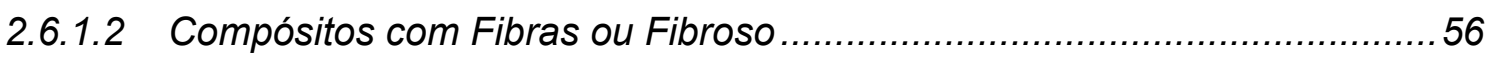

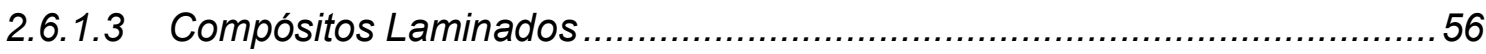

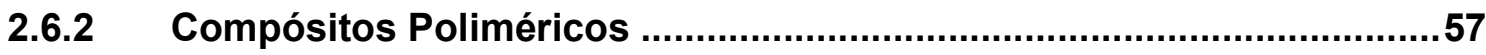

2.6.2.1 Características dos Compósitos Poliméricos .......................................58

2.6.2.2 Compósitos Poliméricos Reforçados por Fibras Naturais ........................59

2.6.3 Influência da interface nas propriedades dos compósitos ...................60

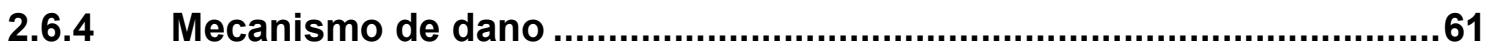

2.6.5 Métodos e processos de fabricação de um laminado............................64

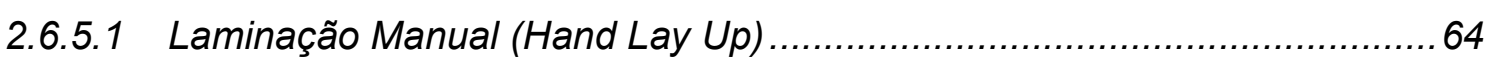

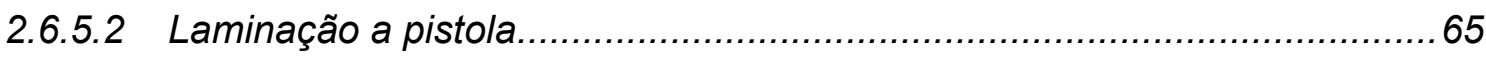

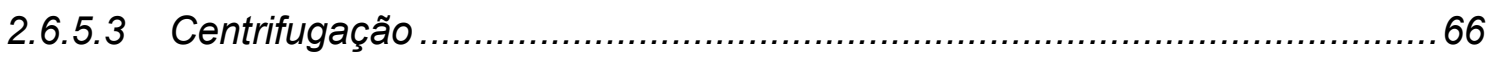

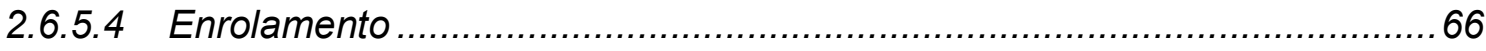

$3 \quad$ MATERIAIS E MÉTODOS

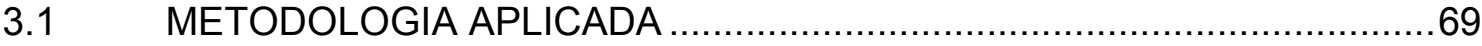

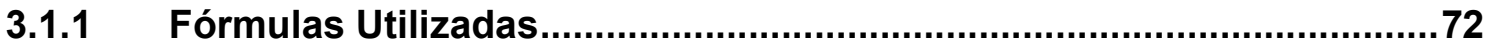

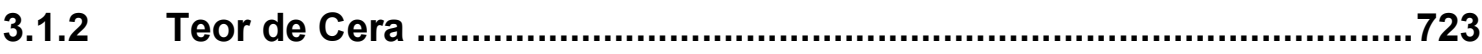

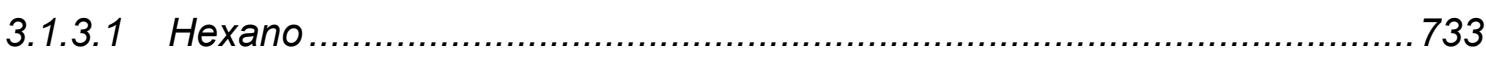

3.1.4 Preparação das placas para a fabricação dos corpos de prova .........744

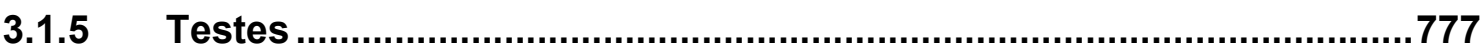

3.1.6 Ensaio de absorção de umidade .....................................................777

3.1.7 Ensaio de tração uniaxial ........................................................................ 80

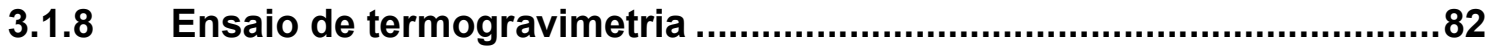

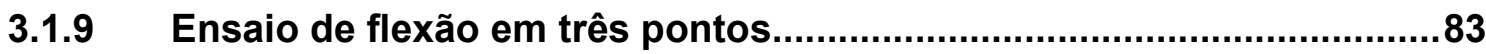

$4 \quad$ RESULTADOS E DISCUSSÃO

4.1 IMAGENS DA MICROSCÓPIA ELETRÔNICA DE VARREDURA PARA AS TRÊS CONCENTRAÇÕES DE FIBRAERRO! INDICADOR NÃO DEFINIDO.5

4.2 MICROSCOPIA ELETRÔNICA DE VARREDURA MEV - 9\% DE FIBRAS

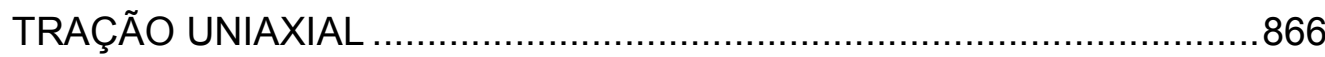


4.4 MICROSCOPIA ELETRÔNICA DE VARREDURA MEV - FIBRAS $6 \% \ldots 888$

4.4.1 MEV - fibra $6 \%$ seca.................................... Erro! Indicador não definido.9

4.5 GRÁFICOS DE RESULTADOS DA ABSORÇÃO DE UMIDADE .............923

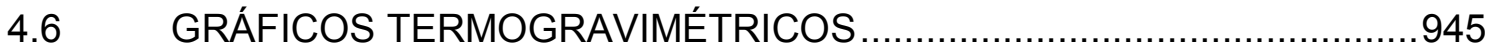

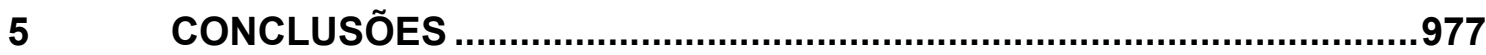

6 SUGESTÕES PARA TRABALHOS FUTUROS ....................................999

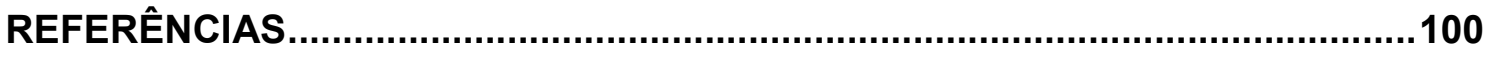




\section{LISTA DE FIGURAS}

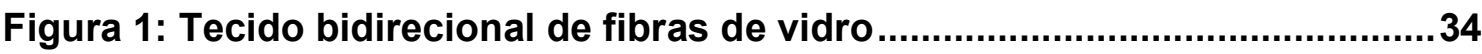

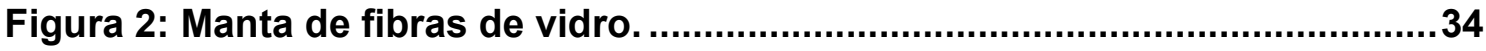

Figura 3: Formas têxteis encontradas para as fibras de vidro...........................35

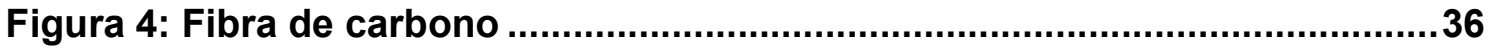

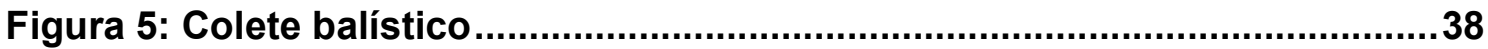

Figura 6: Estrutura da fibra vegetal ..............................................................40

Figura 7: Fibras do bagaço de coco seco....................................................44

Figura 8: Tecido de fibra de juta. ..................................................................45

Figura 9: Fibras de Curauá prontas para impregnação em plástico reforçado.46

Figura 10: Fibras de Sisal ...........................................................................46

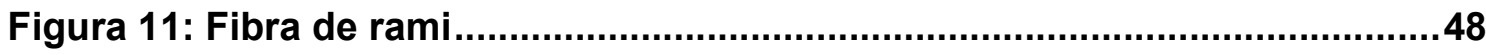

Figura 12: Árvore de Licuri (Syagrus coronata) ...............................................49

Figura 13: Licuri (a) inteiro e (b) descascado ..................................................50

Figura 14: Fibras de Licuri (Syagrus coronata) .............................................50

Figura 15: Esquema geral de uma bananeira com suas diversas partes constituintes ..........................................................................51

Figura 16: Bananeira e suas fibras ..........................................................53

Figura 17: Compósito particulado ............................................................55

Figura 18: Exemplo de arranjo de fibras em matriz para compósito fibroso.....56

Figura 19: Compósito laminado ...............................................................57

Figura 20: Fissuração em matriz polimérica.................................................62

Figura 21: Superfície de fratura de corpos de prova ensaiados em flexão Ruptura das fibras de juta. ..........................................................62

Figura 22: Desaderência fibras de vidro/matriz.............................................63

Figura 23: Delaminação entre as camadas de fibras. ......................................63

Figura 24: Microflambagem em fibras ............................................................64

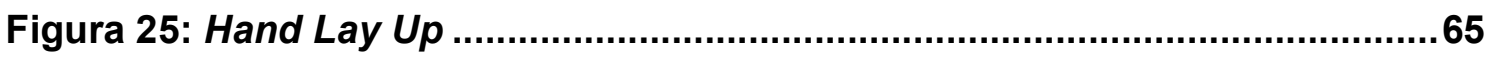

Figura 26: Laminação a Pistola ......................................................................65

Figura 27: Centrifugação ...................................................................................66

Figura 28: Enrolamento ..................................................................................67

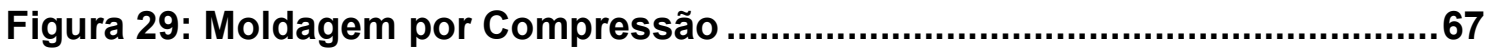

Figura 30: Moldagem por Injeção .................................................................68 
Figura 31: Moldagem por Pultrusão .68

Figura 32: Medição do diâmetro da fibra................................................................70

Figura 33: Preparação das fibras para limpeza de cera (1) ….........................7272

Figura 34: Preparação das fibras para limpeza de cera (2) .................................73

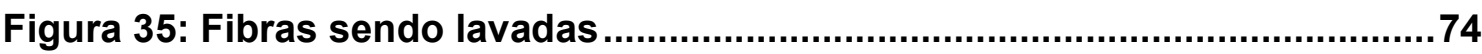

Figura 36: Balança analítica de precisão - Lab. IFBA - Simões Filho .................75

Figura 37: Fresadora tipo Router T- 30

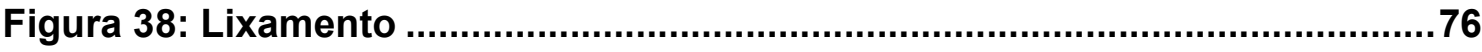

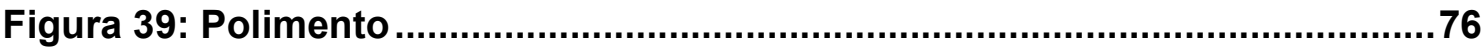

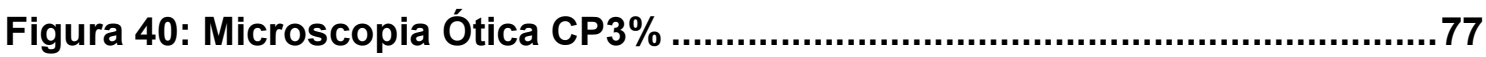

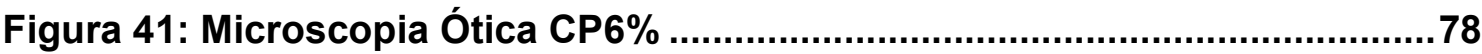

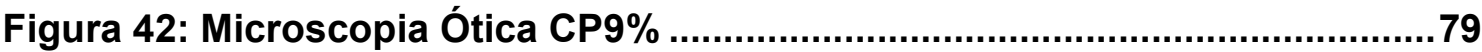

Figura 43: Máquina de Tração SHIMADZU - AG1 ................................................ 81

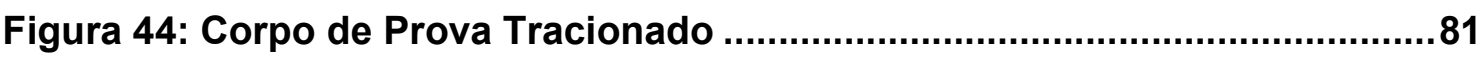

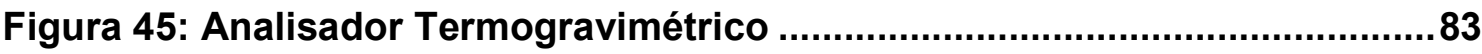

Figura 46: Analisador Termogravimétrico ….....................................................83

Figura 47: Corpo de prova no início do carregamento .......................................84

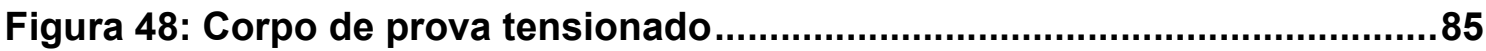

Figura 49: Microscopia Eletrônica de varredura (1) ..............................................85

Figura 50: Microscopia Eletrônica de varredura (2) .............................................. 86

Figura 51: Microscopia Eletrônica de varredura (3) ..............................................86

Figura 52: Microscopia Eletrônica de varredura CP 9\% (1) .................................87

Figura 53: Microscopia Eletrônica de varredura CP 9\% (2) .................................87

Figura 54: Microscopia Eletrônica de varredura CP 9\% …..................................87

Figura 55: Microscopia Eletrônica de varredura CP 3\% ......................................88

Figura 56: Microscopia Eletrônica de varredura CP 3\% (1) ................................88

Figura 57: Microscopia Eletrônica de varredura CP 3\% (2) ................................88

Figura 58: Microscopia Eletrônica de varredura CP 6\% (1) ..................................89

Figura 59: Microscopia Eletrônica de varredura CP 6\% (2) ..................................89

Figura 60: Microscopia Eletrônica de varredura CP 6\% (3) ................................90 


\section{LISTA DE TABELAS}

Tabela 1: Mercado por participação por segmento..........................................31

Tabela 2: Participação do mercado por região.................................................31

Tabela 3: Propriedades mecânicas de fibras vegetais e vidro...........................52

Tabela 4: Diâmetro das fibras de bananeira secas e sem tratamento $(\mathrm{mm})$......70

Tabela 5: Propriedades mecânicas do compósito seco ....................................90

Tabela 6: Propriedades mecânicas do compósito úmido saturado ...................91

Tabela 7: Propriedades mecânicas do compósito seco ....................................92

Tabela 8: Propriedades mecânica do compósito úmido saturado .....................93 


\section{LISTA DE QUADROS}

Quadro 1: Ácidos e glicóis usados na fabricação de resina poliéster. .24

Quadro 2: Classificação dos materiais compósitos segundo a natureza dos

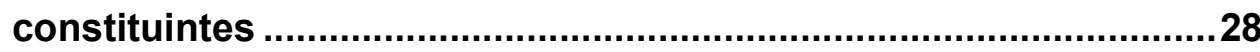

Quadro 3: Classificação dos materiais compósitos quanto à natureza da matriz.

Quadro 4: Classificação dos compósitos quanto à forma, tamanho e distribuição das fibras. ....................................................................29 


\section{LISTA DE GRÁFICOS}

Gráfico 1: Aumento de Peso X Dias (1) ............................................................79

Gráfico 2: Aumento de Peso X Dias (2) .........................................................79

Gráfico 3: Aumento de Volume X Dias (1)................................................... 80

Gráfico 4: Aumento de Volume X Dias (2) ...................................................... 81

Gráfico 5: Gráficos de deflexão (valores médios) .......................................90

Gráfico 6: CP Seco: Força X Deflexão ............................................................91

Gráfico 7: Deformação X Tensão (Valores Médios) ........................................92

Gráfico 8: Deformação X Tensão (Valores Médios) .........................................93

Gráfico 9: Dias X Incremento de Peso (\%) .....................................................94

Gráfico 10: Dias X Incremento de Peso (\%) ...................................................94

Gráfico 11: Dias X Volume..............................................................................95

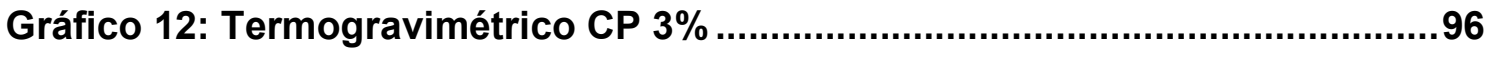

Gráfico 13: Termogravimétrico CP 6\% .............................................................96

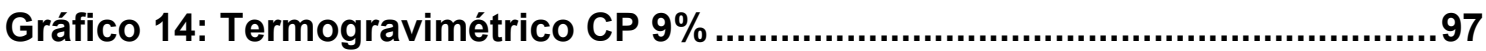




\section{LISTA DE SIGLAS E ABREVIAÇÕES}

\begin{tabular}{ll} 
ASTM & American Socity for Testing and Materials \\
CP & Corpo de prova \\
CPGS & Corpo de prova grande e seco \\
CPGU & Corpo de prova grande e úmido \\
CPPS & Corpo de prova pequeno e seco \\
CPPU & Corpo de prova pequeno e úmido \\
CTGás & Centro de Tecnologia Petróleo e Gás \\
$\square$ & Deformação Longitudinal do Material \\
E & Módulo de Elasticidade \\
F & Força \\
FAO & Organização das Nações Unidas para Agricultura e Alimentação \\
FB & Fibra Bananeira \\
IFBA-SF & Instituto Federal da Bahia - Campus Simões Filho \\
$\sigma$ & Tensão \\
$\square$ & Tensão Cisalhamento \\
UFRN & Universidade Federal do Rio Grande do Norte \\
$\theta$ & Limite Resistência / Resistência Última \\
S & Área transversal \\
T & Tensão \\
P & Modulo de elasticidade na flexão \\
w & Carga \\
\hline
\end{tabular}




\section{INTRODUÇÃO}

Atualmente, com a preocupação crescente com o meio ambiente e a inevitável redução de custos para otimizar a produção e tornar o produto final mais acessível, torna-se imprescindível a utilização de matérias-primas alternativas e com boa aceitação no mercado; neste contexto, novos materiais compósitos a base de resina polimérica e fibras vegetais surgem a cada dia. Tudo isso leva em consideração as propriedades e características desses materiais (alongamento, peso específico, resistência mecânica, estabilidade térmica etc.), pois são determinantes na definição de aplicabilidade, estando diretamente ligadas à matriz, que é a resina, e ao reforço, que é a fibra, sendo que a empregabilidade e aderência destes poderão criar uma interface na qual as propriedades individuais praticamente desaparecem, dando lugar às propriedades que vão caracterizar o compósito.

A aplicação estrutural principalmente em peças de pouca solicitação mecânica vem crescendo de forma singular, o que leva um crescente número de recentes pesquisadores a buscar novos materiais e a aperfeiçoar processos já existentes de obtenção de fibras e modos de fabricação e estruturas das mais diversas. No Brasil, das fibras com maior aceitação no mercado estão as de sisal, curaua, algodão, linho, juta, rami, licuri, bananeira e outras.

Neste contexto, o presente estudo objetiva apresentar a viabilidade da utilização de uma fibra vegetal (bananeira - musácea) em um compósito com resina sintética ortoftálica. A escolha desta fibra se dá pela facilidade de obtenção das mesmas, já que todos os anos várias toneladas do pseudocaule são descartadas após a colheita dos frutos, pois seu aproveitamento é quase nulo ou, mesmo quando utilizado de forma artesanal, não é valorizado ou agrega em si um valor irrisório para o produtor. Logo, este trabalho está abalizado na fabricação de um material em que serão utilizadas fibras secas de bananeira, resina sintética ortoftálica, com as quais foram confeccionados corpos de prova, sendo estes submetidos a ensaios e testes laboratoriais de acordo com as normas, e posteriores testes para comprovações técnicas dos resultados obtidos. 


\subsection{OBJETIVO GERAL}

Apresentar a viabilidade de um compósito utilizando material descartado da lavoura da bananeira (pseudocaule), o qual é fibrilado juntamente com resina sintética em substituição à fibra de vidro, a ser utilizado em elementos estruturais que não demandem grandes esforços mecânicos, tais como reservatórios, calhas, domos, tubulações de esgotamento etc.

\subsection{OBJETIVOS ESPECÍFICOS}

- Desenvolver um compósito com fibras de bananeira;

- Estudar a viabilidade técnica deste compósito;

- Efetuar análise microscópica e macroscópica da fratura;

- Caracterizar termicamente este compósito;

- Determinar as características e propriedades mecânicas deste compósito;

- Dar continuidade aos estudos de materiais compósitos com ênfase em fibras vegetais, criado no Campus de Ensino do Instituto Federal da Bahia - IFBA Simões Filho.

\subsection{JUSTIFICATIVA}

Existe atualmente a real necessidade de se produzir um material mais barato que possa ser utilizado tanto pela indústria de transformação mecânica como pela construção civil e pelo agronegócio (tanques, telhas, palhetas, aletas, carcaças etc.), com uma durabilidade compatível com a dos produtos convencionais. O crescente uso de fibras naturais em substituição ou em composição com as fibras sintéticas tais como as de vidro, carbono, poliéster, poliamida, poliaramida, entre outras, demonstra e reforça a preocupação em se obter materiais que possuam propriedades exigidas sem agredir o meio ambiente. Dentro deste contexto, a fibra de vidro é a que mais vem sendo substituída, por ser de uma utilização mais ampla e de custo relativamente baixo, porém de alta agressividade ao meio ambiente e ao homem. 
O estudo da aplicabilidade das fibras naturais tem a vantagem sobre a primeira em relação à abrasão e tenacidade, chegando a suportar temperaturas de até $180^{\circ} \mathrm{C}$, e sendo utilizada como reforço de resinas em geral. Assim, vem tendo uma aceitação cada vez maior na fabricação de peças e estruturas, principalmente quando não se requer grandes esforços mecânicos das mesmas e principalmente quando não há perigo de choque ou impacto, o que significa dizer que a utilização das mesmas é ideal para peças pequenas e médias.

A bananeira, planta herbácea, cujo nome cientifico é Musa Musaceae paradisiaca, pode ser encontrada em quase todas as partes do mundo, tendo uma produção estimada em aproximadamente 80 milhões de toneladas/ano, segundo a Organização das Nações Unidas para Agricultura e Alimentação (FAO, 2004, apud DONATO et al., 2006). No Brasil, a Bahia ocupa lugar de destaque entre os maiores produtores, sendo que as regiões do Recôncavo, Baixo Sul, Sudoeste e Sudeste constituem-se nas zonas de maiores concentração do cultivo. A bananeira possui um porte de 2,0 a 8,0 metros de altura e um diâmetro médio em sua base de 30 a 45 $\mathrm{cm}$ e na parte superior entre 10 e $15 \mathrm{~cm}$. Suas raízes são fibrosas e superficiais, seu caule é subterrâneo (rizomas) e suas folhas têm bainhas (pecíolos) que, quando justapostos, formam o pseudocaule ou falso caule (que é o foco deste estudo). Sua florescência é de flores masculinas e femininas, podendo haver também flores hermafroditas. Os frutos são as bananas, de vários tipos (maçã, da terra, prata, roxa, nanica, nanicão, d'água) etc., ricas em vitaminas e sais minerais, de alto valor calórico e energético; por serem de baixo custo comercial, são parte integrante do cardápio da alimentação da população de baixa renda, podendo ser consumida in natura, na forma de doce, seca (passa), como aguardente (licor), entre outras. As fibras desta árvore vem tendo atualmente grande utilização na produção artesanal, com a fabricação de bolsas, chapéus, cordas, cortinas, tapetes etc., e em algumas regiões serve também de cobertura para moradias.

Assim, a partir deste estudo, pretende-se dar a oportunidade a comunidades que tradicionalmente utilizam esta fibra de forma artesanal a terem mais uma fonte de renda com o beneficiamento de um resíduo que seria descartado ou queimado, transformando-o em algo muito mais rentável e socialmente aplicável. 


\section{REVISÃO BIBLIOGRÁFICA}

\subsection{DEFINIÇÃO DE MATRIZES POLIMÉRICAS}

A matriz nos materiais compósitos, além de dar a forma ao produto final, tem por finalidade básica atuar como um meio de transferência de carga para os reforços, através da área de contato entre a fibra e a matriz, e proteger o reforço da abrasão mútua, danos e meios de degradação (LEÃO, 2008; CORREIA, 1988).

As matrizes se classificam em: orgânicas (poliméricas), metálicas e cerâmicas. As matrizes poliméricas são as mais utilizadas pela versatilidade de formulação e baixo custo de processamento, quando comparadas com outras matrizes (LEÃO, 2008; VINCENZINE, 1995).

Por reações de polimerização entendem-se aquelas em que substâncias simples (monômeros) reagem entre si, combinando suas moléculas e formando moléculas maiores, caracterizadas pela repetição de uma unidade básica ("mero"). Por essa razão, os produtos desse tipo de reação são também conhecidos como polímeros (LEÃO, 2008; MANO, 1985).

O número de vezes que a unidade básica na molécula do polímero é repetida representa o grau de polimerização. Normalmente, maiores graus de polimerização asseguram melhores propriedades físicas do produto e, por isso, o objetivo da produção de polímeros será o de obter os chamados altos polímeros, para materiais plásticos em geral. Entretanto, ao contrário do que ocorre com os produtos químicos comuns, os polímeros se constituem, na verdade, de uma mistura de moléculas com pesos moleculares variados, estatisticamente distribuídos em torno de um valor médio. Assim sendo, também o grau de polimerização é um valor médio, que dá uma indicação do comprimento médio das moléculas presentes na resina (LEÃO, 2008; MANO, 1985).

\subsection{CLASSIFICAÇÃO DAS MATRIZES POLIMÉRICAS}

Os polímeros podem ter suas cadeias sem ramificações, admitindo conformação em ziguezague (polímeros lineares) ou podem apresentar ramificações 
cujo grau de complexidade pode ir até o extremo da formação de retículos, resultando então no que se denomina polímero reticulado, ou polímero com ligações cruzadas, ou polímero tridimensional. Como consequências imediatas, surgem propriedades diferentes no produto, especialmente em relação à fusibilidade e solubilidade (ODIAN, 1991, apud LEÃO, 2008).

Os ramos laterais dificultam a aproximação das cadeias poliméricas, portanto diminuindo as interações moleculares, acarretam prejuízo às propriedades mecânicas, "plastificando" internamente o polímero (ODIAN, 1991, apud LEÃO, 2008).

Os polímeros podem ser agrupados em função do tipo de reação utilizada em sua obtenção e quanto à técnica de polimerização empregada. Esses fatores afetam significativamente as características dos polímeros produzidos. Existem quatro técnicas industriais empregadas na polimerização de um monômero: a polimerização em massa, em dispersão, em suspensão e em emulsão. Cada uma dessas técnicas possui condições específicas, originando polímeros com características diferentes (BOTELHO, 2006, apud LEÃO, 2008).

Em função do comportamento mecânico, os polímeros são classificados em três grupos (MILLER e BRISTON, 1975, apud LEÃO, 2008, p. 36):

- Borrachas ou elastômeros - possuem longa faixa de elasticidade na temperatura ambiente, baixo módulo e deformações elevadas;

- Plásticos (termoplásticos ou termofixos) - possuem como componente principal um polímero orgânico sintético, tendo usualmente por base resinas sintéticas ou polímeros naturais modificados e são passíveis de receber diferentes formas;

- Fibras - são filamentos que possuem elevada razão entre o comprimento e sua seção transversal, módulo elevado, deformação relativamente pequena.

\subsubsection{Matrizes Termoplásticas e Termofixas}

As características tecnológicas, que impõem diferentes processos tecnológicos, são a base da classificação dos polímeros termoplásticos e termofixos (termorrígidos). Os polímeros lineares ou ramificados, que permitem fusão por 
aquecimento e solidificação por resfriamento, são chamados termoplásticos. Os polímeros que, por aquecimento ou outra forma de tratamento, assumem estrutura tridimensional, reticulada, com ligações cruzadas, tornando-se insolúveis e infusíveis, são chamados termorrígidos (PROGRAMA EDUCAR, 2003).

Os polímeros termoplásticos, sob efeito de temperatura e pressão, amolecem, assumindo a forma do molde. Uma nova alteração de temperatura e pressão reinicia o processo, sendo, portanto, recicláveis. Em nível molecular, à medida que a temperatura é elevada, as forças de ligação secundárias são diminuídas (devido ao aumento do movimento molecular), de modo tal que o movimento relativo de cadeias adjacentes é facilitado quando uma tensão é aplicada. Os termoplásticos são relativamente moles e dúcteis e compõem-se da maioria dos polímeros lineares e são aqueles que possuem algumas estruturas ramificadas com cadeias flexíveis (FIGUEIREDO et al., 2006, apud LEÃO, 2008).

As matrizes termoplásticas possuem como parâmetros de escolha na impregnação dos plásticos, a alta tenacidade, o baixo custo de processamento e temperatura de uso de até $225^{\circ} \mathrm{C}$. Os tipos mais comuns são: o polipropileno, a poliamida (Nylon) e os policarbonatos.

As principais desvantagens do uso das resinas termoplásticas com fase contínua nos compósitos podem ser caracterizadas pela baixa resistência mecânica e baixo módulo elástico, limitando a sua aplicação estrutural (sempre com o uso de fibras curtas).

As principais características que essas resinas podem levar aos seus compósitos são: alta resistência à abrasão e ao ataque químico, elasticidade e tenacidade. A temperatura que afeta as propriedades pode variar de $150^{\circ} \mathrm{C}$ a $170^{\circ} \mathrm{C}$, dependendo do tipo de resina. Pode possuir também alta resistência à chama e ao impacto, baixa resistência ao ataque de solventes orgânicos, tornando-se frágeis e quebradiços (apresentando microfissuras), como no caso dos policarbonatos.

Os polímeros termofixos ou termorrígidos, sob efeito de temperatura e pressão, amolecem, assumindo a forma do molde. Nova alteração de temperatura e pressão não faz efeito algum, tornando-os materiais insolúveis, infusíveis e nãorecicláveis. Durante o tratamento térmico inicial, ligações cruzadas covalentes são formadas entre cadeias moleculares adjacentes; essas ligações prendem as cadeias 
entre si para resistir aos movimentos vibracionais e rotacionais da cadeia a temperaturas elevadas, sendo que o rompimento destas ligações só ocorrerá sob temperatura muito elevadas. Os polímeros termofixos são geralmente mais duros, fortes e frágeis do que os termoplásticos, e possuem melhor estabilidade dimensional (FIGUEIREDO et al., 2006, apud LEÃO, 2008).

As matrizes termofixas podem ser escolhidas para 0 processo de impregnação em função dos muitos parâmetros, tais como: são mais baratas, mais leves e a maioria apresenta certa resistência à exposição ambiental. Os tipos mais comuns são: a resina epóxi, a resina poliéster insaturada e a resina fenólica.

As principais desvantagens dessas resinas são: apresentam comportamento quebradiço, impõem limites no uso pela temperatura, apresentam, em geral, sensibilidade à degradação ambiental devido à umidade e sensibilidade à radiação e oxigenação no espaço.

A sua temperatura de uso pode variar de $180^{\circ} \mathrm{C}$ (epóxi) a $300^{\circ} \mathrm{C}$ (polimida). A principal característica que essas resinas podem levar aos seus compósitos é sua resposta ao calor, já que em geral são isotrópicas, não se dissolvendo ao aquecerlas. No entanto, perdem suas propriedades elásticas à temperatura de distorção térmica. Algumas, como a resina fenólica, têm excelentes características elétricas, boa resistência às altas temperaturas, ao fogo, ao choque, à abrasão, ao ataque químico e a dissolventes orgânicos. Os compósitos a base de resinas poliéster (insaturado) apresentam ampla versatilidade em suas propriedades físicas e mecânicas, já que dependem de constituintes e processo de curado, baixo custo e fácil manuseio e processamento.

\subsubsection{Resina Poliéster}

A resina poliéster constitui uma família de polímeros de alta massa molar, resultantes da condensação de ácidos carboxílicos com glicóis, classificando-se como resinas saturadas ou insaturadas dependendo especificamente dos tipos de ácidos que irão caracterizar a ligação entre os átomos de carbono da cadeia molecular (BLASS, 1988, apud LEÃO, 2008). O Quadro 1 apresenta os ácidos e glicóis usados na fabricação de resina poliéster. 


\begin{tabular}{|l|l|l|}
\hline \multicolumn{1}{|c|}{ Ácidos Insaturados } & \multicolumn{1}{c|}{ Ácidos Saturados } & \multicolumn{1}{c|}{ Glicóis } \\
\hline Maleico & Ortoftálico & Propileno \\
\hline Fumárico & Isoftálico & Etileno \\
\hline \multirow{3}{*}{$\begin{array}{l}\text { Maleico na forma de anidrido } \\
\text { maleico }\end{array}$} & $\begin{array}{l}\text { Hexacloro-endo-metileno- } \\
\text { tetra-hidroftálico (HET ácido) }\end{array}$ & Neopentil (NPG) \\
\cline { 2 - 3 } & $\begin{array}{l}\text { Ortoftálico na forma de } \\
\text { anidrido oftálico }\end{array}$ & $\begin{array}{l}\text { Dihidróxido dipropóxido } \\
\text { bisfenol "A" }\end{array}$ \\
\cline { 2 - 4 } & Dibromoneopentil \\
\hline
\end{tabular}

Quadro 1: Ácidos e glicóis usados na fabricação de resina poliéster Fonte: HOLLAWAY, 1994, apud NEVES, 2006, p. 3.

As resinas poliésteres são classificadas de acordo com o material utilizado na sua fabricação (SILAEX, 2006):

Resina Poliéster Ortoftálica - Mais comum e de uso generalizado;

Resina Poliéster Isoftálica - Aplicada em moldes feitos de fibras de vidro, em tubulações e piscinas;

Resina Poliéster Isoftálica com NPG - Apresenta alta cristalinidade e boa flexibilidade, além de ser resistente a temperaturas elevadas, água natural e às manchas;

Resina Poliéster Tereftálica - Possui resistências físicas pouco superiores a ortoftálica, porém, baixa resistência a UV;

Bisfenólicas - Possui melhores características químicas e térmicas.

\subsection{MATERIAIS COMPÓSITOS}

\subsubsection{Definições de materiais compósitos}

Os materiais compósitos são aqueles que possuem dois ou mais constituintes quimicamente distintos numa escala microscópica, separados por uma interface, sendo muito importante para a especificação destes constituintes. A matriz é o constituinte contínuo, mas nem sempre presente em maior quantidade. O segundo 
constituinte, disperso na matriz, é citado como uma fase de carga ou reforço, que atua aprimorando as propriedades mecânicas da matriz (OLIVEIRA, 2007; MATHEWS e RAWLINGS, 1994).

Oliveira (2007), Hull (1988) e Aquino (2004) definem materiais compósitos como sendo derivados da combinação de dois ou mais materiais (componentes) diferentes quando analisados macroscopicamente ou microscopicamente, cujo objetivo é a obtenção de propriedades específicas e características desejadas, definição também compartilhada por Vlack (1988) e vários outros.

Para Al-Qureshi (1983, apud OLIVEIRA, 2007), materiais compósitos (ou, abreviadamente, compósitos) são materiais de moldagem estrutural (também chamados de materiais de engenharia) feitos de dois ou mais materiais constituintes, com suas próprias propriedades, e que, juntos, resultam em um material com propriedades realçadas ou diferentes das dos materiais originais.

Existem duas categorias de materiais constituintes: matriz e reforço, sendo necessária ao menos uma porção de cada tipo. O material do tipo matriz envolve e suporta os materiais reforços, mantendo-os em sua posição relativa. Os materiais de reforços conferem propriedades físicas (elétricas ou mecânicas) especiais ao todo. Além disso, uma sinergia entre o material matriz e os materiais reforços pode produzir propriedades não disponíveis nos materiais originais.

Outros autores definem compósitos como a combinação heterogênea de dois ou mais materiais, ou seja, aqueles que possuem fases distintas, com o objetivo de se obter propriedades específicas e características desejadas. É certo que tal definição depende do nível de análise do material, pois todos eles podem ser considerados heterogêneos se a escala analisada for muito pequena (OLIVEIRA, 2007; HERAKOVICH, 1997). Pensando desse modo, os compósitos não possuem uma definição criteriosa e, conforme Hull (1987), para um material ser considerado "compósito", no que diz respeito às aplicações estruturais, deve-se considerar os três fundamentos citados abaixo:

- União de dois ou mais materiais fisicamente distintos e separáveis mecanicamente; 
- Podem ser produzidos de modo a ser possível controlar a proporção de cada um dos elementos utilizados para a sua fabricação, objetivandose obter propriedades ótimas;

- As propriedades obtidas no composto são superiores e, possivelmente, únicas, se comparadas aos componentes em separados.

Os principais componentes dos compósitos poliméricos são basicamente dois: o componente estrutural, que pode ser de natureza fibrosa ou pulverulenta, e o componente matricial, que pode ser de natureza termoplástica ou termofixa (OLIVEIRA, 2007; MANO 1991). Como componentes estruturais de reforço podem ser utilizados materiais orgânicos ou inorgânicos, sendo os mesmos de grande importância, pois, além de darem resistência e rigidez ao compósito, podem melhorar, também, propriedades físicas e químicas. A escolha de um reforço é bastante complexa, pois existem variações de tipos, formas e tamanhos, entre outros fatores, podendo ser usado, assim, mais de um tipo de reforço, formando uma combinação híbrida (OLIVEIRA, 2007; FONSECA, 1998).

Os principais requisitos para escolha de um reforço são: melhoria nas qualidades desejadas, baixa absorção de umidade, baixo custo, disponibilidade e compatibilidade com a matriz. Reforços utilizando fibras são os mais utilizados em compósitos poliméricos: fibras de vidro, boro, carbono, kevlar e fibras vegetais, entre outras. Em geral, reforços sintéticos se apresentam sob a forma de fios contínuos, mantas (fios picotados multidirecionais) ou tecidos (fios entrelaçados nas mais variadas formas e espessuras) (OLIVEIRA, 2007; FONSECA, 1998).

As matrizes mais utilizadas são de polímeros sintéticos. O processamento de um compósito de matriz polimérica não envolve, necessariamente, altas pressões e não requer altas temperaturas. Além disso, os problemas associados com a degradação do reforço durante a manufatura são menos significativos para os compósitos com matrizes poliméricas do que para os compósitos com outras matrizes (metálicas, concreto, etc.). Ainda, os equipamentos necessários para se obter compósitos com matrizes poliméricas são simples de usar. Por estas razões, os compósitos com matrizes poliméricas se desenvolveram rapidamente e logo se tornaram aceitos para aplicações estruturais (OLIVEIRA, 2007; MATTHEWS e RAWLINGS, 1994). 
A qualidade da interface entre a matriz e o reforço é fator fundamental no desempenho mecânico do compósito. Para que ocorra interação entre componentes de naturezas químicas diferentes e de quaisquer dimensões ou formas, é essencial a existência de uma área de contato entre elas. Quanto maior for essa área, maior a possibilidade de ocorrer entre os dois componentes uma interação de natureza física, química ou físico-química (OLIVEIRA, 2007; MANO, 1991).

A interface envolve a existência de uma região de transição química e física ou gradiente na fronteira. Em um compósito reforçado com fibras, por exemplo, pode-se dizer que existem três fases: a superfícies da fibra, a interface fibra/matriz e a matriz (YOSOMIYA et al., 1989, apud OLIVEIRA, 2007).

As características da interface dependem da união na interface, da configuração, da estrutura ao redor da interface e das propriedades físicas e químicas dos constituintes. Como resultado, a interface tem uma forte influência na propriedade mecânica do compósito. Em geral, as ligações na interface são descritas em termos de forças intermoleculares e energia livre na superfície. $\mathrm{Na}$ prática, os fatores que influenciam na interação interfacial são: umidade, reação química, adsorção e difusão, camada de tensão residual, morfologia da superfície e efeito da rugosidade (OLIVEIRA, 2007; YOSOMIYA et al., 1989).

Dentre os materiais compósitos de ocorrência natural, podem-se citar os ossos de animais e as madeiras de árvores. Dentre os materiais criados pelo homem, pode-se citar o concreto armado, que é um material compósito de cimento portland e de aço, e a fibra de vidro.

\subsubsection{Classificações dos materiais compósitos}

Os materiais compósitos são usualmente classificados pela natureza dos materiais que os compõem e estão divididos em duas grandes categorias: materiais compósitos naturais e sintéticos, conforme apresentados no Quadro 2. Dentre os materiais compósitos sintéticos, existe ainda uma subdivisão que os classifica em microcompósitos e macrocompósitos (OLIVEIRA, 2007; HULL, 1988). 


\begin{tabular}{|c|c|c|c|}
\hline \multicolumn{3}{|c|}{ NATUREZA DOS MATERIAIS } & EXEMPLOS \\
\hline \multirow{3}{*}{$\begin{array}{c}\text { Materiais } \\
\text { Compósitos }\end{array}$} & \multicolumn{2}{|c|}{ Naturais } & Madeira, osso, músculos \\
\hline & \multirow{2}{*}{ Sintéticos } & Microcompósitos & Plástico reforçado \\
\hline & & Macrocompósitos & Concreto Armado \\
\hline
\end{tabular}

Quadro 2: Classificação dos materiais compósitos segundo a natureza dos constituintes Fonte: Adaptado de HULL, 1988.

Oliveira (2007) e Hull (1988) fazem uma abordagem quanto aos materiais compósitos microcompósitos, tomando como base o tamanho, forma e distribuição das duas ou mais fases. Contudo, a exemplo deste material (plásticos reforçados), pode existir a combinação da alta resistência aliada à grande flexibilidade, na qual se pode exemplificar a alta resistência da fibra ao ser utilizada numa matriz de baixa rigidez, na qual as fibras estão alinhadas na direção do carregamento.

Oliveira (2007) e Hull (1988) explicam ainda que, com o conhecimento básico do comportamento dos materiais de reforço dos compósitos, é possível superar alguns problemas que influenciam no desenvolvimento destes materiais, tais como:

- Quebra da fibra quando utilizada em matrizes termoplásticas;

- Variação das propriedades devido à umidade e variação de temperatura;

- Volume ideal de fibras para a fabricação do produto;

- Projeto do produto para que o mesmo tenha a capacidade de absorver energia;

- Desenvolvimento de materiais com resistência à tração e a corrosão;

- Resistência ao desgaste, entre outras.

Dentro da classe dos materiais microcompósitos poliméricos, os que mais se destacam com relação ao grande número de aplicações estruturais podem ser listados conforme o Quadro 3. 


\begin{tabular}{|c|c|c|}
\hline CLASSIFICAÇÃO & TIPOS DE MATRIZES & $\begin{array}{c}\text { TIPOS DE REFORÇOS } \\
\text { MAIS USADOS }\end{array}$ \\
\hline $\begin{array}{c}\text { Compósitos de matriz } \\
\text { polimérica }\end{array}$ & $\begin{array}{c}\text { Termoplásticas } \\
\text { Termofixas }\end{array}$ & $\begin{array}{c}\text { Fibras de vidro carbono } \\
\text { Fibras de aramida (Kevlar) } \\
\end{array}$ \\
& Fibras vegetais \\
\hline
\end{tabular}

Quadro 3: Classificação dos materiais compósitos quanto à natureza da matriz. Fonte: adaptado de ANTEQUERA, JIMENES e MIRAVETE, 1991.

Segundo Hull (1988), os mais relevantes parâmetros dos microcompósitos são quanto ao tamanho, forma e distribuição dos reforços, como mostrado no Quadro 4.

\begin{tabular}{|c|c|c|}
\hline FORMA & TAMANHO & DISTRIBUIÇÃO \\
\hline Fibras imersas em matrizes & Contínua & Alinhada \\
& Curta & Aleatória \\
\hline Particulados imersos em matrizes & Indefinido & Aleatória \\
\hline Estrutura laminar & Indefinido & Ordenada \\
& & Aleatória \\
\hline Multicomponentes (híbridos) & - & - \\
\hline
\end{tabular}

Quadro 4: Classificação dos compósitos quanto à forma, tamanho e distribuição das fibras. Fonte: adaptado de HULL, 1988.

Al-Qureshi (1983, apud OLIVEIRA, 2007) classifica os materiais compósitos com base na estrutura formada pelos materiais componentes, conforme descrição abaixo:

- Materiais compósitos fibrosos - são materiais nos quais as fibras geralmente são recobertas ou encontram-se unidas por uma matriz, podendo apresentar uma disposição orientada ou aleatória;

- Materiais compósitos laminados - consistem de uma combinação de várias camadas de compósitos. Classificam-se em três tipos: lâminas fortemente aderidas de mesmo material, porém com reforço em uma ou em várias direções, sanduíche e esqueletos (colmeias); 
- Materiais compósitos particulados - são caracterizados por partículas dispersas numa matriz, na qual se podem destacar as seguintes formas: esféricas, planas, elipsoidais, maciças, ocas, entre outros;

- Materiais compósitos híbridos - São materiais que apresentam em sua constituição combinações de vários tipos de reforços, tais como: fibras e partículas, ou vários tipos de partículas ou fibras.

\subsubsection{Aplicabilidade dos compósitos}

Segundo a Associação Brasileira de Materiais Compósitos (ABMACO, 2009), dentre as principais aplicações dos compósitos, podem-se destacar:

Saneamento básico (tubos e estações de tratamento de água e efluentes): segmento com expressiva atuação do setor de compósitos e com grande expectativa de crescimento, uma vez que, até o ano de 2010, a Política Nacional de Saneamento prevê investimentos da ordem de $\mathrm{R} \$ 34$ bilhões.

Transporte (automotivo, ferroviário, marítimo e aéreo): o Brasil é um dos maiores fabricantes mundiais de ônibus, microônibus e vans. Este fato, aliado aos investimentos das montadoras internacionais no país e ao constante crescimento deste segmento, sinaliza um excelente potencial de desenvolvimento para a indústria de compósitos. A destacada atuação do Brasil nos setores de transporte ferroviário e aeronáutico também abre boas perspectivas para as empresas.

Químico e Petroquímico (plataformas de petróleo): 20\% das plataformas de petróleo da Petrobrás já utilizam produtos fabricados a partir de compósitos, substituindo, por exemplo, as grades de piso em aço.

Construção Civil (caixas d'água, tanques, coberturas, perfis, mármore sintético, banheiras, telhas): o compósito já é amplamente utilizado por este segmento e possui um grande potencial de crescimento por se tratar de um setor em franca expansão no Brasil.

Eletroeletrônico (leitos para cabos, antenas, elementos de isolação, cabines telefônicas): as concessionárias de telefonia e energia elétrica já estão utilizando amplamente o compósito em suas obras de manutenção e expansão. 
Lazer (materiais para parques temáticos e piscinas): As empresas fornecedoras de matérias-primas e equipamentos disponibilizam cerca de 430 itens para o setor, como fibras de vidro, resina poliéster, agentes desmoldantes, agentes tixotrópicos, aceleradores, peróxidos e outros, a maior parte fabricada nacionalmente.

Nas Tabelas 1 e 2, percebe-se a participação econômica dos compósitos por segmento e por região brasileira:

Tabela 1: Mercado por participação por segmento

\begin{tabular}{l|c}
\hline \hline Construção Civil & $38 \%$ \\
\hline Transporte & $22 \%$ \\
\hline Distribuição & $19 \%$ \\
\hline Saneamento e Industrial & $9 \%$ \\
\hline Elétrico e telecomunicação & $3 \%$ \\
\hline Náutico & $3 \%$ \\
\hline Vestuário e assessórios & $2 \%$ \\
\hline Outros & $3 \%$ \\
\hline
\end{tabular}

Fonte: ABMACO, 2009.

Tabela 2: Participação do mercado por região

\begin{tabular}{l|c}
\hline \hline Sudeste & $58 \%$ \\
\hline Sul & $28 \%$ \\
\hline Nordeste & $9 \%$ \\
\hline Centro-Oeste & $4 \%$ \\
\hline Norte & $1 \%$ \\
\hline \hline Fonte: ABMACO, 2009.
\end{tabular}

\subsection{FIBRAS SINTÉTICAS}

\subsubsection{Fibra de vidro}

As fibras de vidro ocupam posição de grande destaque na indústria de plásticos reforçados, que as consideram como um dos principais agentes de reforço empregados para obtenção de materiais compósitos. Comercializados para esta finalidade desde a década de 1940, as fibras de vidro têm permitido o uso crescente dos plásticos reforçados em aplicações antes reservadas exclusivamente aos metais e suas ligas. Possuem, também, baixo coeficiente de dilatação térmica e boas propriedades mecânicas, associadas ao seu baixo peso e custo inferior ao de 
algumas fibras, também muito utilizadas nos plásticos reforçados, como as fibras de carbono. As principais características das fibras de vidro, que a tornam tão atraentes, proporcionando vantagens significativas são (CARVALHO, 1992, apud OLIVEIRA, 2007; AQUINO e OLIVEIRA, 2004;):

- Excelente aderência fibra-matriz;

- Boas propriedades dielétricas;

- Baixo custo;

- Alto alongamento na ruptura;

- Facilidade no processamento.

Outras características de destaque são:

- Alta resistência à tração - comparada com outras fibras têxteis, sua resistência à tração específica (por densidade volumétrica) é superior a maioria delas;

- Resistência ao calor e ao fogo - devido à sua origem inorgânica (mineral), as fibras de vidro são incombustíveis. Por seu alto ponto de fusão, estas são indicadas para aplicações em meios com temperatura elevada;

- Resistência química elevada - não sofrem praticamente nenhum tipo de ataque ou degradação por parte dos agentes químicos;

- Resistência à umidade - as fibras de vidro não absorvem umidade, portanto não se dilatam ou desintegram, além de manter em sua máxima resistência mecânicas na presença de umidade;

- Resistência térmica - estas fibras apresentam um coeficiente de dilatação linear térmico muito baixo e um baixo coeficiente de condutividade térmica, a que garante um excelente desempenho em ambientes com variações térmicas bruscas;

- Resistência elétrica - por não serem condutoras, as fibras de vidro são ideais para serem usadas como isolantes elétricos. 
A composição do vidro é um fator determinante nas propriedades das fibras de vidro. A fibra de vidro mais comercializada é a de vidro-E. Sua composição típica e suas respectivas propriedades são descritas a seguir.

Vidro-E: representa mais de $90 \%$ dos reforços nos materiais compósitos de uso geral. Possuem baixo teor de álcali e excelentes propriedades elétricas, além de boas propriedades de resistência, rigidez e desgaste. As fibras de vidro-E são mais baratas que o aço e mais resistentes à corrosão química. Além disso, são mais versáteis porque podem substituir o aço, concreto, alumínio, mármore e outros. As mesmas podem ser aplicadas, ainda, na construção civil, aeronáutica, indústria automobilística, náutica, eletroeletrônica, indústria química, agricultura, pecuária, segurança, móveis, saneamento, lazer, arte e artesanato (SEBRAE-MA, 2002, apud OLIVEIRA, 2007).

Pode-se produzir com ela desde latrinas, banheiras de hidromassagem, caixas d'água, protetores de ar condicionado, fossas sépticas, antenas parabólicas, caixas de correio, portas, janelas e cortinas para a área de construção civil e decoração, passando por placas de circuito impresso, isoladores elétricos, vara de pesca, pranchas de surf, caiaques, barcos, piscinas, escorregadores infantis, carcaças para eletrodomésticos, cadeiras, para-choques automotivos e ainda equipamentos industriais, como tanques para áreas de alto grau de corrosão. As fibras de vidro têm ainda muitas características importantes como, por exemplo, ser isolante elétrico e térmico, resistência ao fogo, alta resistência mecânica e à oxidação, resistência à umidade, baixo custo e peso mínimo (SEBRAE-MA, 2002, apud OLIVEIRA, 2007).

As fibras de vidro, de uma forma geral, se disponibilizam no mercado em formas de: tecidos, mantas e rovings, que podem ser combinadas. Nas formas de tecido e manta, são fornecidas em bobinas e utilizadas na laminação manual. $\mathrm{Na}$ forma de fibras contínuas (rovings) são usadas para laminação à pistola, e outros processos de fabricação, como enrolamento (filament widing), por exemplo.

Tecidos - são constituídos a partir de mechas de fios (roving) de títulos iguais ou diferentes em trama e urdume. Comercialmente são encontradas em dois tipos:

Tecidos unidirecionais - são aqueles em que o número de fios é predominantemente mais elevado em um sentido e os fios estão dispostos em 
paralelo e unidos entre si por fios de dimensões muito pequenas, permitindo a obtenção de elevadas propriedades mecânicas na direção das fibras.

Tecidos bidirecionais - os fios estão dispostos a $90^{\circ}$ uns sobre os outros, na forma de trama e urdume. As Figuras 1 e 2 ilustram as formas mais comuns da utilização da fibra de vidro-E nos plásticos reforçados em geral.

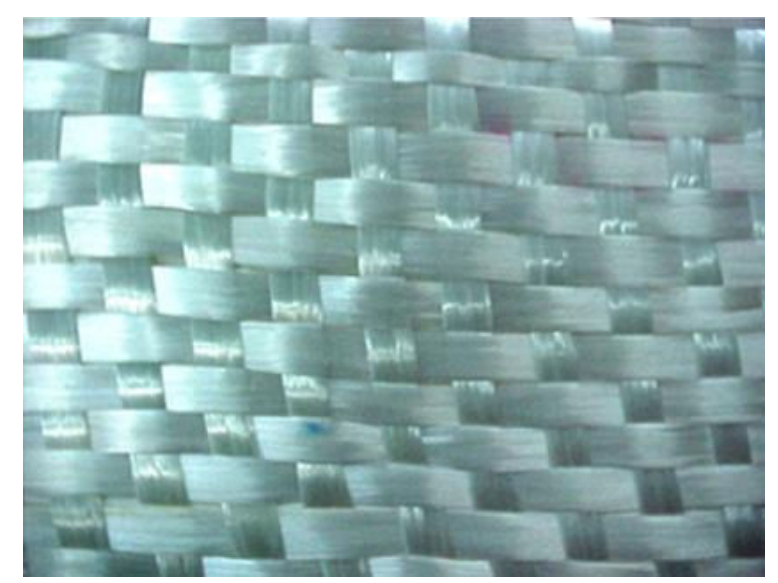

Figura 1: Tecido bidirecional de fibras de vidro Fonte: OLIVEIRA, 2007.

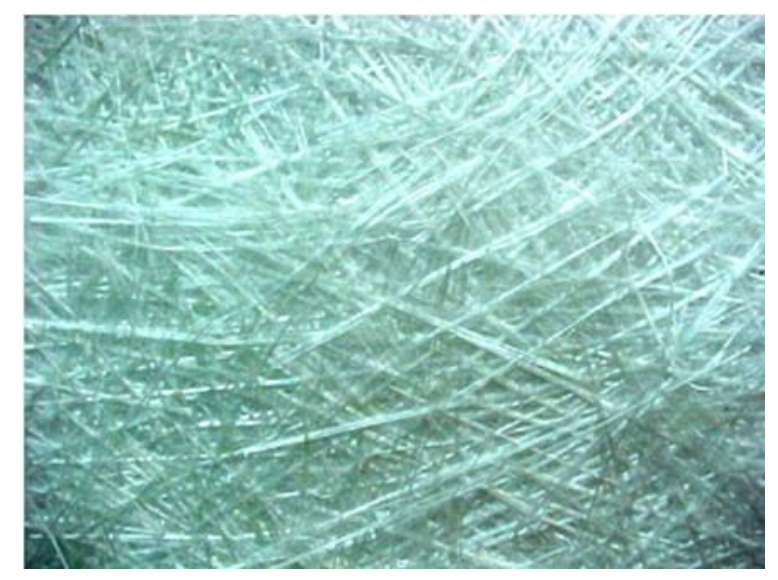

Figura 2: Manta de fibras de vidro. Fonte: OLIVEIRA, 2007.

As características de seleção de um tecido são as seguintes:

- Facilidade de manipulação;

- Regularidade de gramatura e espessura;

- Continuidade do reforço; 
- Facilidade de impregnação.

As fibras de vidro podem ser fornecidas em outras formas como: cordas torcidas, redondas ou quadradas trançadas, gaxetas tubulares, fitas / tecidos. A Figura 3 mostra as formas têxteis encontradas para as fibras de vidro.

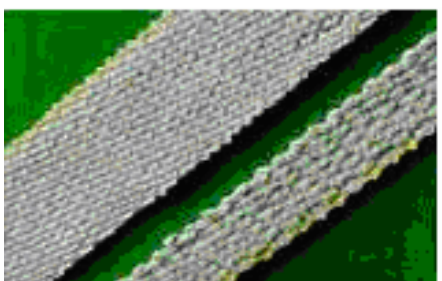

Fitas e tecilos

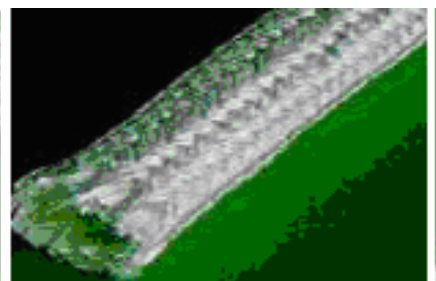

Gaxeta tub ular

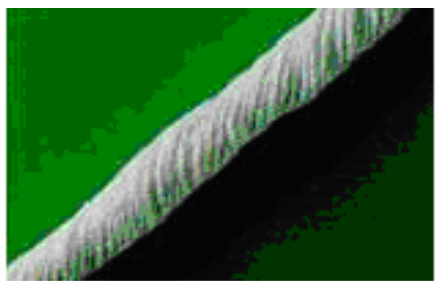

Corda torcid a

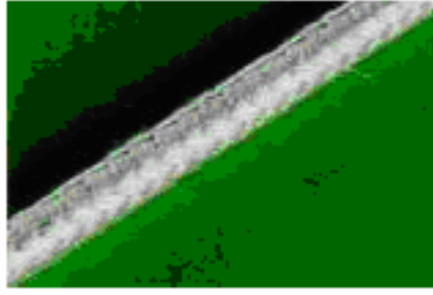

Trançad a red ond a

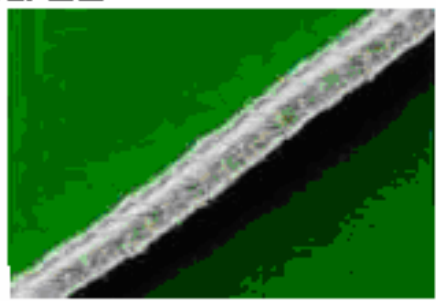

Trançad a quad rada

Figura 3: Formas têxteis encontradas para as fibras de vidro Fonte: ATHENAS ISOLANTES TÉRMICOS, 1998.

\subsubsection{Fibra de carbono}

Pesquisadores das Universidades do Texas (Estados Unidos) e Trinity College (Irlanda) anunciaram a construção de uma nova fibra de carbono mais resistente do que qualquer outra fibra conhecida. Feitas de nano tubos de carbono, um dos mais promissores materiais no reino da nanotecnologia, as novas fibras de carbono poderão um dia viabilizar a construção de tecidos que poderão funcionar tanto como roupas quanto como baterias e sensores. A figura 4 mostra as fibras (escuras) incorporadas em um tecido comum. 


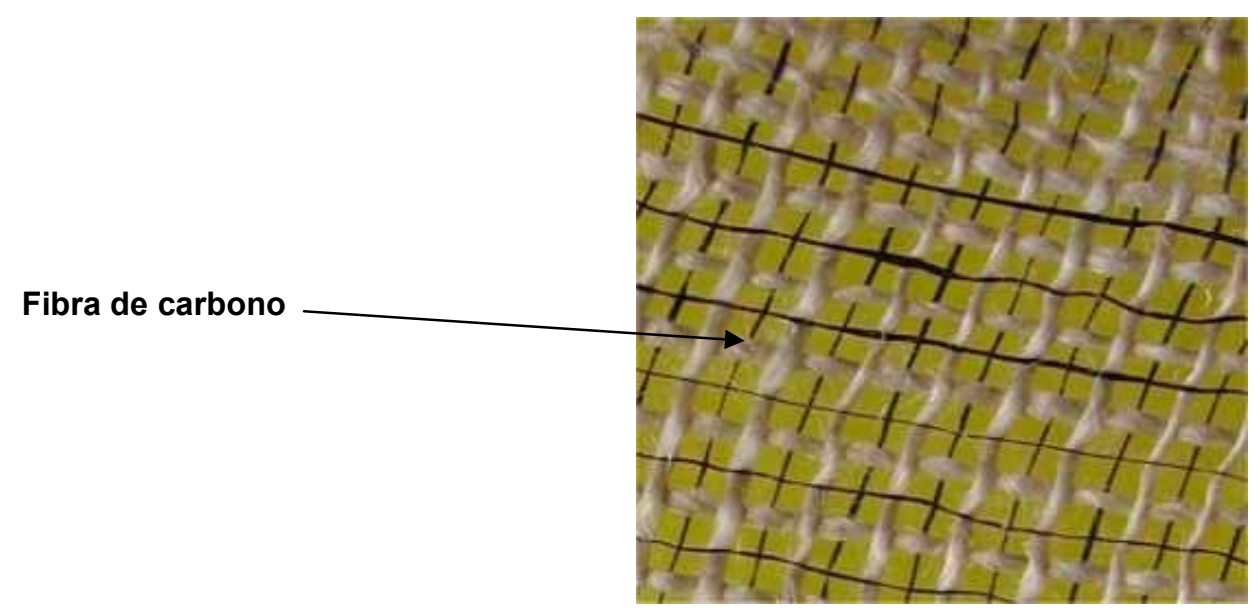

Figura 4: Fibra de carbono

Fonte: INOVAÇÃO TECNOLÓGICA, 2003.

A descoberta, publicada no número de 12 de junho de 2003 da revista Nature e assinada conjuntamente por nove cientistas, poderá criar novos campos de aplicação, como roupas eletrônicas capazes de armazenar energia, viabilizando os "computadores de vestir", músculos artificiais para robótica e melhores vestimentas e coletes à prova de balas (INOVAÇÃO TECNOLÓGICA, 2003).

O processo de construção das super-fibras começa com os nano tubos de carbono, tubos até 50.000 vezes mais finos do que um fio de cabelo, cujas paredes têm espessura de alguns poucos átomos ou mesmo de um único átomo. Os nano tubos são os fios básicos com que é tecida a nova fibra de carbono. A capacidade de absorção de energia dessas fibras super resistentes é quatro vezes maior do que a resistência da seda das teias de aranha e 17 vezes maior do que a resistência do Kevlar, material hoje utilizado em roupas e coletes à prova de balas. É com base nesses comparativos que os cientistas afirmam ser este o material mais resistente já criado. Além disso, as novas fibras de carbono têm o dobro da dureza e da resistência e 20 vezes a tenacidade do aço.

Conforme o Dr. Ray H. Baughman, um dos autores do artigo:

As extraordinárias propriedades mecânicas e eletrônicas dos nano tubos de carbono já são conhecidas há algum tempo. Entretanto, a humanidade não tem tido sucesso ao tentar transformar bilhões dessas nano fibras invisíveis em artigos úteis que possam explorar essas propriedades. Nosso método de tecelagem é o primeiro a produzir fibras de nano tubos de carbono adequadas para uso potencial em uma ampla variedade de aplicações (INOVAÇÃO TECNOLÓGICA, 2003). 
O Dr. Baughman destaca as aplicações que ele acredita serem viáveis para a nova fibra de carbono:

- Tecidos capazes de armazenar energia, da mesma forma que uma bateria, podendo abastecer uma enorme diversidade de dispositivos eletroeletrônicos portáteis;

- Músculos sintéticos capazes de gerar 100 vezes a força de um músculo natural de mesmo diâmetro;

- Sensores capazes de monitorar o movimento e a saúde de doentes em salas de emergência;

- Fontes de energia para naves espaciais em longas viagens, através da conversão de energia térmica em energia elétrica;

- Uma nova geração de coletes à prova de balas e materiais antibalísticos, mais eficientes do que os atuais;

- Fibras multifuncionais para microveículos a ar, dispositivos do tamanho de um inseto que poderão efetuar levantamentos e inspeções de áreas antes de uma invasão militar.

\subsubsection{Aramida}

De acordo com a Companhia Brasileira de Cartuchos (CBC, 2009), as fibras sintéticas de aramida foram desenvolvidas no final da década de 60 e lançadas comercialmente pela DuPont, anos depois, sob a marca KEVLAR ${ }^{\circledR}$. Por sua alta resistência, cinco vezes maior que a do aço, a aramida tornou-se um material de referência na confecção de coletes balísticos. A capacidade de manter sua estabilidade em temperaturas de até $400^{\circ} \mathrm{C}$, além da flexibilidade, elasticidade, leveza e estabilidade química, em comparação com os materiais disponíveis na época em que foi lançada, fez com que a aramida tivesse uma imensa aceitação no mercado.

Com o passar do tempo, novas tecnologias e produtos foram desenvolvidos. As fibras pioneiras de aramida, de elevada gramatura, foram sendo substituídas por novas fibras de aramida, de menor gramatura e maior flexibilidade. Essa evolução levou a indústria a desenvolver novas soluções para a fabricação de coletes 
balísticos, por meio da mistura de fibras e de acordo com características peculiares a cada fibra. Os coletes balísticos confeccionados em aramida têm alta resistência e absorção de energia. O fato de ser um material não inflamável é mais um diferencial oferecido pela aramida (CBC, 2009).

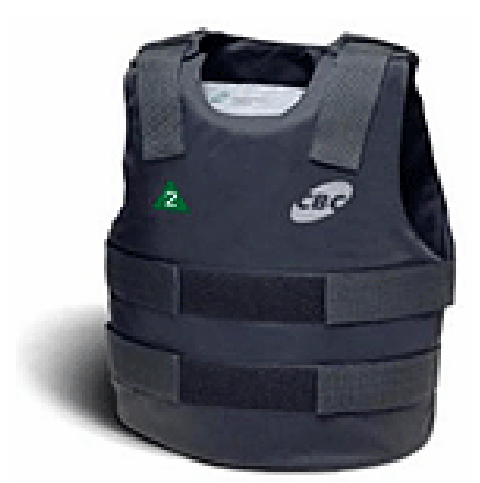

Figura 5: Colete balístico

Fonte: COMPANHIA BRASILEIRA DE CARTUCHOS, 2009.

\subsection{FIBRAS NATURAIS}

As fibras naturais podem ser classificadas em vegetais, animais e minerais. Todas as fibras vegetais, como algodão, juta e sisal têm celulose em sua composição, enquanto fibras de origem animal, tais como lã e seda, consistem basicamente de proteínas.

As vantagens de se utilizar fibras naturais em relação a materiais tradicionais reforçantes, tais como fibras de vidro, talco e mica, são: baixo custo, alta tenacidade, boas propriedades mecânicas e térmicas, redução do desgaste de máquina, facilidade de separação e biodegradabilidade, dentre outras. Já foram relatados na literatura compósitos reforçados com fibra de madeira com propriedades específicas similares aos compósitos de polipropileno com fibra de vidro (FINKLER et al., 2005, apud LEÃO, 2008).

A fibra natural mais utilizada em tecidos é o algodão, composto basicamente de celulose, contendo somente de $3 \%$ a $15 \%$ de material não celulósico. As fibras de algodão representam cerca de $90 \%$ das fibras naturais utilizadas no Brasil (RELATÓRIO MDIC, 2002, apud LEÃO, 2008, p. 22). 


\subsubsection{Fibras Vegetais}

O emprego de fibras vegetais para o reforço de resinas poliméricas não é novo; contudo, houve preferência pelas fibras de vidro e cargas minerais como materiais de reforço com alto desempenho, devido às fibras vegetais possuírem grande volume (baixa densidade aparente), pouca estabilidade térmica e alta absorção de umidade.

$\mathrm{Na}$ última década, porém, o interesse pelas fibras vegetais aumentou novamente, devido ao fato de estas serem provenientes de fontes renováveis, biodegradáveis, recicláveis e representarem uma nova fonte de renda para população rural, além de trazerem economia de energia por meio da redução de peso dos componentes.

Outras vantagens das fibras vegetais em relação aos reforços convencionais (como as fibras de vidro), entre outras, são: baixo custo, baixa densidade, algumas com elevada tenacidade, propriedades aceitáveis de resistência mecânica específica, desgaste reduzido da ferramenta de corte, irritação respiratória reduzida, biodegradabilidade, boas propriedades térmicas, baixo conteúdo energético e uso reduzido de instrumentos para o seu tratamento ou processamento (RANA et al. 2003, apud LEÃO, 2008; NARAYAN et al.,1994, apud PAIVA et al.,1999).

Segundo Young (1997, apud LEÃO, 2008), as fibras vegetais são agrupadas em cinco tipos, dependendo da parte e do tipo de vegetal do qual foi retirada, e podem ser classificadas em:

- Fibras de Gramíneas: retiradas das hastes das plantas monocotiledôneas, tendo como exemplo os cereais (trigo, aveia, cevada, arroz e outros), além do junco, bambu e bagaço de cana.

- Fibras de Folhas: retiradas ao longo do comprimento das folhas, exemplos típicos incluem a abacá, sisal e henequém.

- Fibras de Caule: São de maços retirados do interior da casca (caule) de hastes de plantas, tendo como exemplos, linho, Juta, cânhamo e kenaf.

- Fibras de Sementes e Frutos: Os exemplos mais comuns são o algodão, a paina e a esponja de Luffa cylindrica. 
- Fibras de Madeiras: São fibras provenientes do xilema de vegetais (angiospermas e gimnospermas), tendo como exemplos os eucaliptos, abetuos, pinus, entre outros.

Cada fibra vegetal é constituída de várias fibras elementares fortemente ligadas entre si por um material de cementação, constituído principalmente de lignina. Esta possui uma parede espessa formada por várias microfibrilas que formam espirais ao longo do eixo da fibra, tendo um lúmen no centro. Cada fibra elementar é, em essência, um compósito em que as rígidas microfibrilas de celulose estão envolvidas por uma matriz de lignina e hemicelulose. A lignina atua como o material de cementação, unindo as microfibrilas e a hemicelulose como interface entre a microfibrila de celulose e a lignina (IPT, 1988).

As fibras diferem em sua composição e na orientação das fibrilas (ângulo espiral). Tais características dependem da origem da fibra e são determinantes nas suas propriedades mecânicas. A Figura 6 mostra a estrutura de uma fibra vegetal.

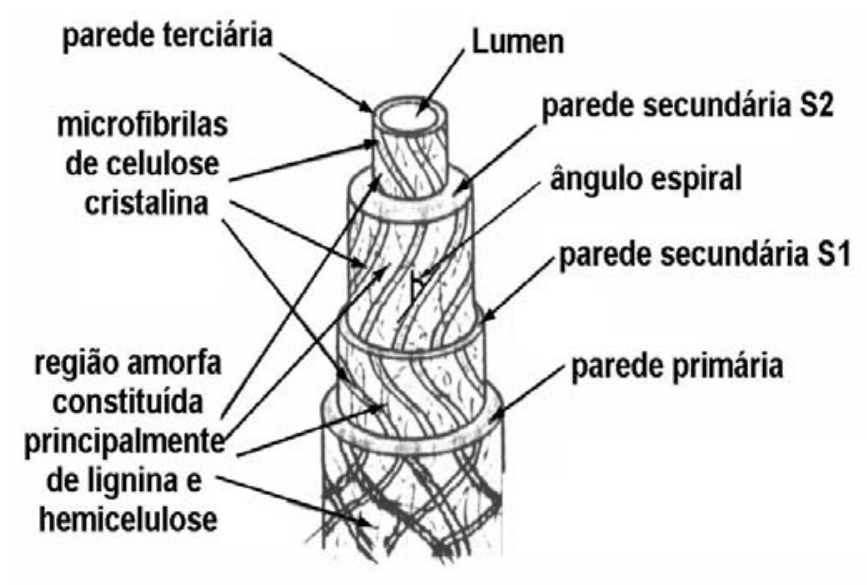

Figura 6: Estrutura da fibra vegetal

Fonte: Banco de dados da BPMCC - DEM/UFRN, 2007.

Os principais componentes químicos das fibras vegetais são substâncias polares, tais como a celulose, a hemicelulose (ou polioses) e a lignina, com menores percentuais de outros componentes como pectina, cera e substâncias solúveis em 
água. A composição química varia ligeiramente de acordo com a região de cultivo, tipo de solo e condições climáticas.

Em geral, o teor de celulose varia entre $60 \%-80 \%$, o teor de lignina em torno de $5 \%-20 \%$, enquanto que outras misturas em cerca de $20 \%$, exceto para algumas espécies de algodão, em que o teor de celulose pode chegar a até 95\% (LEÃO, 2008).

Os constituintes menores incluem compostos orgânicos de diversas funções químicas e, em menor quantidade, os compostos inorgânicos. Os constituintes solúveis em solventes orgânicos, em água, ou ainda em ambos, são normalmente denominados extrativos. Os principais constituintes variam dentro de uma faixa relativamente grande e são dependentes do tipo de fibra.

As propriedades de cada constituinte contribuem para as propriedades como um todo.

Celulose: A mais abundante substância polimérica natural, perfazendo aproximadamente a metade das madeiras, tanto coníferas como folhosas. Sua estrutura é formada por carbono, pontes de hidrogênio e hidroxilas. As forças intermoleculares das pontes de hidrogênio, presentes nos grupos hidroxilas, fazem com que a estrutura cristalina se torne inerte em solventes comuns (LEÃO, 2008; MENDES, 1992, apud FONSECA, 1998);

A celulose, principal componente da parede celular da fibra, é um polissacarídeo linear constituído por um único tipo de unidade de açúcar. É o componente majoritário, perfazendo aproximadamente a metade das madeiras tanto coníferas como folhosas. A celulose pode ser caracterizada como um polímero de alta massa molar, constituído exclusivamente de b-D-glucose, que se liga entre si através dos carbonos 1 e 4, dando origem a um polímero linear (MORRISON e BOYD, 1981; IPT, 1988; FENGEL e WEGENER, 1989; FRAZ e BLASCHECK, 1990, apud LEÃO, 2008).

As moléculas de celulose tendem a formar ligações de hidrogênio intramoleculares (entre unidades de glucose da mesma molécula) e intermoleculares (entre unidades de glucose de moléculas adjacentes). O primeiro tipo de interação é responsável por certa rigidez das cadeias unitárias, e o segundo, pela formação da fibra vegetal. Assim, as moléculas de celulose alinham-se formado as microfibrilas, 
as quais formam as fibrilas que, por sua vez, se ordenam para formar as sucessivas paredes celulares das fibras (SJÖSTRÖM, 1993, apud LEÃO, 2008).

A celulose exibe regiões cristalinas (altamente ordenada) e amorfas (altamente ramificada e desordenada). Materiais gasosos, água e outros líquidos podem penetrar facilmente nas fibrilas e nas microfibrilas devido aos inúmeros capilares e pequenos orifícios encontrados nas regiões amorfas da parede celular. $O$ polímero por si é acessível à água e a agentes químicos através das regiões amorfas e através da superfície das regiões cristalinas (BALÀZSY e EASTOP, 1999, apud LEÃO, 2008).

Hemicelulose: As hemiceluloses constituem uma mistura de polissacarídeos de baixa massa molar que variam entre 25.000 a 35.000 , os quais estão em estreita associação com a celulose e a lignina nos tecidos vegetais. O teor e a proporção dos diferentes componentes nas hemicelulose de madeira e fibras variam grandemente conforme a espécie de árvore. A maior parte das hemicelulose pode ser extraída por tratamento com soluções alcalinas e aquosas. Soluções alcalinas de hidróxido de sódio e potássio são as mais utilizadas para a extração de hemicelulose. A hemicelulose é o componente responsável pela biodegradação, absorção de umidade e degradação térmica da fibra (BROWNING, 1963; FENGEL e WEGENER, 1989, apud LEÃO, 2008).

Lignina: A lignina é uma substância macromolecular componente da madeira, ou seja, um polímero amorfo de composição química complexa que confere firmeza e rigidez estrutural ao conjunto de fibras de celulose, atuando como um agente permanente de ligação entre as células. As moléculas de lignina diferem dos polissacarídeos, por serem constituídas de um sistema aromático composto por unidades de fenil-propano. Há maior teor de lignina em coníferas do que em folhosas e existem diferenças estruturais entre a lignina encontrada nas coníferas e nas folhosas (CHAND et al., 1987, apud LEÃO, 2008; IPT, 1988; FENGEL e WEGENER, 1989).

A maioria das ligninas contém quantidades variáveis de certos ácidos carboxílicos aromáticos na forma de éster. A constituição da lignina não é a mesma em todas as plantas, pois não é uma substância química definida, mas sim uma classe de compostos correlatos. Assim, sua macromolécula não pode ser descrita como uma combinação simples de algumas unidades monoméricas ligadas por 
alguns tipos de ligações, como no caso das celuloses e hemicelulose (IPT, 1988; SJÖSTRÖM, 1993, apud LEÃO, 2008).

Extrativos vegetais: Extrativos são compostos orgânicos (terpenóides, ácidos graxos, flavonóides, esteróides e outros compostos aromáticos) que não fazem parte da parede celular lignocelulósicas. São chamados de extrativos devido à sua facilidade de serem extraídos com água, solventes orgânicos neutros, ou volatilizados a vapor. $\mathrm{Na}$ sua maioria, esses materiais podem ser separados da porção lignocelulósicas por extração com solventes orgânicos e água. Esses constituintes são frequentemente responsáveis por determinadas características da planta como: cor, sabor, cheiro e resistência natural ao apodrecimento (LEÃO, 2008, BROWNING, 1963; BLEDKZI e GASSAN, 1999; LEWIN e GOLDENSTEIN, 1991). Os extrativos compõem uma extraordinária diversidade de compostos e sua ocorrência varia de acordo com a espécie vegetal, ocorrendo nas cascas, folhas, frutos e sementes em quantidades variáveis, porém, quase sempre superiores às encontradas na fibra. O teor de extrativos nas fibras gira em torno de $3 \%-10 \%$ (FENGEL e WEGENER, 1989; IPT, 1988; ROWEL et al., 2000; SJÖSTRÖM, 1993 apud LEÃO, 2008).

\subsubsection{Principais fibras de origem vegetal}

\subsubsection{Fibra de coco}

As fibras de coco são materiais ligninocelulósicos obtidos do mesocarpo do coco (cocus nucifera), e se caracterizam pela sua dureza e durabilidade atribuída ao alto teor de lignina, em comparação às outras fibras naturais. Muito utilizadas em assentos para automóveis, ônibus e caminhões, proporcionam maior conforto que os assentos convencionais, principalmente térmicos, já que esquenta menos, além de ser mais leve.

O reaproveitamento das cascas do coco, de onde são retiradas as fibras, é de suma importância, já que as mesmas são materiais que possuem um tempo de vida útil bastante reduzido, o que contribui para o aumento do lixo sólido, principalmente nos grandes centros urbanos. Assim, é importante o desenvolvimento de novas 
tecnologias que visem à diminuição desse lixo. Outra vantagem é a de ser uma fonte renovável e biodegradável, ao contrário dos produtos utilizados a base de petróleo, como a espuma de poliuretano (GEETHAMMA et al., 1998, apud LEÃO, 2008). A Figura 7 mostra fibras de coco.

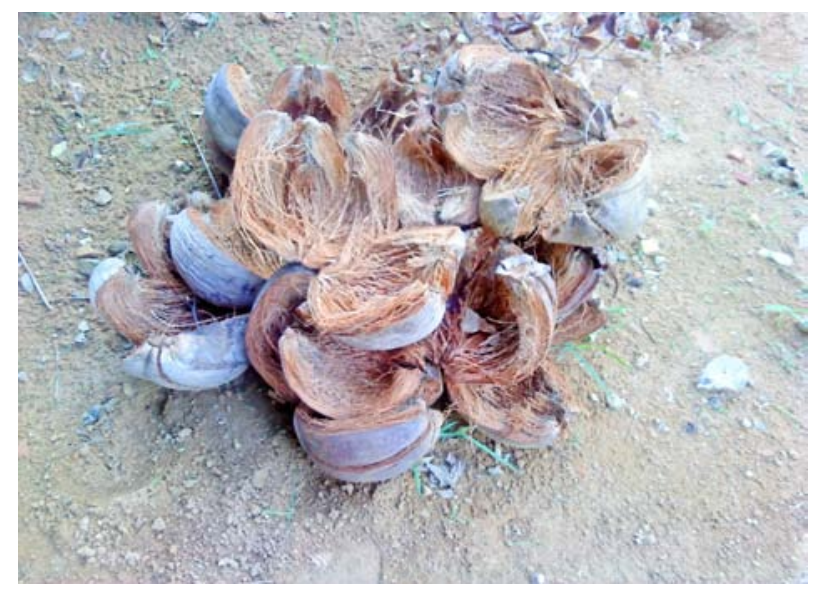

Figura 7: Fibras do bagaço de coco seco.

FONTE : Foto do autor, 2008

A desvantagem desta fibra ainda é o maior preço em relação aos produtos derivados do petróleo.

\subsubsection{Fibra de juta}

A juta é uma planta da família das Filáceas e sua fibra é obtida principalmente das espécies Corchorus, cultivadas em grande escala na Índia e Bangladesh. Planta de clima quente e úmido, necessita de solo fértil e bem drenado para seu desenvolvimento. No Brasil, o seu plantio se dá na região alagadiça da Amazônia, onde encontra água em abundância e altas temperaturas.

Apresentando excelentes propriedades ecológicas, pois é biodegradável e durante seu crescimento controla a erosão, a fibra da juta é considerada longa, variando de 25 até 300 milímetros, sendo utilizada em sacarias, especialmente para armazenamento de produtos agrícolas e bolsas esportivas. No Brasil, são amplamente utilizadas para acondicionamento de batata, café e açúcar, 
principalmente em produtos que serão exportados, sobretudo para países que adotam criterioso controle ambiental (LEÃO, 2008; OLIVEIRA, 1997).

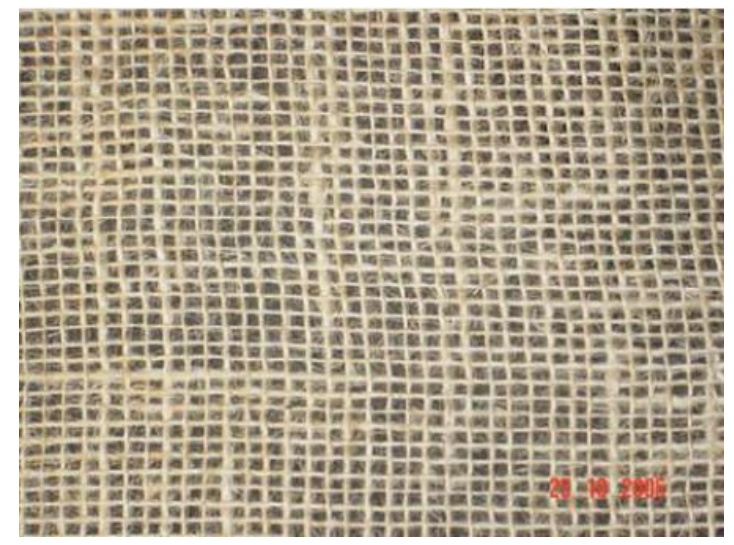

Figura 8: Tecido de fibra de juta.

Fonte: OLIVEIRA, 2007.

\subsubsection{Fibra de curauá}

O curauá é uma planta da família das Bromeliaceas, gênero Ananas e espécie Ananas Erectifolius. Dentre as fibras naturais comumente utilizadas em compósitos poliméricos, a fibra de curauá vem ganhando destaque por ser originária e cultivada na Amazônia, região de destaque nas questões de preservação do meio ambiente, além de apresentar propriedades físicas e mecânicas que superam às das fibras de sisal e juta, mais conhecidas e utilizadas.

As fibras de curauá são originadas das folhas e podem apresentar comprimentos variando de $40 \mathrm{~cm}$ a $60 \mathrm{~cm}$. Os tipos de fibras de cuaruá mais conhecidos são as dos tipos roxo e branco. A Figura 9 mostra as fibras já limpas e "penteadas" e prontas para serem usadas com reforço (AQUINO e SILVA, 2008, apud LEÃO, 2008). 


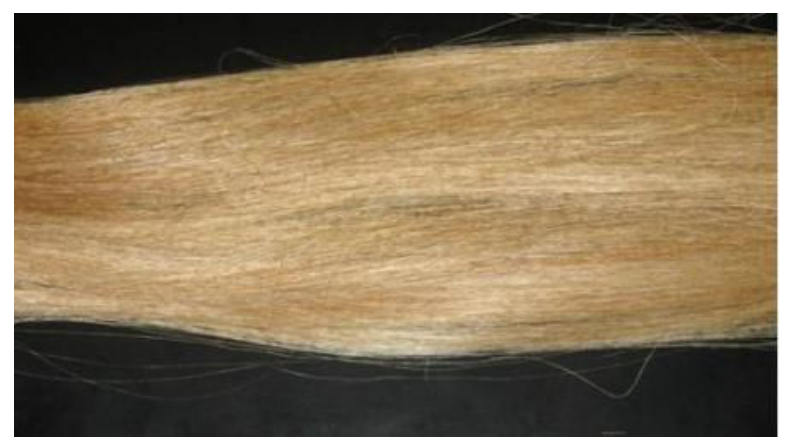

Figura 9: Fibras de Curauá prontas para impregnação em plástico reforçado Fonte: Banco de dados da BPMCC - DEM/UFRN, 2008.

\subsubsection{Fibra de sisal}

A fibra do sisal é retirada da folha de uma planta originária do México, a Agave Sisalana Perrine, sendo atualmente o Brasil o maior produtor do mundo e a Bahia responsável por $80 \%$ da produção nacional. Planta altamente resistente a clima seco e inóspido, pertence à família das fibras longas, as quais variam de 90 $\mathrm{cm}$ a $120 \mathrm{~cm}$. A Figura 10 mostra a fibra do sisal já beneficiada e pronta para comercialização.

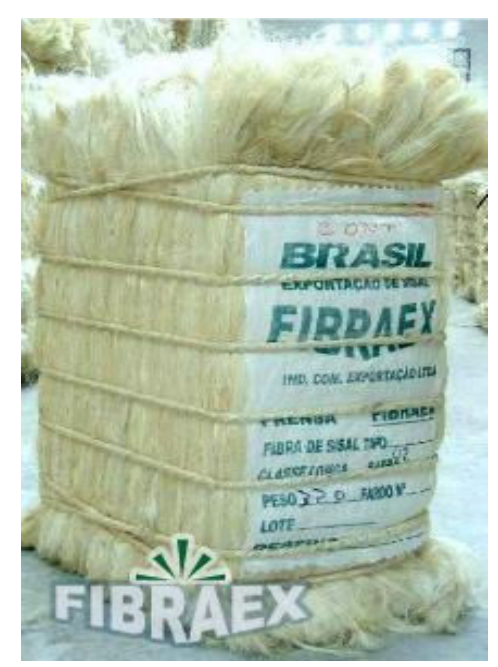

Figura 10: Fibras de Sisal

Fonte: Banco de dados da BPMCC - DEM/UFRN, 2008.

É a fibra vegetal mais dura e resistente que existe. Apesar disso, conforme o site Mecânica On Line (2009), "uma fibra sintética pode demorar até 150 anos para 
se decompor no solo, enquanto a fibra de sisal, em meses torna-se um fertilizante natural". O sisal é muito utilizado para confecção de produtos artesanais tais como bolsas, chapéus, cintos, cortinas, cordas de vários usos, inclusive navais, barbantes para vários tipos de embalagens, tapetes, na produção de estofados, adubos orgânicos, biofertilizantes e sacaria, entre centenas de outros produtos.

A fibra de sisal se destaca entre as fibras foliares em termos de qualidade e de aplicação comercial, e também por possuir um dos maiores valores de módulo de elasticidade. Estudos recentes demonstram que o sisal pode ser utilizado como reforço para polímeros comerciais, tais como o polietileno e a borracha natural (VARGHESE et al., 1994, JOSEPH et al., 1995, apud LEÃO, 2008).

As fibras de sisal são também empregadas na indústria automobilística em substituição à fibra de vidro, tendo como uma das vantagens a maior capacidade de absorção da transpiração humana, o que resulta em maior conforto para os utilitários de veículos automotivos, principalmente os profissionais que passam longos períodos sentados. Empresas como a Mercedes Benz da Alemanha utilizam em seus estofamentos fibras vegetais. Também a utilização do sisal como reforço de peças plásticas na indústria automobilística tem sido bastante satisfatório.

\subsubsection{Fibra de rami}

O rami é uma planta da família da Urticaceae, e sua fibra é oriunda do líber da Boehmeria Nivea e da Boehmeria Tenacissima. Suas fibras pertencem à família das fibras longas, variando entre $150 \mathrm{~mm}$ a $200 \mathrm{~mm}$, apresentando alta resistência, sendo esta três vezes superior à do cânhamo, quatro vezes à do linho e oito vezes à do algodão. A Figura 11 mostra fibras de rami. 


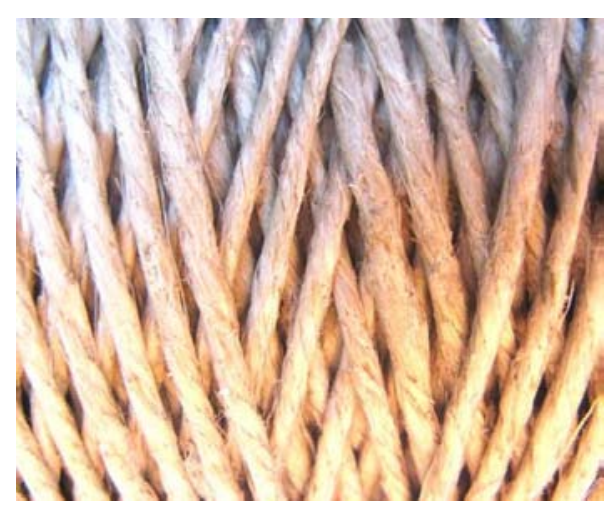

Figura 11: Fibra de rami

Fonte: Banco de dados da BPMCC - DEM Fibra /UFRN, 2008.

A fibra do rami é utilizada na fabricação de tecidos, cordas e barbantes, gerando também, devido a sua resistência, a celulose para a produção de papel moeda. É também usada na fabricação de mangueiras, pneus e fios de paraquedas. Os tecidos feitos de rami são mais ásperos que o linho, porém com a adição de outras fibras sintéticas este problema é minimizado, tornando-o um substituto do linho, pelo seu menor custo (OLIVEIRA, 1997). O Brasil é o terceiro maior produtor mundial, perdendo apenas para a China e as Filipinas, sendo no Paraná a maior concentração da cultura.

\subsubsection{Fibra de licuri}

O licuri (Syagrus coronata) pertence à família das palmáceas (Cocos coronata) e ocorre desde o sul de Pernambuco até o norte de Minas Gerais, abrangendo toda a área oriental e central da Bahia, ocupando também os estados de Sergipe e Alagoas (NOBLICK, 1986, apud LEÃO, 2008) em regiões de serras e vales, sendo seus frutos ricos em cálcio, magnésio, cobre e zinco.

O licuri é uma das principais palmeiras da região semiárida do nordeste do Brasil, de onde é nativo. Segundo Bondar (1938, apud LEÃO, 2008, p. 33) poder-seia mesmo precisar que a palmeira licuri é baiana. Suas folhas também são muito utilizadas para confecção de artesanatos por mulheres e crianças em todo o semiárido baiano. 
Trata-se de uma planta reconhecida na composição da caatinga. Mede de 8 $\mathrm{m}$ a $11 \mathrm{~m}$, tendo folhas com mais ou menos $3 \mathrm{~m}$ de comprimento, pinadas de pecíolo longo com bainha invaginante, e seus folíolos, de coloração verde-escura, estão arranjados em vários planos (LORENZI, 1992, apud LEÃO, 2008). O licuri é essencial na região agreste, pois seus frutos e sementes são comestíveis e formam a base alimentar de muitas aves silvestres. A ararinha-azul-de-lear, por exemplo, é uma das espécies mais conhecidas e preciosas que faz uso desse coquinho. Vivendo no sertão baiano, na região do Raso da Catarina, esse pássaro está ameaçado de extinção - restam apenas cerca de 500 exemplares selvagens - e a sua sobrevivência como espécie está intimamente ligada à existência do licuri (CEMAVE, 2006, apud LEÃO, 2008).

As Figuras 12 e 13 mostram a árvore de licuri (Syagrus coronata) e seu fruto inteiro e descascado.

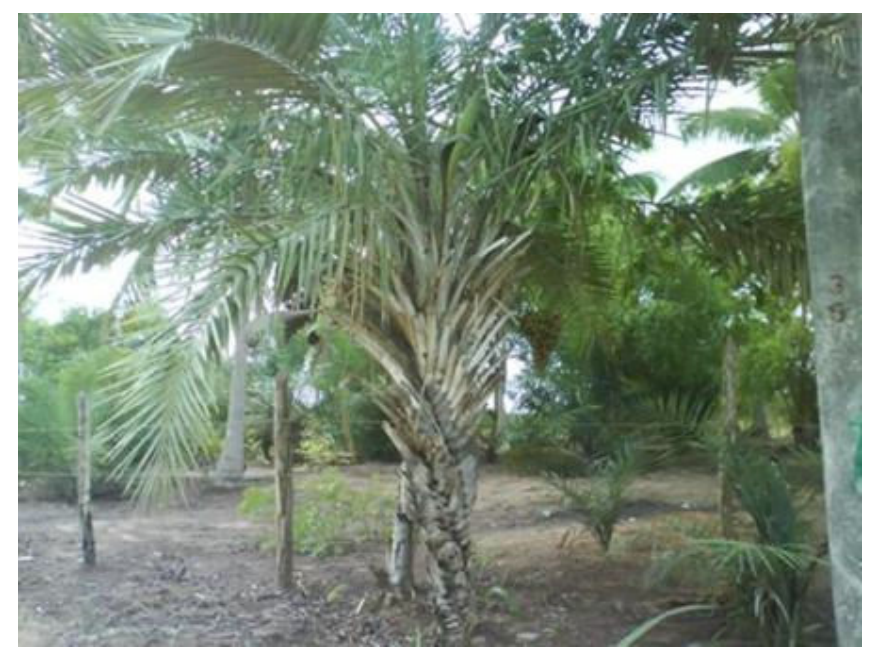

Figura 12: Árvore de Licuri (Syagrus coronata)

Fonte: LEÃO, 2008. 

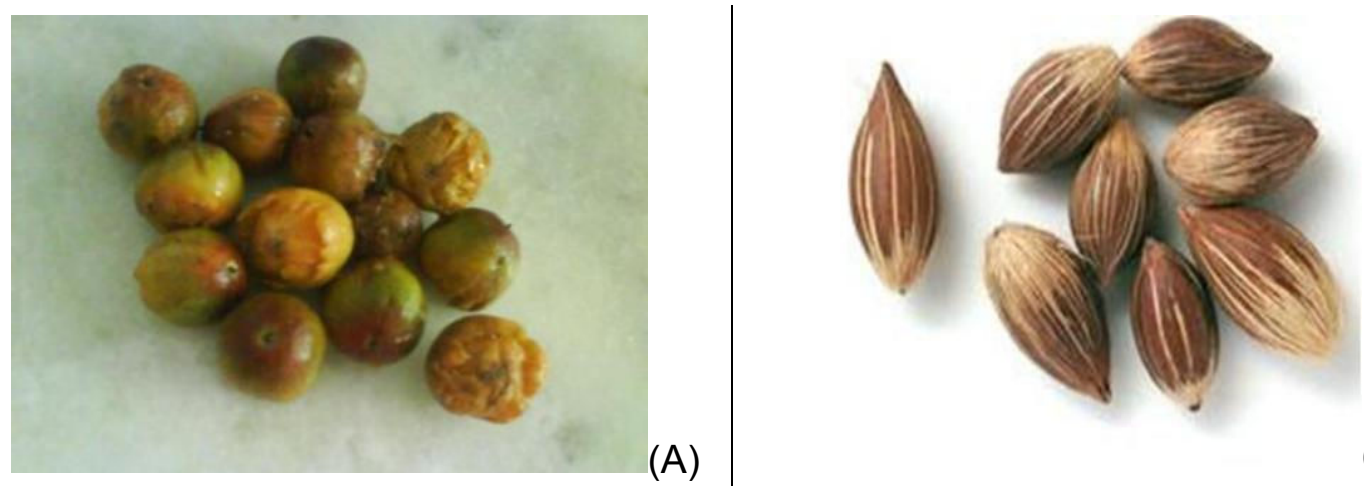

(A)

(B)

Figura 13: Licuri (a) inteiro e (b) descascado

Fonte: (A) Foto do Autor, 2008; (B) LEÃO, 2008.

Apesar de conseguir nascer e crescer sobre o cascalho e de precisar de pouca umidade para sobreviver, ao contrário do que poderia parecer por sua aparência agreste, ocorre naturalmente em solos de boa fertilidade. Segundo Lorenzi (1992, apud LEÃO, 2008), as terras dos sertões são terras boas, que produzem uma grande quantidade de sementes viáveis, disseminadas facilmente por animais silvestres.

A Figura 14 apresenta as fibras do licuri.

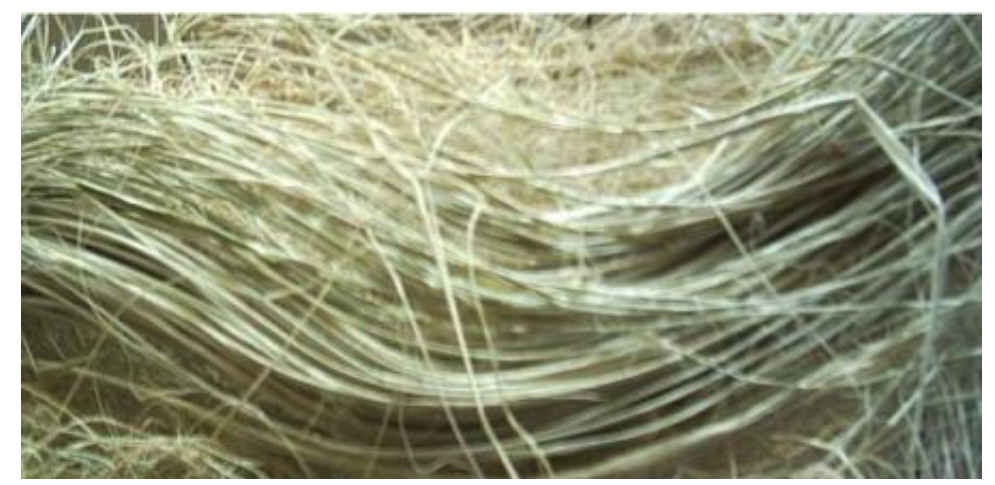

Figura 14: Fibras de Licuri (Syagrus coronata) Fonte: LEÃO, 2008.

Pouca ou nenhuma literatura é encontrada em relação às propriedades de suas fibras, mas sabe-se experimentalmente de sua grande resistência pela utilização das mesmas na confecção de redes de pesca. 


\subsubsection{Fibra de bananeira}

A bananeira, planta muito comum em áreas tropicais e subtropicais, cujo nome cientifico é Musa Musácea, atinge uma altura entre 5 e 7 metros e diâmetro de até $35 \mathrm{~cm}$. Na mata, serve de alimento para vários tipos de animais silvestres, desde macacos até aves. Tem seu cultivo basicamente para a retirada dos frutos que, por serem baratos, saborosos e ricos em vitaminas e sais minerais, fazem parte do cardápio de quase toda a população brasileira, independente de classe. O restante da planta é cortado e descartado quase que na sua totalidade como resíduo. Existe uma infinidade de tipos de bananeiras e todas elas se adaptaram ao tipo de solo e clima do Brasil, portanto é muito comum o plantio desta árvore em todo o estado da Bahia.

Na Figura 15 vê-se um esquema geral de uma bananeira com suas diversas partes constituintes.

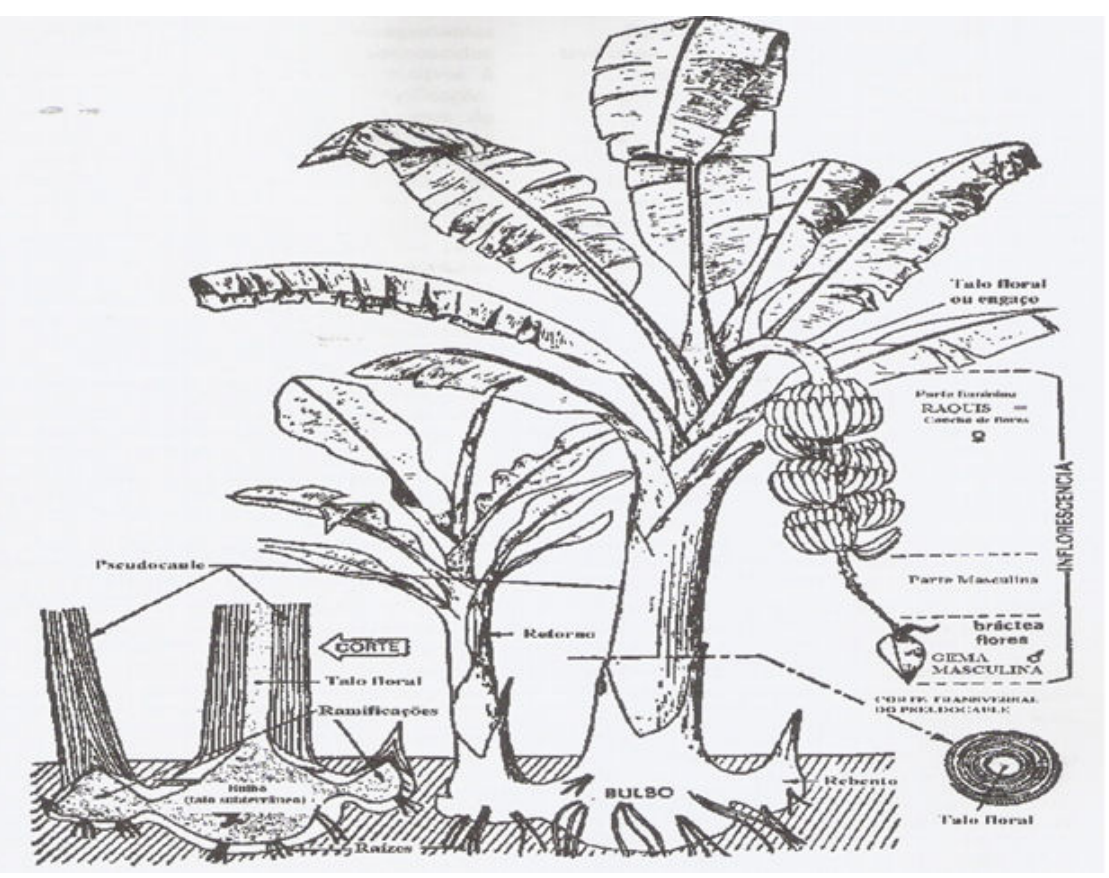

Figura 15: Esquema geral de uma bananeira com suas diversas partes constituintes Fonte: CHAMPION, 1968, apud COELHO, MATA e BRAGA, 2001, p. 23.

As fibras com as quais estamos trabalhando são obtidas do pseudocaule da bananeira, e possuem características similares às demais fibras (cf. Tabela 3), tendo se tornado objeto de estudos por diversos pesquisadores nacionais e internacionais, 
objetivando sua aplicabilidade funcional na indústria de transformação mecânica, na construção civil, no agronegócio, na indústria náutica, entre outras.

Para a extração das fibras, o pseudocaule é cortado e desfiado com o auxílio de uma escova de aço, no qual é separado o que podemos chamar de parte liquida (caldo), um emaranhado de fibras que gruda na escova e pode ser aproveitado em outro trabalho, e as fibras propriamente ditas, que são lavadas em água corrente e colocadas para secar ao ar livre. Essas fibras, após secas e em boa quantidade, são fervidas por um período de 30 minutos e colocadas para secar ao ar livre mais uma vez, para logo depois serem levadas para um tratamento químico a fim de reforçar a retirada da cera, que é comum a todas as fibras, fator que confere melhor molhabilidade no momento de confeccionar o compósito - o que afeta a adesão fibra-matriz.

$\mathrm{Na}$ Tabela 3, é possível observar as propriedades mecânicas das fibras vegetais, comparando-as com a fibra de vidro, dando-se destaque à fibra de banana. Em seguida, nas Figura 16, vê-se a planta e suas fibras.

Tabela 3: Propriedades mecânicas de fibras vegetais e vidro

\begin{tabular}{|c|c|c|c|c|c|c|}
\hline Fibras & $\begin{array}{c}\text { Densidade } \\
\left(\mathrm{g} / \mathrm{cm}^{3}\right)\end{array}$ & $\begin{array}{c}\text { Resistência } \\
\text { À Tração } \\
\text { (MPa) }\end{array}$ & $\begin{array}{l}\text { Módulo } \\
\text { à Tração } \\
\text { (GPa) }\end{array}$ & $\begin{array}{c}\text { Alongamento } \\
\text { Máximo } \\
(\%)\end{array}$ & $\begin{array}{c}\text { Resistência } \\
\text { à Tração } \\
\text { (MPa) }^{*}\end{array}$ & $\begin{array}{l}\text { Módulo } \\
\text { à Tração } \\
\text { (GPa)* }^{\text {(GPa) }}\end{array}$ \\
\hline $\begin{array}{c}\text { Fibra de } \\
\text { vidro }\end{array}$ & 2.6 & 1750 & - & 2.1 & 2000 & 70 \\
\hline Linho & - & - & - & - & 390 & 26 \\
\hline Linho batido & 1.4 & 195 & 22.3 & 1.2 & - & - \\
\hline Linho verde & 1.4 & 337 & 29 & 1.3 & - & - \\
\hline Cânhamo & - & - & - & - & 580 & 13 \\
\hline $\begin{array}{c}\text { Cânhamo } \\
\text { batido }\end{array}$ & 1.4 & 295 & 16.3 & 1.1 & - & - \\
\hline $\begin{array}{c}\begin{array}{c}\text { Cânhamo } \\
\text { verde }\end{array} \\
\end{array}$ & 1.4 & 173 & 7.5 & 1.9 & - & - \\
\hline Sisal & 1.3 & 126 & 3.8 & - & 835 & 37 \\
\hline Coco & 1.2 & 149 & - & 23.8 & - & - \\
\hline Rami & 1.4 & 393 & 7.3 & 1.8 & 900 & 24 \\
\hline Banana & 1.2 & 74 & 2.2 & 3.2 & 914 & 32 \\
\hline
\end{tabular}

Fonte: SCHUH e GAYER*, 1997, apud SILVA, 2003. 

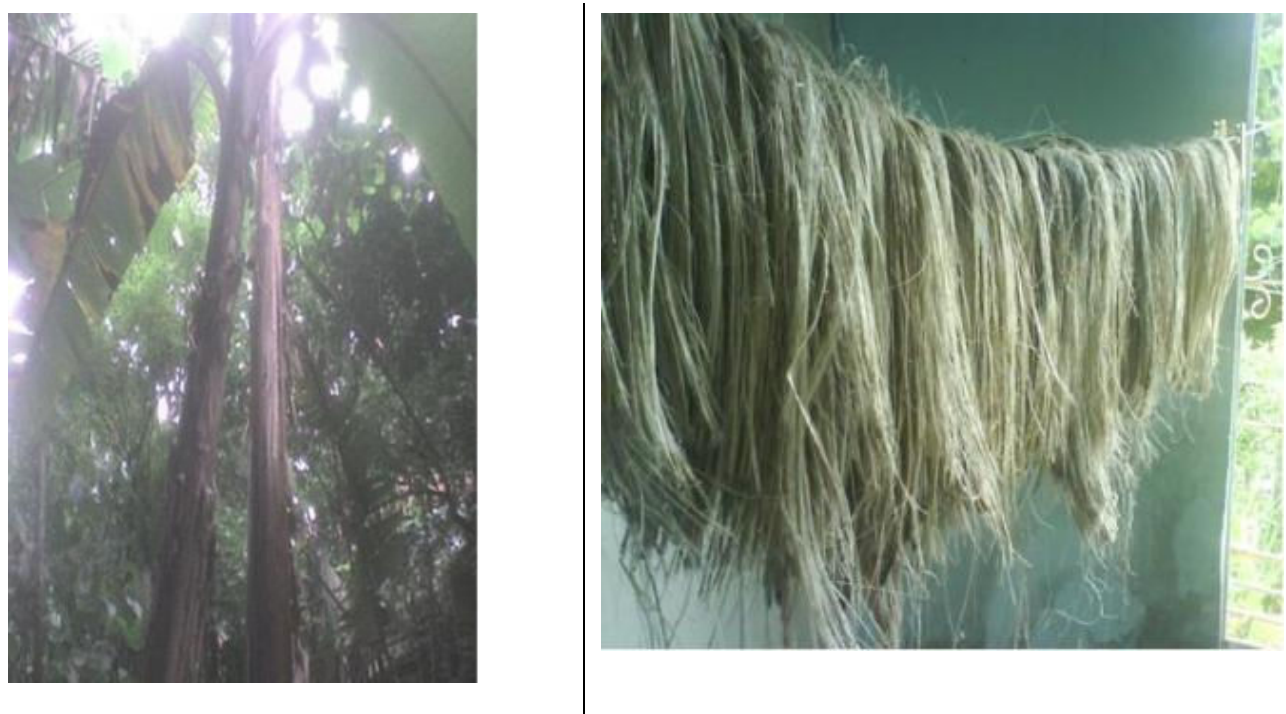

Figura 16: Bananeira e suas fibras

Fonte: Fotos do autor, 2009.

Resta afirmar que várias indústrias fornecedoras de peças plásticas para as montadoras de automóveis, ônibus e caminhões já vêm utilizando fibras vegetais em suas formulações, dentre os quais se destacam fibras vegetais nas seguintes peças: revestimentos internos da cabina (teto, parede traseira e portas), apoio de cabeça e encosto de banco, para-sol externo, painel de instrumentos, bolsa de ferramentas, encapsulamento de cabina/motor e para-choque (MORASSI, 1994, apud LEÃO, 2008).

\subsection{MATERIAIS COMPÓSITOS}

Esta subseção constará da terceira e última etapa da pesquisa bibliográfica e se refere a um dos temas específicos nesse trabalho de investigação que é a utilização dos materiais compósitos poliméricos em suas variadas formas estruturais e constituições.

\subsubsection{Definições, Classificação e Propriedades dos compósitos}

O uso de materiais compósitos, ou seja, materiais formados a partir da combinação de dois ou mais constituintes individuais têm alcançado cada vez mais 
espaço em vários segmentos da indústria. Esta crescente utilização deve-se ao fato de que os materiais compósitos possibilitam uma boa sinergia na interação entre os diferentes componentes que o formam, oferecendo melhores características estruturais para determinadas aplicações que seus constituintes não ofereciam individualmente. Somem-se a isto os fatores econômicos e ambientais que dificilmente seriam alcançados com algum outro material não compósito (HAGE JÚNIOR, 1989).

Os compósitos para aplicações mais sofisticadas só apareceram em larga escala na primeira metade do século XX, com a chegada da produção comercial de resinas plásticas. No início, utilizou-se fibra natural como reforço: madeira, tecidos, serragem, etc. Em 1940 passou-se a utilizar compósitos com matriz polimérica reforçados por fibras de vidro e isso deu origem à era dos compósitos avançados. $O$ que se observa é que períodos pós-guerra resultam em incremento do desenvolvimento tecnológico e foi isso o que aconteceu com a utilização dos compósitos, que teve o seu avanço depois da Segunda Guerra Mundial, passando a serem bastante utilizados nas indústrias aeroespacial, aeronáutica, automobilística, naval e eletroeletrônica (LEÃO, 2008).

Segundo Leão (2008, p. 40),

O principal objetivo da preparação de materiais compósitos é imprimir novas propriedades aos materiais, principalmente no ponto de vista do comportamento mecânico, como aumento de resistência mecânica aliada a diminuição do peso. Um exemplo é o concreto que resiste bem a compressão, mas tem baixa resistência à tração, entretanto ao formar um compósito com o aço passa a ter boa resistência à tração. A adoção e a importância da utilização de materiais combinados reportam-se a História da humanidade, como fabricação de tijolos no antigo Egito e de espadas medievais. O novo material obtido deverá possuir uma estrutura com características homogêneas na análise macroscópica.

Os compósitos são materiais de moldagem estrutural, constituídos por uma fase contínua conhecida como matriz e que abrange três tipos: cerâmica, polimérica e metálica; e por uma fase descontínua ou dispersa chamada de reforço, de carga ou de agregado, dependendo do tamanho ou do formato de suas partículas. $\mathrm{Na}$ natureza também encontramos materiais compósitos, como é o caso da madeira que é constituída por fibras de celulose (fase descontínua) envolvida por uma matriz (fase contínua) de lignina. Por ser um material constituído de várias fases, além das 
propriedades de cada constituinte, o compósito apresenta ainda propriedades intermediárias decorrentes da formação de uma região interfacial.

A adesão de um material a outro está associada ao estabelecimento de interações que podem ser dos tipos: eletrostáticas, ligações de hidrogênio, ligações covalentes ou forças de Van der Walls. A natureza destas interações está associada à afinidade química entre a matriz e a fase dispersa. Geralmente as cargas (fase dispersa) apresentam natureza hidrofílica enquanto que o polímero (matriz) tem natureza hidrofóbica (NETO, 2006; apud LEÃO, 2008).

Quanto à classificação dos compósitos, a literatura apresenta vários tipos de acordo com o tipo dos materiais constituintes e dos processos de fabricação. Um desses tipos de classificação define compósitos em termos da morfologia de seus agentes de reforço: compósitos particulados, com fibras ou fibroso e laminados.

\subsubsection{Compósitos Particulados}

Trata-se da imersão de partículas de um ou mais materiais em uma matriz de composição. A Figura 17 mostra um exemplo de compósito particulado:

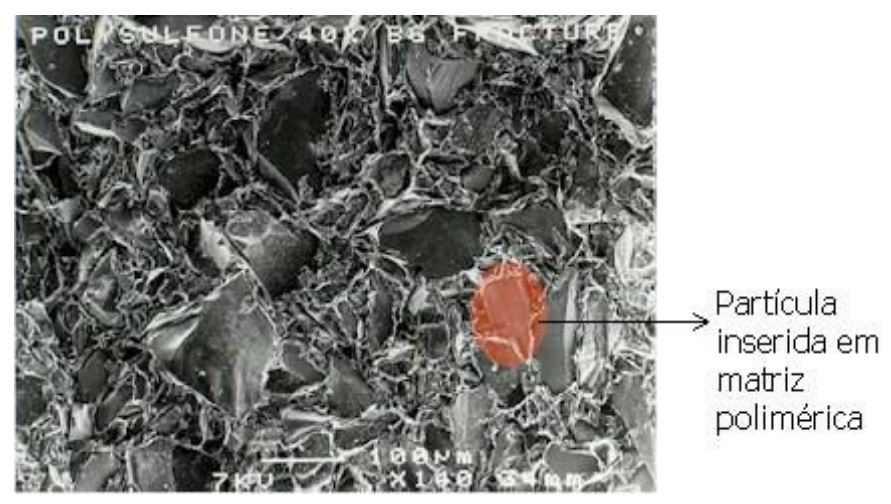

Figura 17: Compósito particulado Fonte: LEPC - UFMG, 2007. 


\subsubsection{Compósitos com Fibras ou Fibroso}

São constituídos por uma união de fibras longas ou curtas em meio de uma matriz atuante, como material de reforço. $O$ arranjo das fibras pode ser unidirecional ou em várias direções (aleatório). A Figura 18 mostra exemplo de arranjo de fibras em matriz para compósito fibroso.

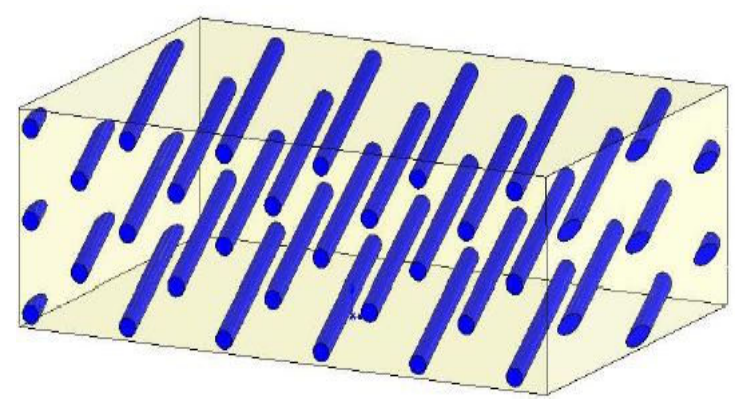

Figura 18: Exemplo de arranjo de fibras em matriz para compósito fibroso Fonte: GUIMARÃES, 2006, p. 23.

\subsubsection{Compósitos Laminados}

Laminação de diferentes camadas, de materiais distintos, combinando suas características mecânicas. Existem vários exemplos desta classe de material como laminados bimateriais, ou estruturas "sanduíche", em que o núcleo mais macio é coberto com chapas de maior resistência mecânica. Consegue-se atingir uma alta resistência à flexão nessas estruturas sanduíche, utilizando camadas finas de um material rígido intercaladas por um núcleo espesso e de pouca resistência. A Figura 19 mostra um exemplo de compósito laminado. 


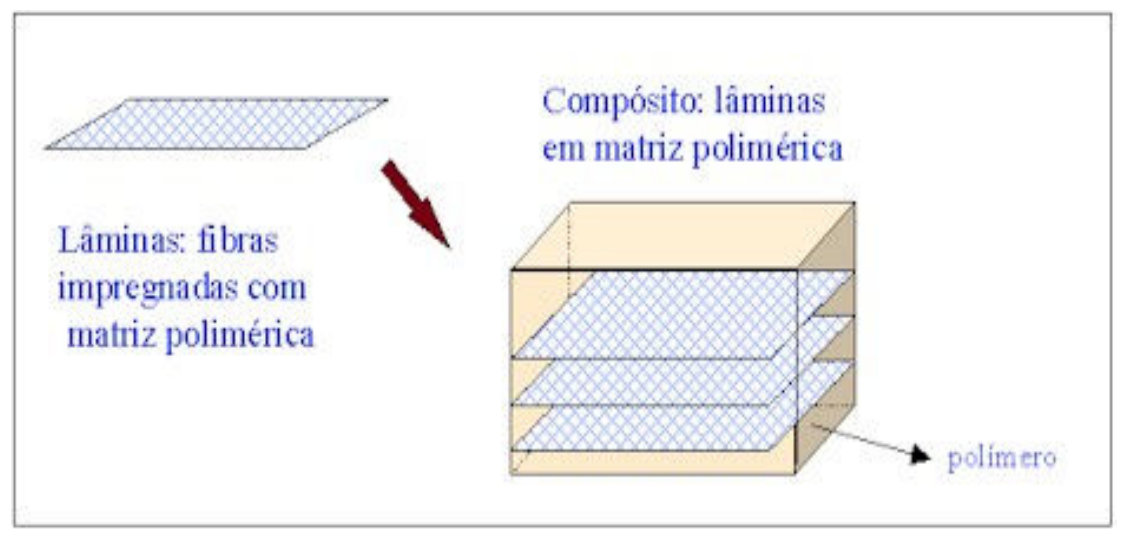

Figura 19: Compósito laminado Fonte: LEPC - UFMG, 2007

Os compósitos podem apresentar-se também na forma de lâminas e, nesse caso, o mesmo é caracterizado por uma única camada (tecido) impregnada pela matriz. São também denominadas de unidades básicas de um material compósito, sendo primordial a determinação de suas propriedades mecânicas de resistência e rigidez na determinação da resposta mecânica para o caso dos laminados.

\subsubsection{Compósitos Poliméricos}

São materiais de moldagem estrutural constituídos por uma fase contínua polimérica (plástico) reforçada por uma fase descontínua fibrosa e que se agregam físico-quimicamente após um processo de polimerização (curado), ou seja, são também denominados de plásticos reforçados com fibras.

Geralmente, a fase descontínua é formada por fibra de vidro, aramida ou de carbono, dependendo da aplicação final. A fase polimérica é normalmente constituída por uma resina termofixa do tipo poliéster insaturada (ortoftálica, tereftálica, isoftálica ou bisfenólica), dissolvida em solvente reativo como o estireno ou ainda uma resina éster vinílica ou epóxi.

$\mathrm{Na}$ moldagem destas duas fases ocorre um "endurecimento" polimérico através de um processo de cura, que acopla as duas fases, proporcionando ao material final, propriedades especiais que definem sua moderna e ampla aplicabilidade. Propriedades como leveza, flexibilidade, durabilidade, resistência, 
adaptabilidade transformam os compósitos poliméricos nos materiais do futuro (LEÃO, 2008).

Várias resinas termoplásticas e termofixas vêm sendo utilizadas como matrizes em compósitos. As resinas termofixas mais utilizadas em compósitos de alto desempenho são as fenólicas, epóxis, bismaleimidas e poliamidas. Essas resinas exibem excelente resistência a solventes assim como a altas temperaturas. Estima-se que mais de três quartos de todas as matrizes de compósitos poliméricos sejam constituídas por polímeros termofixos (MATTHEWS et al., 1994 apud PAIVA et al., 1999).

Nos últimos anos, a procura por materiais ecologicamente corretos tem desenvolvido materiais de matrizes poliméricas com fibras naturais. Os baixos custos destas fibras, originárias de fontes renováveis e inesgotáveis, a baixa densidade, menor abrasão nas máquinas de processamento e a boa adesão à matriz fazem com que o uso destas fibras em compósitos estruturais cresça no setor industrial.

\subsubsection{Características dos Compósitos Poliméricos}

Leveza - Devido ao peso específico das resinas e das fibras de reforço, os produtos fabricados a partir dos compósitos poliméricos apresentam um baixo peso específico, o que faz com que sejam amplamente utilizados nas indústrias aeronáutica, naval e automobilística.

Resistência Química - Apresentam excepcional inércia química, permitindo sua utilização em ambientes agressivos quimicamente. Além disso, inúmeros aditivos especiais e resinas específicas estão à disposição no mercado para solucionar aplicações que requeiram propriedades além das usuais.

Durabilidade - Apresentam alta durabilidade em consequência de sua composição e ao crosslinking polimérico formado durante o processo de moldagem.

Resistência Mecânica - Apresentam excelente resistência mecânica devido às suas características e a variedade de combinações que podem ser realizadas entre as resinas e os materiais de reforço. 
Resistência às Intempéries - Apresentam grande resistência aos efeitos do vento, da umidade, do sol e das oscilações térmicas. Além disso, quando características não usuais são requeridas, aditivos como protetores de UV, agentes anti-dust, resinas especiais são amplamente utilizáveis.

Facilidade na Manutenção - Apresentam fáceis e simples técnicas de reparo e manutenção.

Flexibilidade Arquitetônica - Os compósitos têm uma grande vantagem sobre outros materiais estruturais, pois moldes com formas complexas são facilmente adaptáveis aos processos em utilização.

\subsubsection{Compósitos Poliméricos Reforçados por Fibras Naturais}

Os compósitos reforçados com fibras naturais podem ser uma alternativa, técnica e economicamente viável, em relação àqueles que usam fibras sintéticas, como a fibra de vidro. A incorporação de materiais ligninocelulósicos como componente reforçante em compósitos poliméricos tem recebido atenção crescente devido aos seus preços e volume de aplicações. Esses materiais apresentam diversas vantagens sobre materiais inorgânicos, podendo citar baixa densidade e grande deformabilidade (PACHECO, SANTOS e DIAS, 2003).

O uso de fibras vegetais como reforço em compósitos poliméricos com o objetivo de substituir total ou parcialmente as fibras sintéticas tem recebido muita atenção nos últimos anos (AQUINO et al., 1997). A utilização de fibras sintéticas para o reforço de plásticos e borrachas (polímeros) é uma técnica extensivamente empregada na indústria para a obtenção de materiais com melhor desempenho mecânico. A substituição de fibras sintéticas por fibras vegetais é uma possibilidade bastante importante, pelo fato de esta fibra ser de uma fonte renovável, biodegradável e de baixo custo e por provocar menor impacto ambiental (MATTOSO et al., 1996, apud LEÃO, 2008).

As principais desvantagens no emprego dessas fibras em compósitos poliméricos são relacionadas à natureza polar e hidrofílica, bem como à susceptibilidade destas fibras a ataques de fungos e bactérias. A natureza hidrofílica das fibras vegetais resulta em pobre umectação e adsorção de grande parte dos 
polímeros em sua superfície, resultando em fraca adesão interfacial polímero-fibra (MARROQUIM, 1994, apud LEÃO, 2008).

As fibras vegetais ou lignocelulósicas possuem menor densidade e provocam menor desgaste do que as sintéticas nos equipamentos convencionais de processamento de polímeros (LIGNOCELLULOSICS-PLASTICS COMPOSITES, 1996, apud LEÃO, 2008). Além disso, o Brasil é, sem dúvida, um dos países que possuem a maior biomassa do mundo e a maior extensão territorial cultivável, potenciais estes que devem ser mais bem explorados.

\subsubsection{Influência da interface nas propriedades dos compósitos}

A adesão na interface fibra/matriz exerce profunda influência sobre as propriedades do material compósito. Se a interação ocorre via ligação química (e não somente via ligações hidrogênio, por exemplo), as interações são as mais intensas que se pode esperar (MORI et al., 2007, apud LEÃO, 2008).

As propriedades mecânicas de polipropileno (PP) reforçado com fibras são fortemente influenciadas pelo tipo e grau de interações interfaciais alcançadas, dependendo da eficiência do agente de acoplagem e do compatibilizante interfacial polimérico usado no compósito.

O modelo clássico da micromecânica de reforço em compósitos poliméricos estipula que a interface polímero/reforço seja composta de uma camada restrita fina e rígida, de perfeita adesão interfacial ou com altas forças friccionais entre fibra e matriz, para assegurar uma eficiente transferência de tensão (PLUEDDEMANN, 1991, apud LEÃO, 2008).

As características interfaciais dos materiais compósitos dependem dos aspectos estruturais das vizinhanças e das propriedades físicas e químicas dos constituintes dos compósitos (RANA et al., 1998; GU et al., 2000).

O desenvolvimento de uma ligação química ou de uma interação de natureza física pode fornecer a adesão desejada entre a fibra e a matriz. Quando essa interação não ocorre com a intensidade necessária, pode-se recorrer ao uso de modificadores (GAUTHIER et al., 1998; RANA et al., 1998). 
Quando a ligação matriz-fibra é fraca pode ocorrer uma diminuição da resistência à oxidação, por se estar facilitando a exposição da fibra, e ainda por se estimular a oxidação no interior do compósito. Nem sempre uma melhoria na adesão promove aumento na resistência do compósito, principalmente com relação ao impacto (PAIVA et al., 1999).

\subsubsection{Mecanismo de dano}

Durante sua utilização um material compósito, pode ser submetido a vários tipos de tensões, que dão origem a um mecanismo complexo com diversos tipos de fratura, definidos como "dano", devido ao prejuízo ocorrido nas propriedades mecânicas dos mesmos durante o carregamento (REIFSNIDER e TALUG, 1980). O tipo e a forma de dano podem ser influenciados por diversos fatores, como o tipo e o sentido da carga aplicada, as propriedades físicas, químicas e mecânicas da fibra e da matriz, o processo de fabricação, a configuração do material compósito, os percentuais de fibra, matriz e vazios, a umidade absorvida e a temperatura de trabalho (MARGARIA e AQUINO, 1997; YANG et al., 2000; FELIPE, 1997).

Devido à grande variedade de fatores, é extremamente difícil prever onde e como um dano poderá se formar e, até mesmo, a sua propagação em um material compósito. A literatura mostra que, mesmo quando variando apenas um dos fatores acima mencionados, haverá alterações significativas na formação e propagação do dano (HAMELIN, 1988; HULL, 1988). Segundo a literatura (HAMELIN, 1988; NAIK e KUMAR, 1999; HULL, 1988; MARGARIA e AQUINO, 1997; FELIPE, 1997; YANG et al., 2000), os principais tipos de danos encontrados nos materiais compósitos laminados são:

Fissuração na matriz - ocorrência de uma ou mais fissuras na matriz do material compósito (fratura coesiva na matriz), conforme observado na Figura 20. 


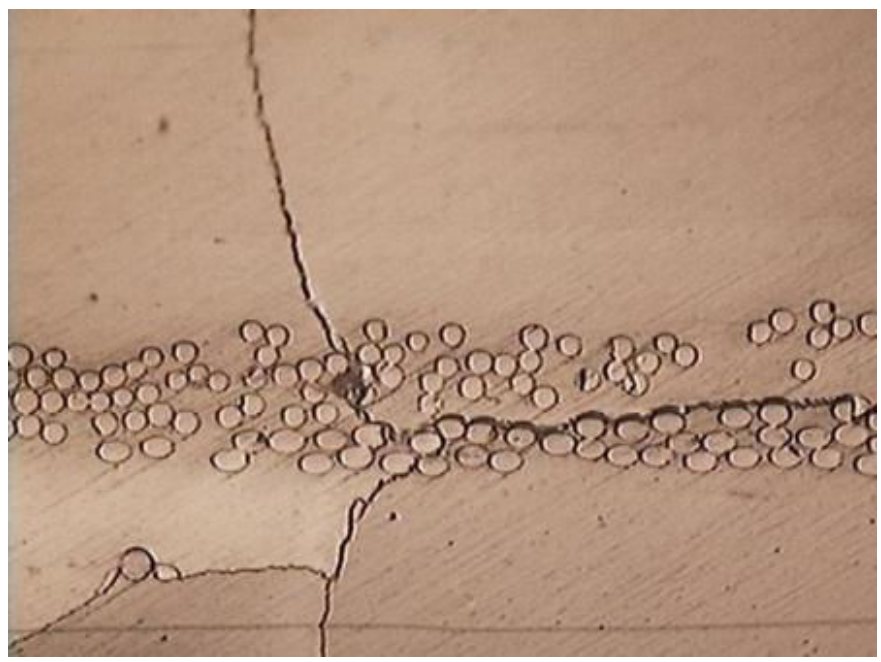

Figura 20: Fissuração em matriz polimérica.

Fonte: base de pesquisa em compósitos, 2005.

- Ruptura da fibra - ocorrência da ruptura transversal ou longitudinal da fibra (fratura coesiva na fibra) (Figura 21).

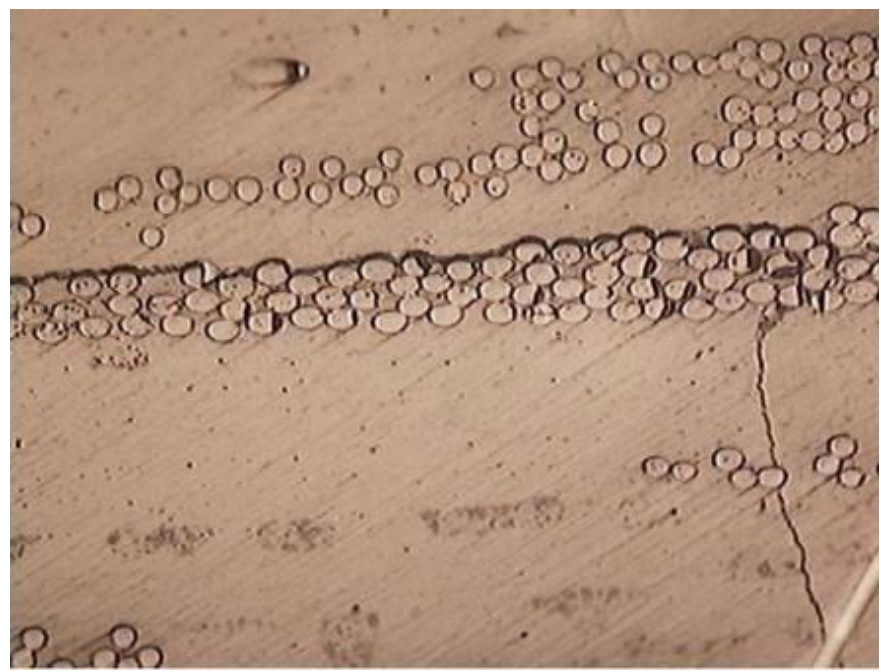

Figura 21: Superfície de fratura de corpos de prova ensaiados em flexão - Ruptura das fibras de juta.

Fonte: base de pesquisa em compósitos, 2005.

- Desaderência fibra matriz - descolamento na interface entre fibra e matriz (fratura adesiva) (Figura 22). 


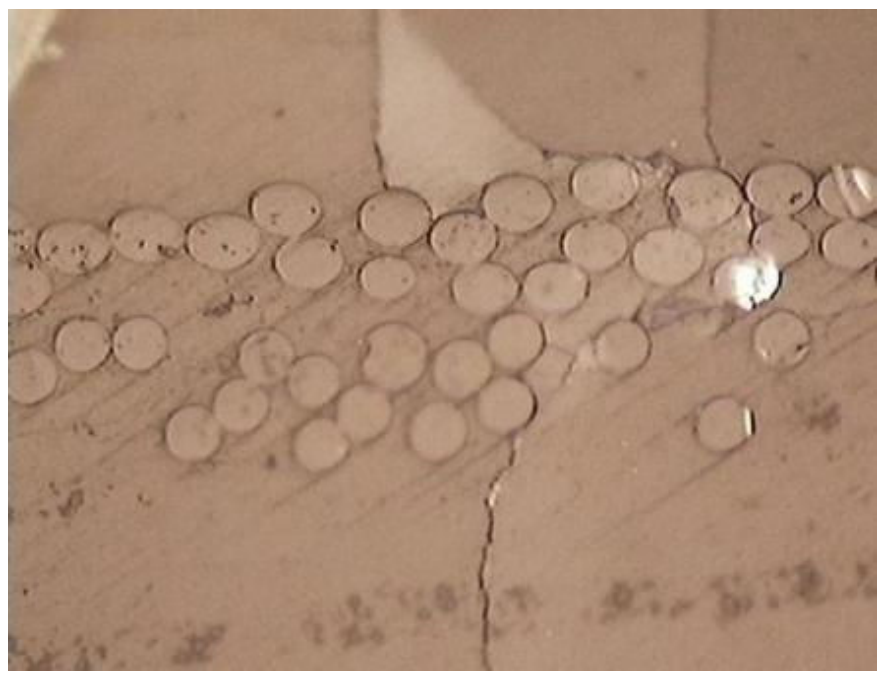

Figura 22: Desaderência fibras de vidro/matriz.

Fonte: Base de pesquisa em compósitos, 2006.

- Delaminação - Desaderência entre as camadas de um compósito laminado (Figura 23).

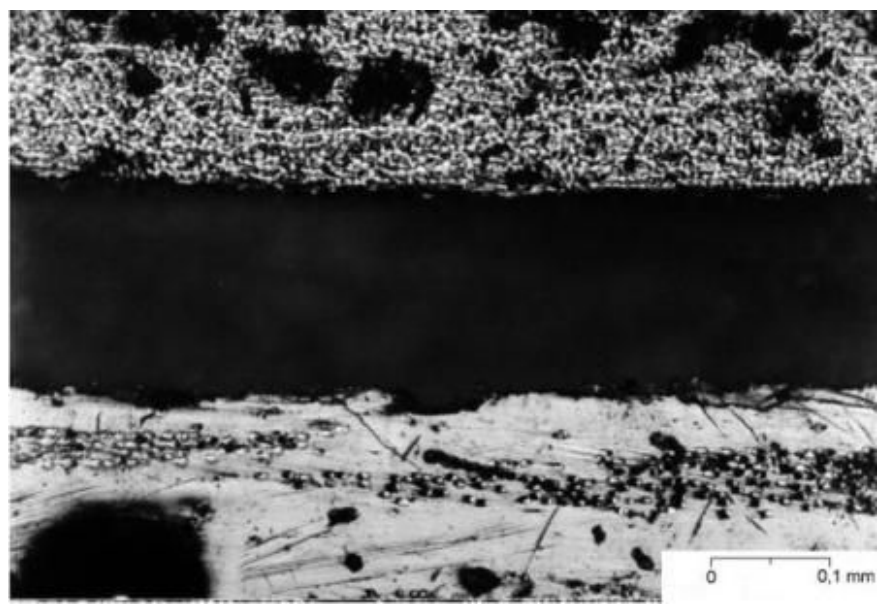

Figura 23: Delaminação entre as camadas de fibras. Fonte: Base de pesquisa em compósitos, 2006.

- Microflambagem - deformação ocasionada nas fibras do laminado quando submetido a esforços de compressão formando pequenas desaderência na interface fibra/matriz (Figura 23). 


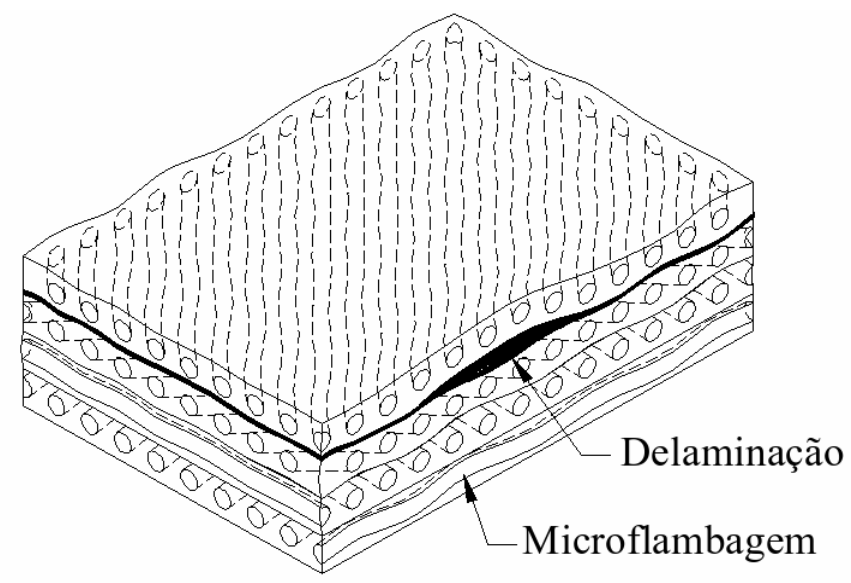

Figura 24: Microflambagem em fibras

Fonte: OLIVEIRA, 2007.

A fissuração na matriz, a ruptura de fibra e a desaderência fibra matriz são tipos de danos que podem ocorrer em qualquer material compósito fibroso, porém a delaminação ocorre em compósitos laminados. Com exceção da microflambagem (que só ocorre com a aplicação de cargas compressivas), os demais tipos de danos aqui descritos são encontrados em diversos tipos de carga aplicada (HAMELIN, 1988; YANG et al., 2000).

É importante salientar que o aumento do dano no material compósito prejudica as propriedades mecânicas do laminado de modo que ocorre um decréscimo das suas constantes elásticas (HAMELIN, 1988; MARGARIA e AQUINO, 1997; FELIPE, 1997; YANG et al., 2000).

\subsubsection{Métodos e processos de fabricação de um laminado}

\subsubsection{Laminação Manual (Hand Lay Up)}

Nesse método, a superfície é devidamente preparada, sendo então utilizado um molde com cera desmoldante e álcool desmoldante, no qual feltros de fibras enrolados, mechas trançadas, mantas ou outros tecidos de fibras são colocados. Impregna-se o molde com resina devidamente preparada, utilizando-se um pincel, e 
para melhorar o processo de impregnação, são usados rolos de alumínio com o objetivo de eliminar bolhas. O processo continua com a colocação das camadas até a obtenção da espessura (ou configuração) desejada para a peça. O moldado é curado sem calor nem pressão (Figura 25).

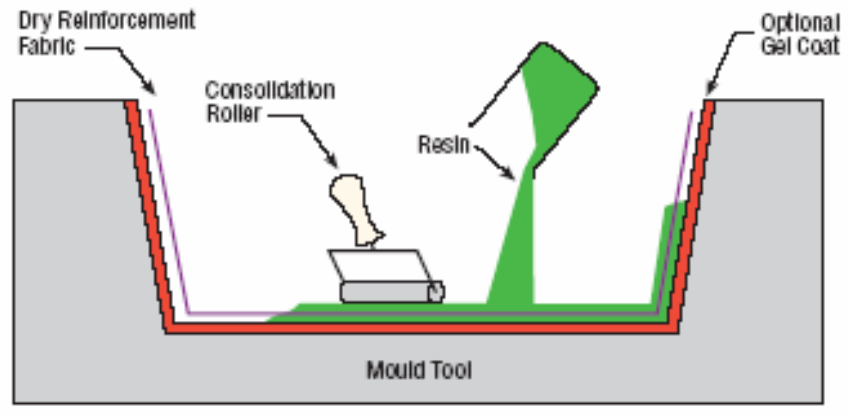

Figura 25: Hand Lay Up

Fonte: Saint Gobain Vertrotex, 2008

\subsubsection{Laminação a pistola}

Neste método, também chamado Spray Up, os fios cortados e a resina são projetados simultaneamente em um molde preparado e um rolo é passado para melhorar o processo de impregnação (diminuindo a presença de bolhas), antes que a resina endureça (Figura 26).

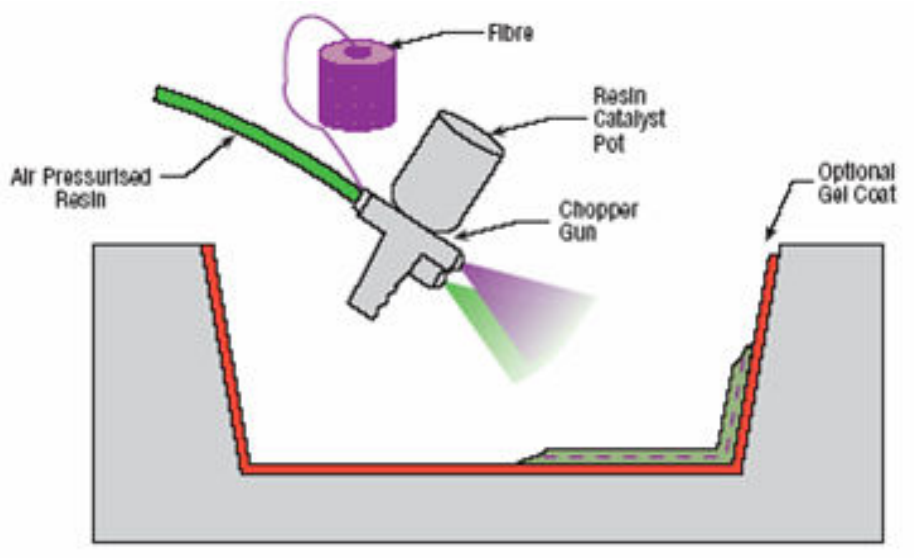

Figura 26: Laminação a Pistola

Fonte: Saint Gobain Vertrotex, 2008 


\subsubsection{Centrifugação}

Aqui, as misturas de fibras e resina são introduzidas em um molde rotatório e curadas "in situ" (Figura 27).

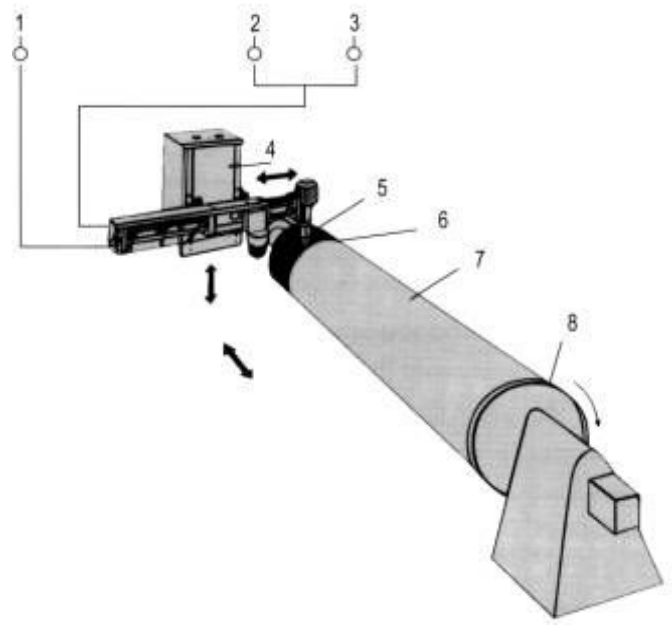

Figura 27: Centrifugação

Fonte: Saint Gobain Vertrotex, 2008.

Legenda:
(1) Prepolímero;
(2) Agente de cura para revestimento macio;
(3) Agente de cura para revestimento duro;
(4) suporte da cabeça misturadora;
(5) cabeça misturadora;
(6) cobertura elastomérica;
(7) cilindro;
(8) acionador do cilindro.

\subsubsection{Enrolamento}

Ou Filament Winding. Neste, a modelagem é feita através de enrolamento das fibras contínuas (roving) sobre molde rotatório. Também podem ser utilizados mantas ou tecidos intercalados às etapas de enrolamento do roving. Este processo é bastante utilizado na fabricação de peças cilíndricas e tubulações (Figura 28). 


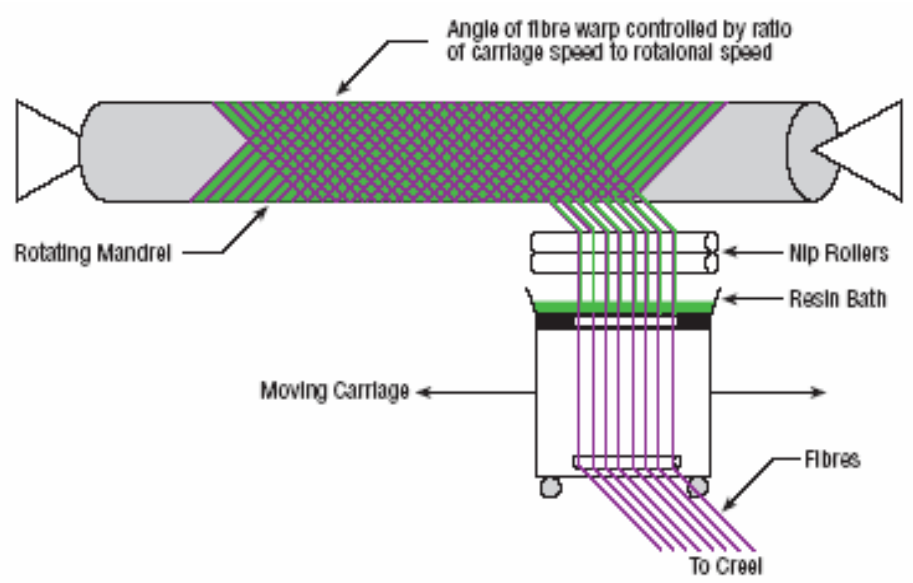

Figura 28: Enrolamento

Fonte: Saint Gobain Vertrotex, 2008.

Os processos em molde fechado são caracterizados pela presença de molde e contramolde, bem como pelo uso de alta tecnologia e produção em média e alta escala. São eles:

Moldagem por compressão: Processo utilizando o pré-impregnado (pregpreg - SMC, BMC, HMC, etc.), ou seja, semiprodutos acabados, nos quais as fibras já se encontram previamente impregnadas pela resina ao serem colocadas no molde aquecido (Figura 29).

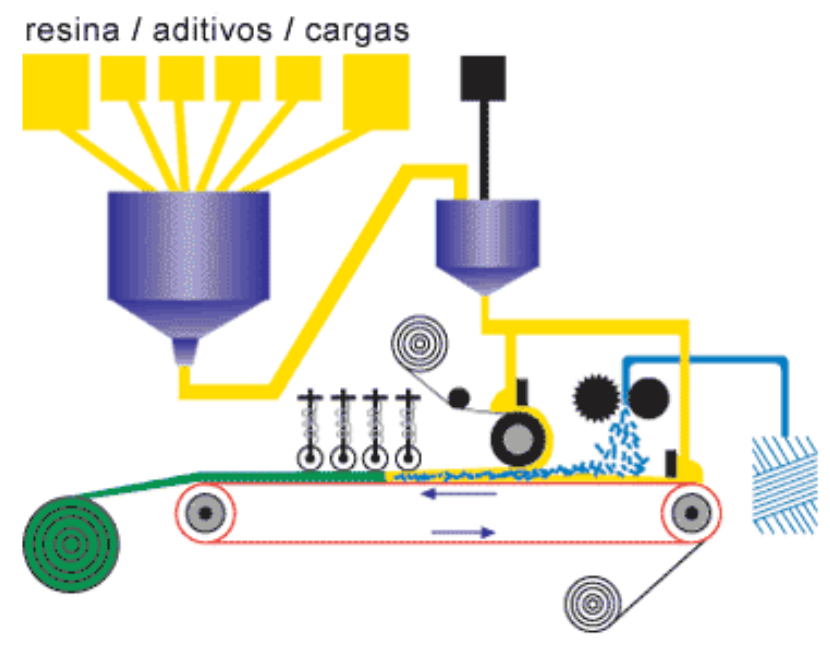

Figura 29: Moldagem por Compressão

Fonte: Saint Gobain Vertrotex, 2008 
Injeção: Processo utilizado para alta produção e na confecção de peças de formas variadas. A injeção da resina é feita por pressão em um molde fechado contendo em seu interior um reforço pré-formado. Os processos mais conhecidos são: RTM (Resin Transfer Molding), RIM (Resin Injection Molding) e R-RIM (Reinforced RIM) (Figura 30).

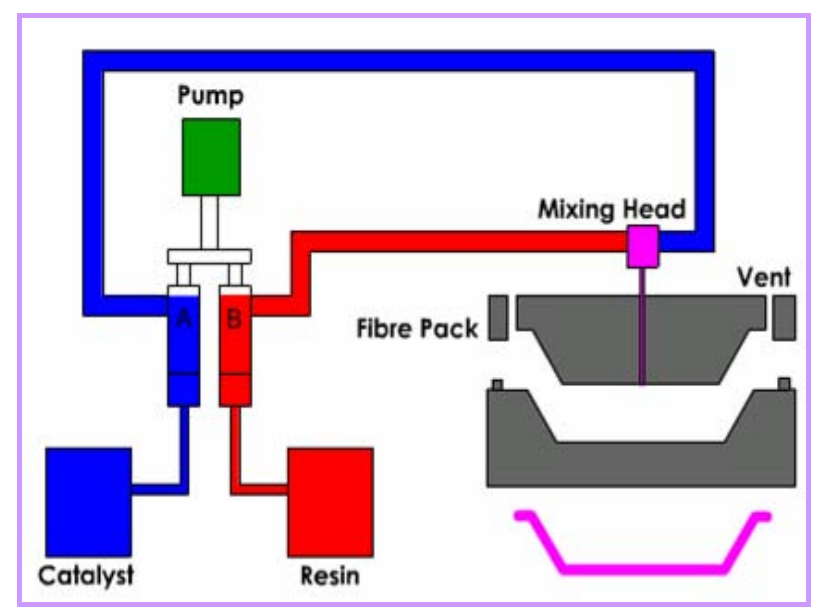

Figura 30: Moldagem por Injeção

Fonte: Saint Gobain Vertrotex, 2008.

Pultrusão: Neste processo, fibras impregnadas com resinas são tracionadas através de moldes aquecidos, produzindo assim a polimerização da resina. É o processo utilizado na obtenção de perfis (Figura 31).

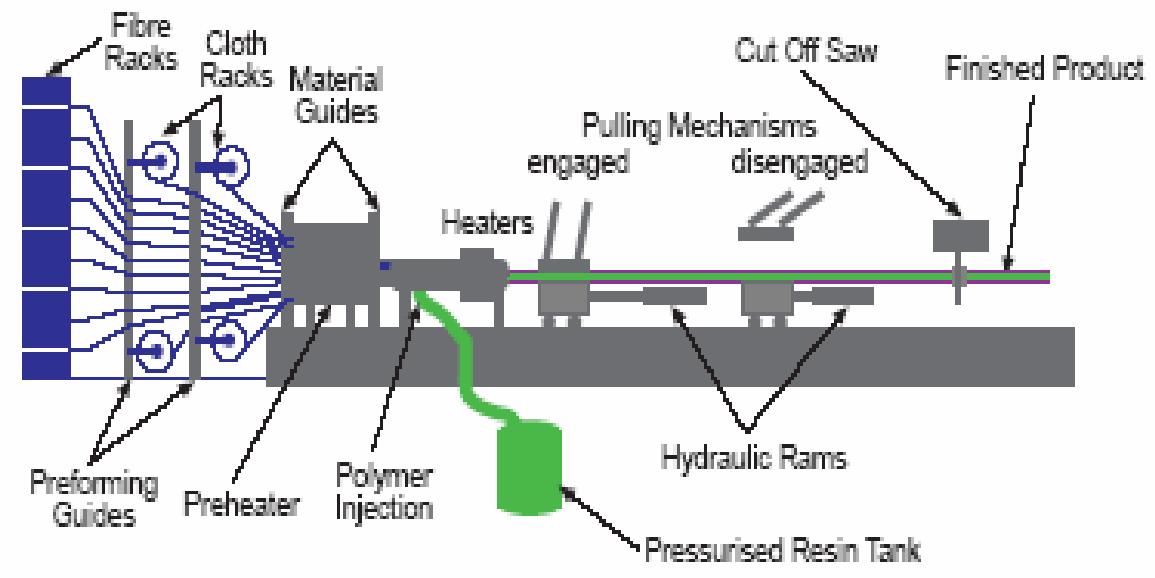

Figura 31: Moldagem por Pultrusão

Fonte: Saint Gobain Vertrotex, 2008 


\section{MATERIAIS E MÉTODOS}

\subsection{METODOLOGIA APLICADA}

Todo o desenvolvimento do projeto foi realizado nos laboratórios do IFBAUnidade de Ensino de Simões Filho, na unidade de Salvador e nos laboratórios da UFRN - Universidade Federal do Rio Grande do Norte, e em laboratórios de empresas da região.

As lâminas foram retiradas do pseudocaule da planta "in natura", de forma manual, a aproximadamente quinze centímetro do solo e com um comprimento de um metro; após isso, o pseudocaule foi seccionado em pedaços de $300 \mathrm{~mm}$, sendo que o mesmo possui em média $30 \mathrm{~cm}$ de diâmetro, e uma bananeira possui em média de três a cinco metros de altura. As placas foram retiradas com auxílio de um estilete e desfiadas utilizando-se uma escova de aço em um processo manual; depois, foram colocadas para secar ao ar livre por um período de aproximadamente 3 a 4 dias e, após secas, foram cortadas com uma tesoura em um tamanho padrão (30 mm a $120 \mathrm{~mm}$ ). Utilizou-se uma resina pré-acelerada do tipo AZ-46 padrão, produzida pela empresa AraAshland, e foram utilizados um molde de granito e cera desmoldante de carnaúba, tendo o processo sido realizado através de laminação manual (Hand Lay Up).

Foram confeccionadas três placas do compósito com as porcentagens de fibras especificadas e dez corpos de prova (cinco grandes e cinco pequenos) na seguinte configuração: $1^{a}$ placa com $3 \%$ em volume de fibras, $2^{a}$ placa com $6 \%$ e por último a $3^{a}$ placa com $9 \%$. O diâmetro médio da fibra de bananeira foi obtido de forma aleatória com 15 (quinze) fibras e nelas foram feitas três medidas com um micrômetro de resolução 0,01 mm, marca Mitutoyo em uma sala climatizada a aproximadamente $22^{\circ} \mathrm{C}$. A decisão de serem tomadas três medidas foi em virtude da não-conformidade das fibras, e vale salientar que as mesmas foram tratadas e secas ao ar livre. As medidas número 1 e 3 foram feitas nas extremidades e a de número 2, no meio da fibra, conforme Tabela 4 abaixo. 
Tabela 4: Diâmetro das fibras de bananeira secas e sem tratamento ( $\mathrm{mm}$ )

\begin{tabular}{l|l|l|l|l}
\hline \hline & $\mathbf{1}^{\mathbf{a}}$ medida & $\mathbf{2}^{\mathbf{a}}$ medida & $\mathbf{3}^{\mathbf{a}}$ medida & média \\
\hline $\mathbf{1}$ & 0,11 & 0,12 & 0,11 & 0,11 \\
\hline $\mathbf{2}$ & 0,12 & 0,13 & 0,11 & 0,12 \\
\hline $\mathbf{3}$ & 0,09 & 0,1 & 0,08 & 0,09 \\
\hline $\mathbf{4}$ & 0,11 & 0,11 & 0,1 & 0,1 \\
\hline $\mathbf{5}$ & 0,13 & 0,15 & 0,17 & 0,15 \\
\hline $\mathbf{6}$ & 0,16 & 0,14 & 0,13 & 0,14 \\
\hline $\mathbf{7}$ & 0,04 & 0,05 & 0,05 & 0,04 \\
\hline $\mathbf{8}$ & 0,09 & 0,1 & 0,1 & 0,09 \\
\hline $\mathbf{9}$ & 0,17 & 0,14 & 0,11 & 0,14 \\
\hline $\mathbf{1 0}$ & 0,09 & 0,09 & 0,08 & 0,08 \\
\hline $\mathbf{1 1}$ & 0,13 & 0,12 & 0,11 & 0,12 \\
\hline $\mathbf{1 2}$ & 0,1 & 0,09 & 0,09 & 0,09 \\
\hline $\mathbf{1 3}$ & 0,05 & 0,04 & 0,04 & 0,04 \\
\hline $\mathbf{1 4}$ & 0,09 & 0,07 & 0,08 & 0,08 \\
\hline $\mathbf{1 5}$ & 0,08 & 0,09 & 0,08 & 0,08 \\
\hline \hline
\end{tabular}

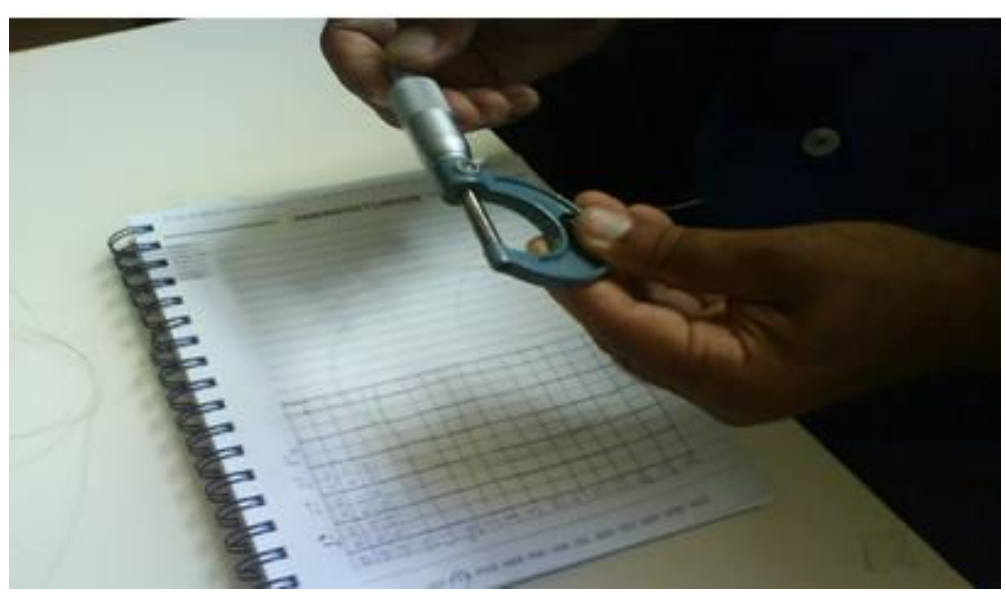

Figura 32: Medição do diâmetro da fibra

Fonte: Foto do Autor, 2009. 


\subsubsection{FÓRMULAS UTILIZADAS}

$$
\begin{gathered}
\sigma=\frac{F}{S} \\
\mathrm{\sigma}=\text { tensão }(\mathrm{MPa}) \\
\mathrm{F}=\text { força }\left(\mathrm{N} / \mathrm{mm}^{2}\right) \\
\mathrm{S}=\text { área transversal }(\mathrm{mm})
\end{gathered}
$$

$$
\begin{gathered}
E=\frac{\mathrm{T}}{\varepsilon} \\
\begin{array}{c}
\mathrm{E}=\text { modulo de elasticidade na tração }(\mathrm{GPa}) \\
\square=\text { deformação }(\mathrm{mm}) \\
\mathrm{T}=\text { tensão }(\mathrm{MPa})
\end{array} \\
\mathrm{E}=\frac{\mathrm{P} \cdot l^{3}}{4 . W^{3} \cdot h^{3 . \cdot} \cdot v} \\
\begin{array}{r}
\mathrm{E}=\text { modulo de elasticidade na flexão }(\mathrm{GPa}) \\
\mathrm{P}=\text { carga }(\mathrm{N})
\end{array} \\
\begin{array}{r}
\mathrm{I}=\text { comprimento útil do corpo de prova }(\mathrm{mm}) \\
\mathrm{w}=\text { largura do corpo de prova }(\mathrm{mm})
\end{array} \\
\mathrm{h}=\text { altura do corpo de prova }(\mathrm{mm}) \\
\mathrm{v}=\text { flecha }(\mathrm{mm})
\end{gathered}
$$




\subsubsection{Teor de Cera}

Conforme os estudos de Leão (2008), as ceras formam uma camada de proteção nas fibras que confere um caráter oleofílico e hidrofóbico nas superfícies. São constituídas de diferentes tipos de alcoóis, os quais são insolúveis em água fria e em diversos ácidos (palmítico, oleaginosos, esteárico), porém podem ser extraídos com solventes orgânicos e água quente.

O processo de limpeza da cera das fibras da bananeira se deu no laboratório de química do IFBA - Campus de Salvador - e consistiu em imergir $160 \mathrm{~g}$ de fibras em uma solução de Hexano por um período de 90 minutos, compreendendo a lavagem e secagem em uma capela com exaustor, e depois lavagem e fervura por um período de 30 minutos para auxiliar a retirada da cera das fibras. As Figuras 33 a 35 mostram o processo de retirada da cera da fibra de bananeira durante esta pesquisa.

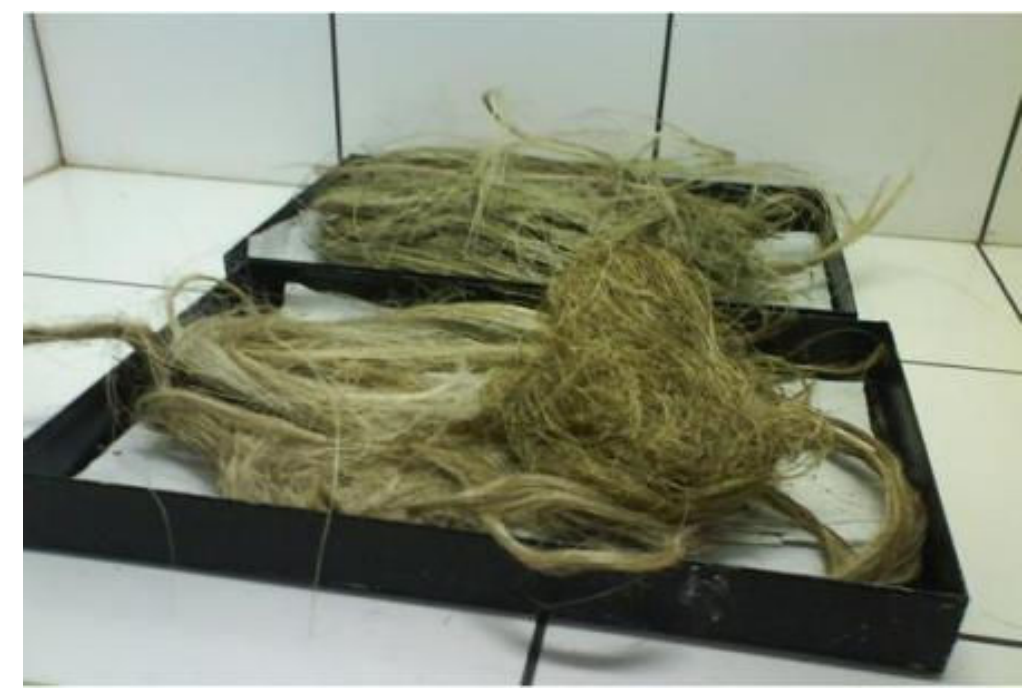

Figura 33: Preparação das fibras para limpeza de cera (1) Fonte: Foto do Autor, 2009. 


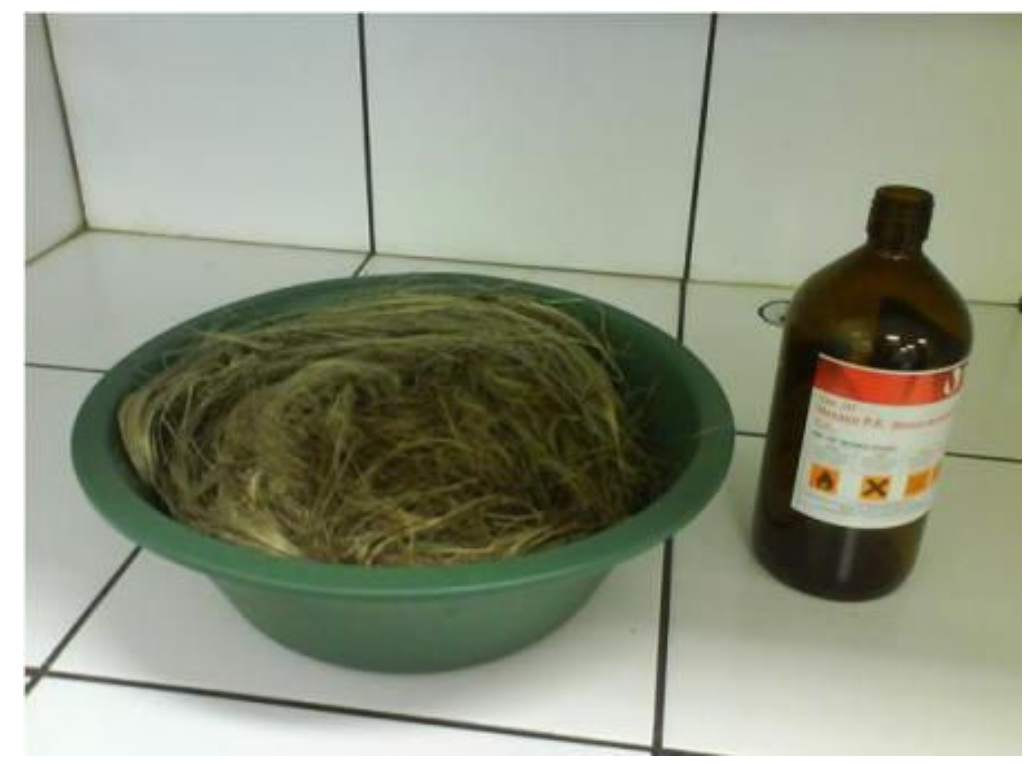

Figura 34: Preparação das fibras para limpeza de cera (2) Fonte: Foto do Autor, 2009.

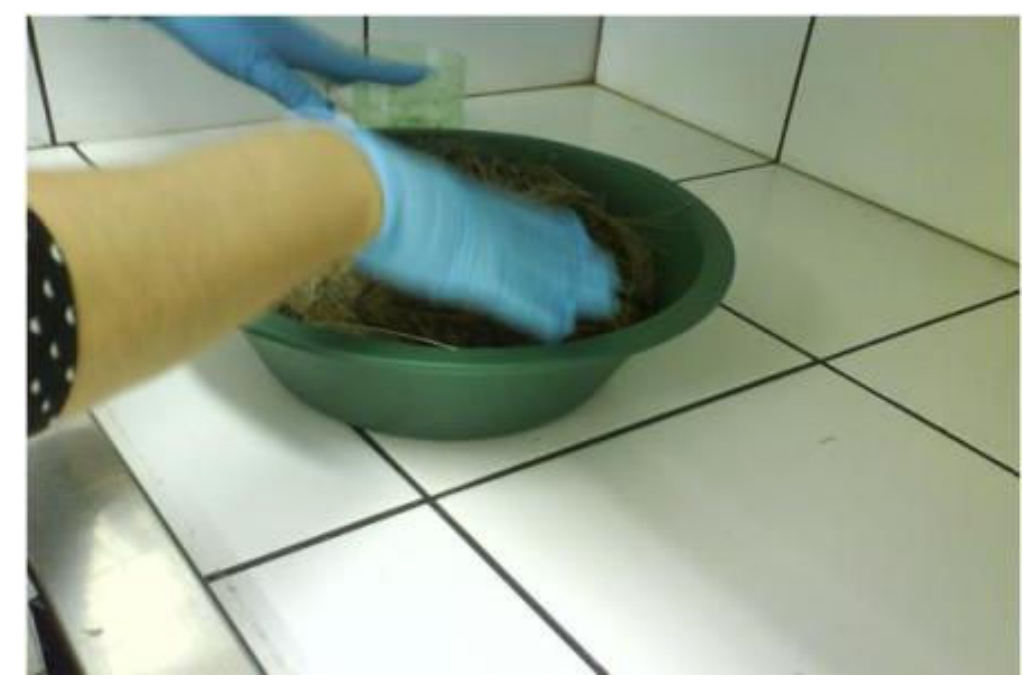

Figura 35: Fibras sendo lavadas Fonte: Foto do Autor, 2009.

\subsubsection{Hexano}

Neste ponto, faz-se necessário esclarecer o que vem a ser o Hexano. Tratase de um hidrocarboneto alcano com a fórmula química $\mathrm{CH} 3(\mathrm{CH} 2) 4 \mathrm{CH} 3$. O prefixo "hex" refere-se aos seus seis átomos de carbono, ao passo que a terminação "ano" 
indica que os seus carbonos estão conectados por ligações simples. Os isômeros de hexano são altamente irreativos, e são frequentemente usados como solvente inerte em reações orgânicas. São também componentes comuns da gasolina.

Dentre os perigos físicos e químicos, tem-se que o hexano é um liquido inflamável e nocivo, com efeitos adversos potenciais à saúde humana, como alteração do comportamento, por exemplo.

Os principais sintomas de contaminação, em casos de exposição prolongada, são dor de cabeça, náuseas, tonteiras, perturbações visuais e auditivas, além de excitação (COMPANHIA AMBIENTAL DO ESTADO DE SÃO PAULO, 2001; OXFORD UNIVERSITY, 2005).

\subsubsection{Preparação das placas para a fabricação dos corpos de prova}

Primeiramente, foram pesadas em uma balança eletrônica, Quimis - 200 (Figura 36), as quantidades de cada placa a ser confeccionada respectivamente para $3 \%, 6 \%, 9 \%$; em seguida, as fibras foram colocadas no molde de mármore, sendo então efetuada uma umidificação com água destilada com spray para melhorar a moldagem e, depois, colocando-se em uma prensa hidráulica com uma placa de madeira para dar uma melhor compressibilidade, formando uma manta. Esta operação durou aproximadamente uma semana para cada placa, entre a moldagem e secagem.

Após a retirada, as placas foram colocadas em um molde de granito com dimensões de $400 \mathrm{~mm} \times 250 \mathrm{~mm} \times 7 \mathrm{~mm}$, devidamente preparado para a impregnação pelo método de fabricação Hand Lay Up com a resina poliéster ortoftálica do tipo Arazen - 4.1 PA (fornecida pela Bahia Química S.A.), que foi catalisada com $10 \%$ do volume total da resina, ou seja, $10 \mathrm{ml}$ para cada $100 \mathrm{ml}$ de resina utilizada, levando um tempo de aproximadamente 40 minutos pra gelificar (atingir o ponto de gel) e mais duas horas para atingir a cura total.

Em seguida, a placa foi colocada em uma estufa artesanal para efetuar a póscura por mais quatro horas. Percebeu-se que a impregnabilidade ou a facilidade de molhação (molhabilidade) da fibra com a resina é difícil e a absorção é grande por 
parte das fibras, sendo necessária uma grande atenção para não haver fibras descobertas, mascarando assim os resultados obtidos.

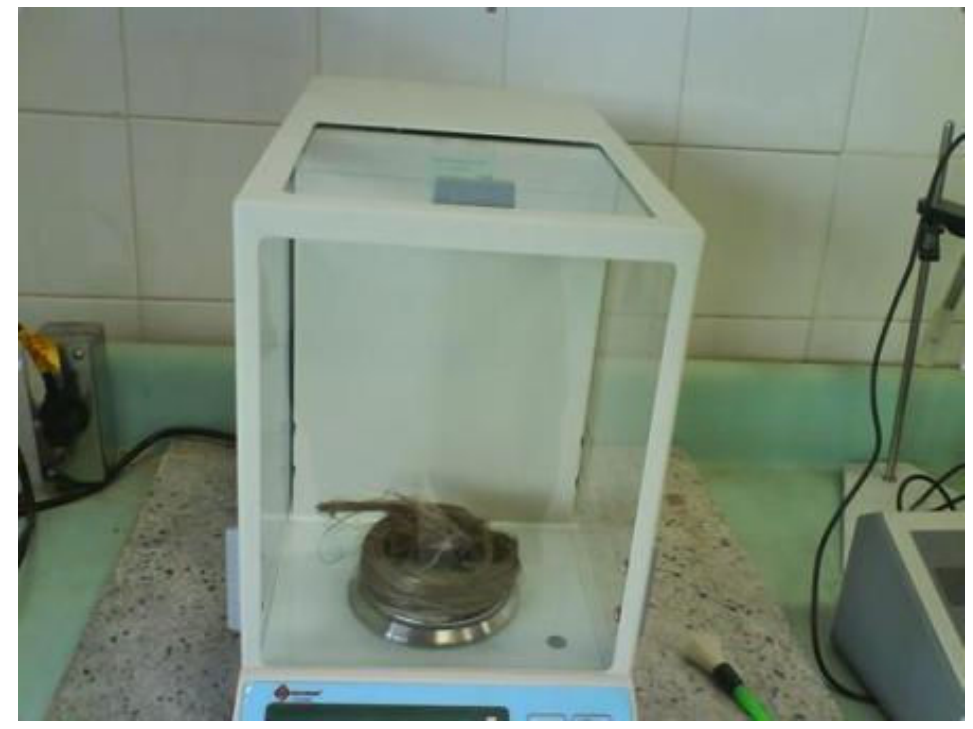

Figura 36: Balança analítica de precisão - Lab. IFBA - Simões Filho Fonte: Foto do Autor, 2009.

Depois de desmoldadas, as placas foram levadas para serem cortadas na Acriplanos, empresa localizadas em Salvador, em uma fresadora do tipo Router T 30 (Figura 37).

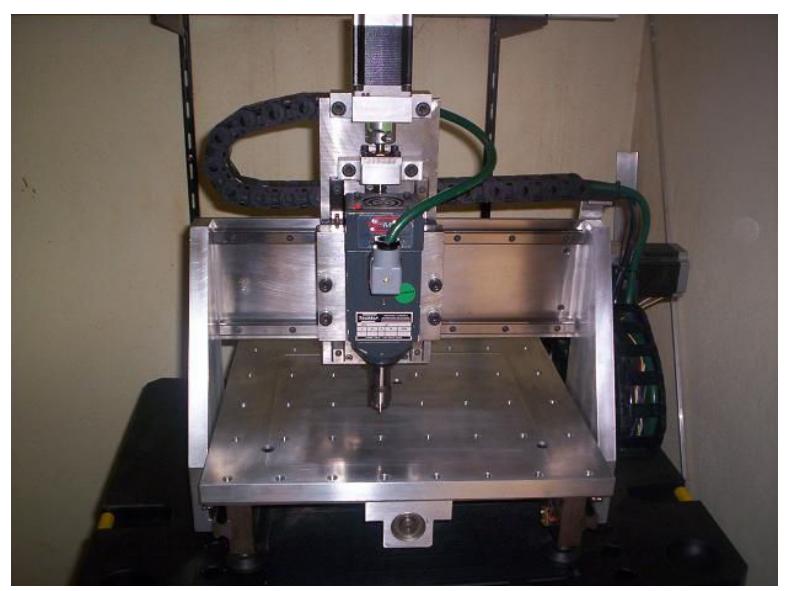

Figura 37: Fresadora tipo Router T- 30

Fonte : http://www.ibiubi.com.br 
Foi utilizada uma freza de $3 \mathrm{~mm}$ para efetuar os cortes de acordo com as especificações da American Society for Testing and Materials (ASTM, 1990), ou seja:

Tração uniaxial - $203 \mathrm{~mm} \times 25 \mathrm{~mm} \times 6 \mathrm{~mm}$

Flexão em três pontos - $125 \mathrm{~mm} \times 10 \mathrm{~mm} \times 6 \mathrm{~mm}$

Todos os corpos de prova ficaram com um sobrematerial de aproximadamente $1 \mathrm{~mm}$ para posterior lixamento e polimento. Para isso, preparouse uma bancada metalográfica, na qual foi feito o lixamento dos corpos de prova de maneira manual com as lixas d'água de números 220,320,400,600, e 1200, por um período de aproximadamente 60 minutos entre lixamento e polimento (tempo esse baseado na analogia com a preparação de cp para metalurgia), a fim de se atingir as dimensões desejadas (Figuras 38 e 39).

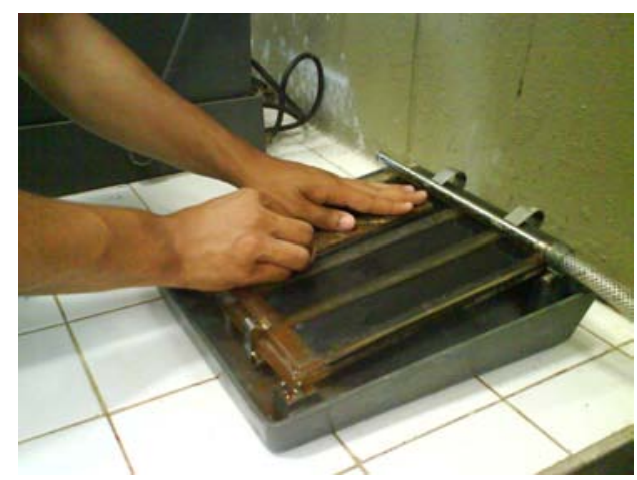

Figura 38: Lixamento

Fonte: Foto do Autor.

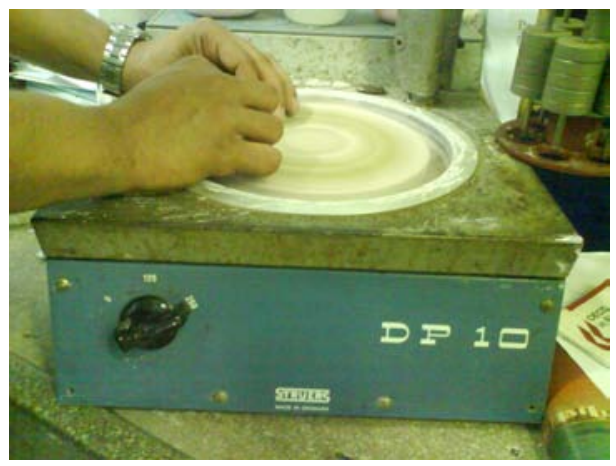

Figura 39: Polimento

Fonte: Foto do Autor. 


\subsubsection{Testes}

Foram realizados testes de tração uniaxial para definir o módulo de elasticidade e módulo de ruptura, absorção de umidade e flexão em três pontos, para definir a tensão de ruptura e a resistência última, e a caracterização térmica, no intuito de melhor especificar a aplicabilidade deste compósito de forma comercial.

\subsubsection{Ensaio de absorção de umidade}

Para o ensaio de absorção de umidade foram confeccionados trinta corpos de prova, sendo cinco grandes e cinco pequenos para cada percentagem de fibra. Foi feita uma microscopia óptica nos CPs, (laboratório da Gerdau) para identificar possíveis defeitos de fabricação como bolhas e vazios etc. (Figuras 40 a 42).

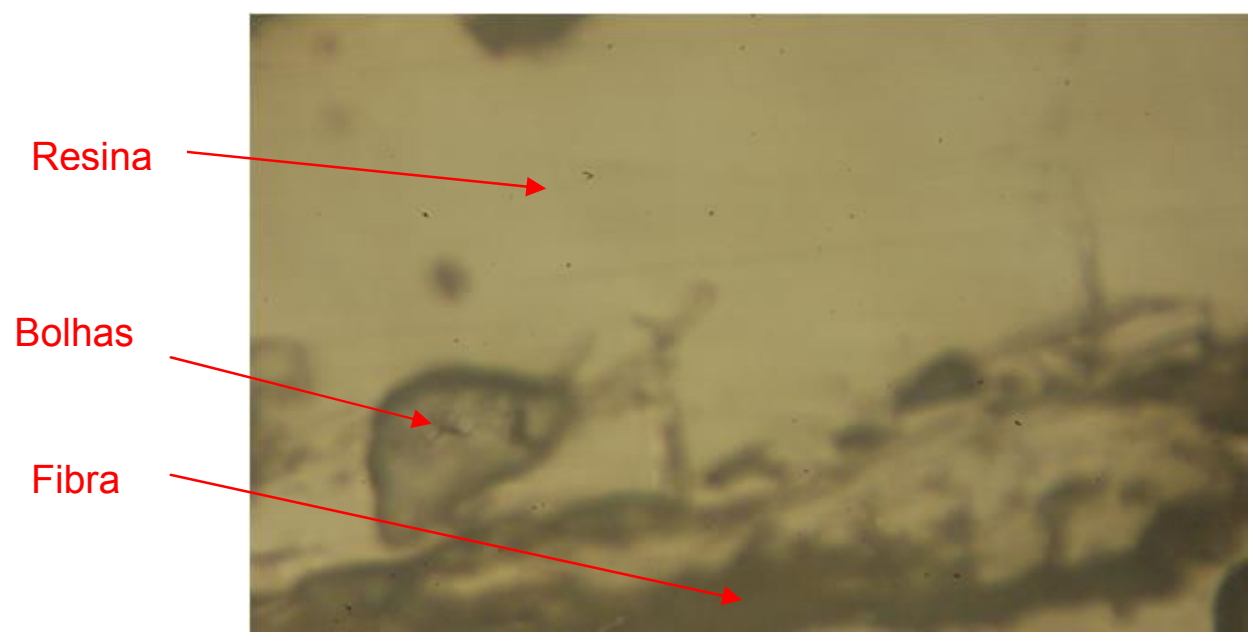

Figura 40: Microscopia Ótica CP3\%

Fonte: Foto do Autor, 2009. 


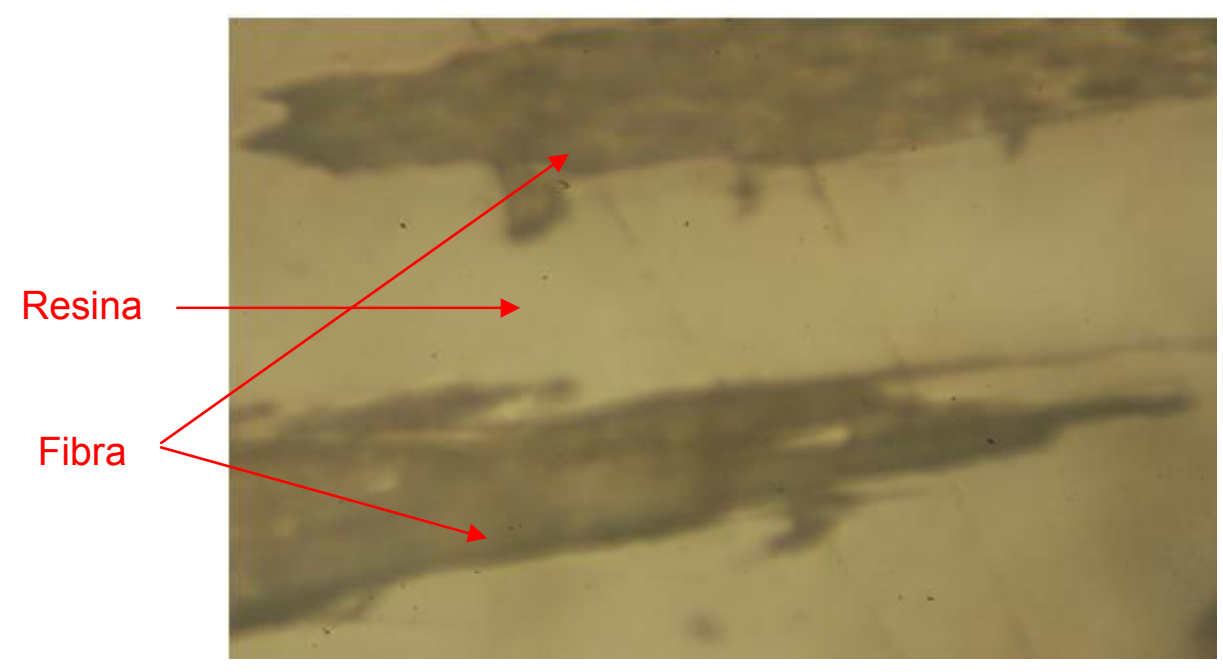

Figura 41: Microscopia Ótica CP6\%

Fonte: Foto do Autor, 2009.

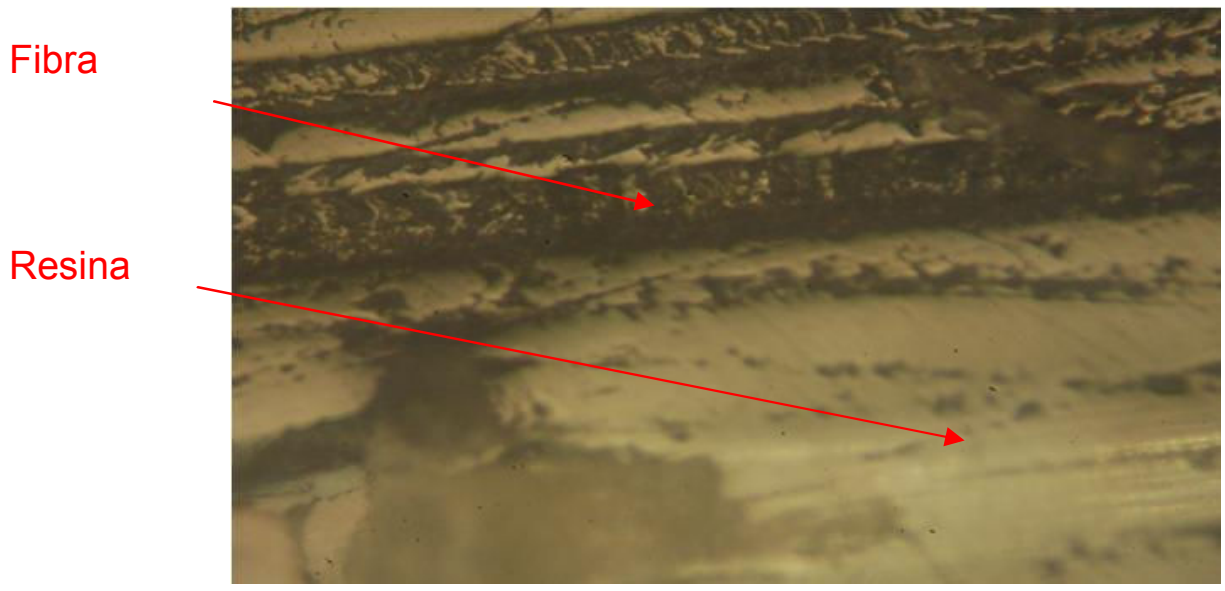

Figura 42: Microscopia Ótica CP9\%

Fonte: Foto do Autor, 2009.

Os corpos de prova foram pesados e colocados em um recipiente plástico contendo água destilada, sendo este devidamente tampado, para a observação da absorção de umidade por parte do compósito em decorrência do tempo de imersão até a sua saturação, de acordo com a norma ASTM D 570-95 (ASTM, 1995). Todo esse processo é lento, levando aproximadamente 120 dias, e o acompanhamento se deu a princípio com a pesagem de duas em duas horas, sendo aumentado este tempo gradativamente. Para realizar as pesagens, cada um dos corpos de prova foi retirado com o auxílio de uma pinça metálica, evitando-se assim o contato com as mãos e, consequentemente, não transferindo massa para os mesmos pela 
oleosidade da pele; após isso, foram secados com papel absorvente e pesados em uma balança de cinco dígitos da marca Quimis - Q 500L210C, com capacidade máxima de $210 \mathrm{~g}$, a qual foi devidamente tarada, sendo os dados lançados em uma tabela para posterior plotagem. Até então, a absorção ainda não tinha sido total, porém, aos oitenta dias de imersão, pôde ser vista uma tendência a saturação. Este ensaio foi totalmente realizado no laboratório de microscopia do IFBA - SF.

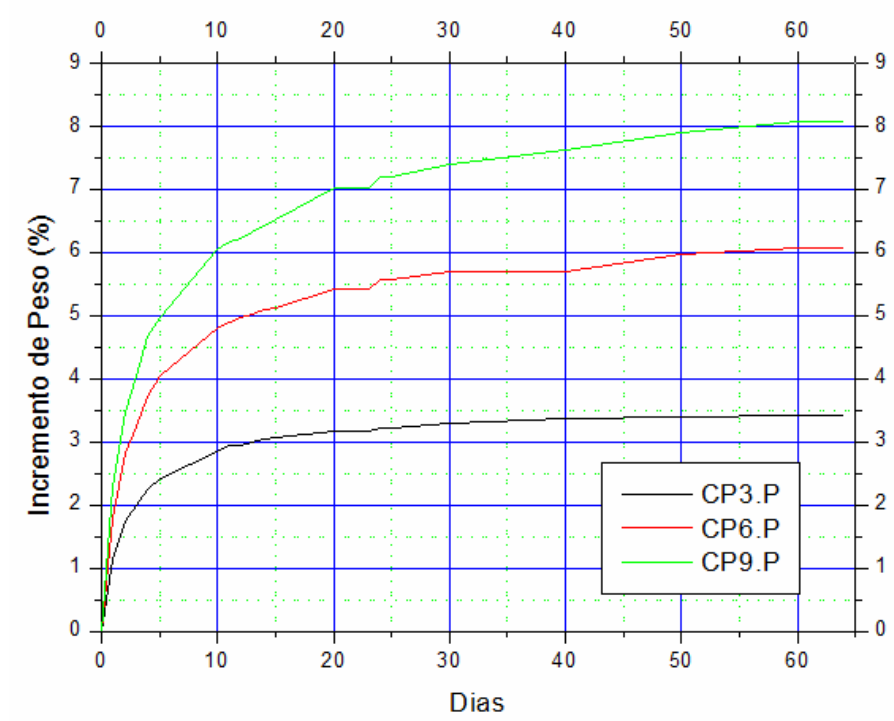

Gráfico 1: Aumento de Peso X Dias (1)

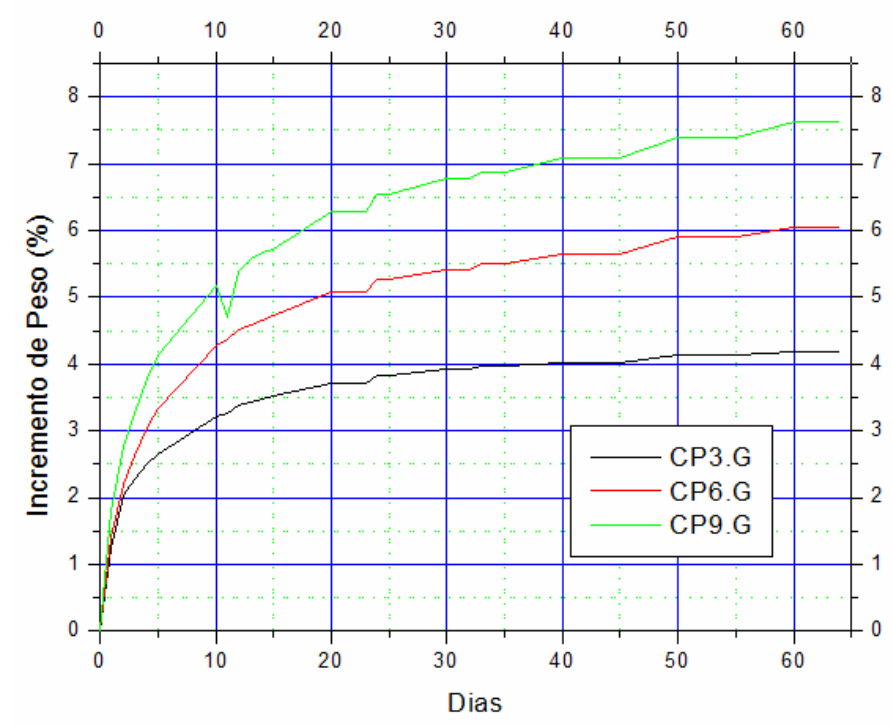

Gráfico 2: Aumento de Peso X Dias (2) 


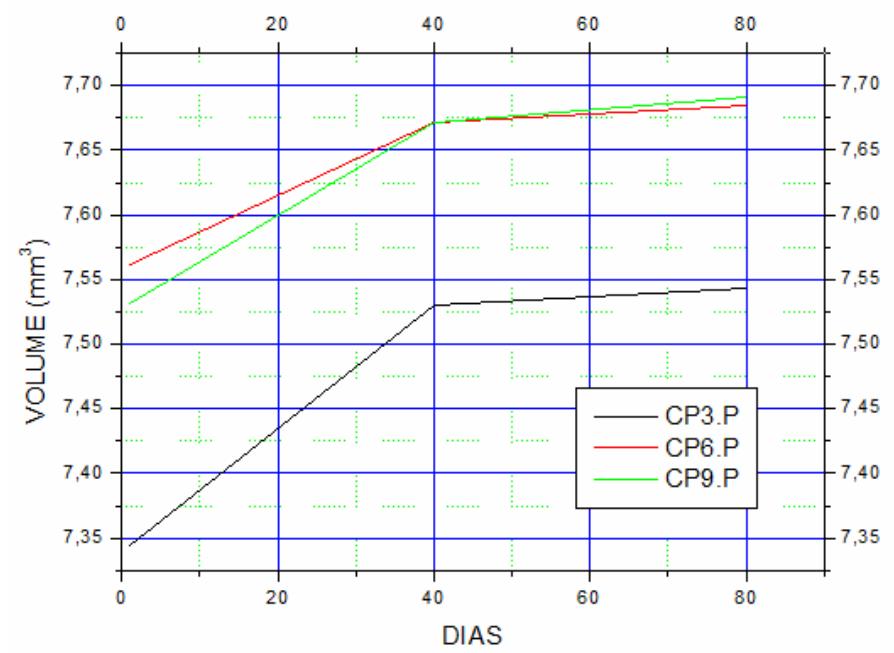

Gráfico 3: Aumento de Volume X Dias (1)

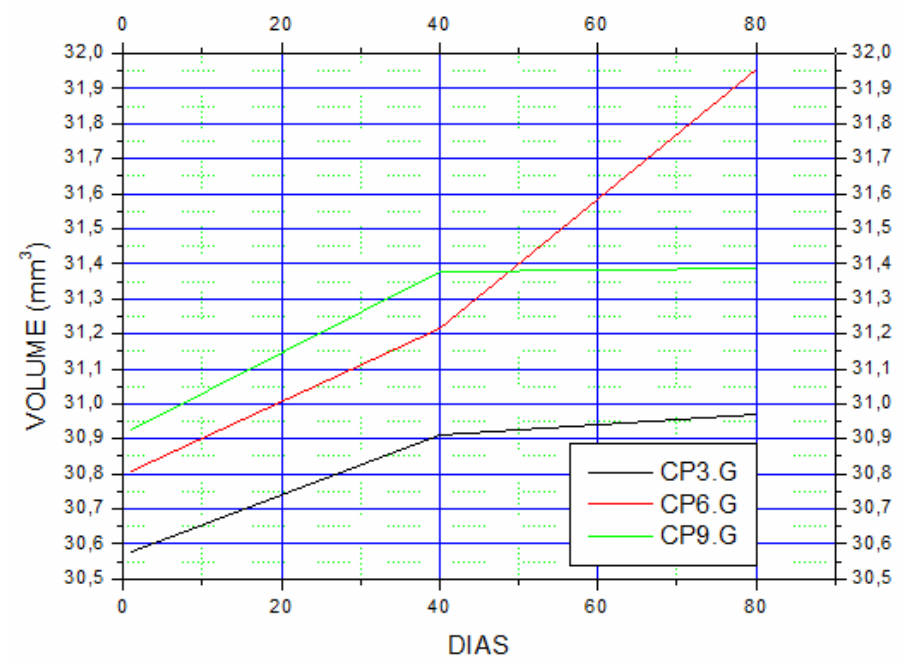

Gráfico 4: Aumento de Volume X Dias (2)

\subsubsection{Ensaio de tração uniaxial}

Os ensaios de tração foram realizados em uma máquina de ensaios mecânicos SHIMADZU, modelo AG-1, com capacidade máxima de $250 \mathrm{KN}$, na qual se utilizou uma placa de aquisição de dados para obtenção dos valores de deslocamento e carga aplicada no material. Cuidados especiais foram tomados antes da realização dos ensaios, como, por exemplo, ajustes prévios dos CPs nas 
"garras" da máquina, de forma a amenizar problemas de "arrastes" no início do carregamento; desta forma, consegue-se um melhor controle sobre os dados relacionados ao deslocamento. Com isso, foi possível se obter o limite de resistência, o módulo de elasticidade longitudinal (na direção de aplicação da carga) e a deformação de ruptura dos compósitos. Por último, efetuou-se o cálculo de um valor médio para cada parâmetro estudado. As dimensões dos corpos de prova seguiram a norma ASTM D3039 (1990). O valor da velocidade de deslocamento dos ensaios foi de $1 \mathrm{~mm} / \mathrm{min}$., e os ensaios foram feitos à temperatura de $22^{\circ} \mathrm{C}$, com uma umidade relativa do ar de $56 \%$.

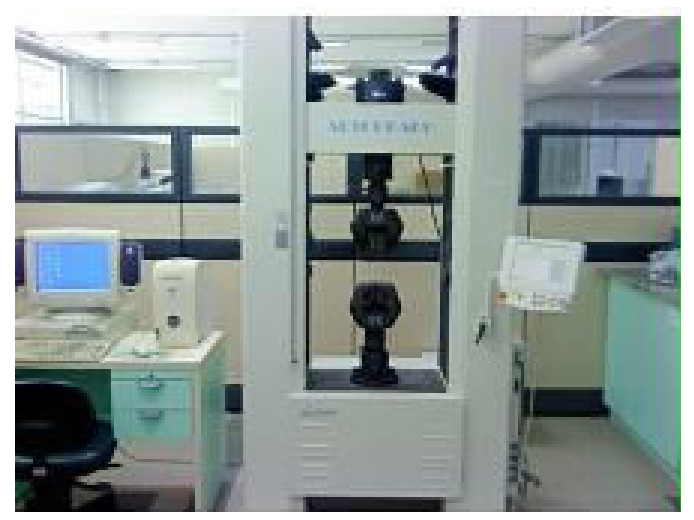

Figura 43: Máquina de Tração SHIMADZU - AG1 Fonte: Foto do Autor, 2009.

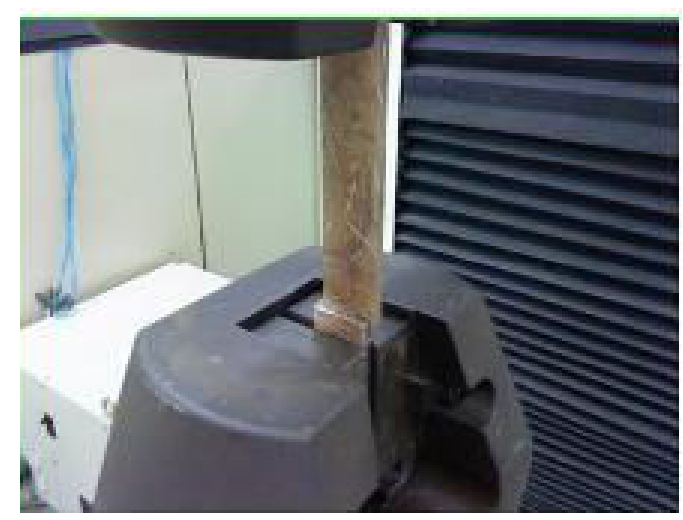

Figura 44: Corpo de Prova Tracionado Fonte: Foto do Autor, 2009. 


\subsubsection{Ensaio de termogravimetria}

Este é um ensaio que permite medir a perda de massa de uma determinada substância ou material em função do aquecimento controlado e do tempo, caracterizando assim o comportamento térmico dos materiais. A metodologia básica da termogravimetria consiste em uma balança eletrônica de precisão acoplada a um forno que tenha o aumento controlado da temperatura de forma linear com o tempo. Nesta pesquisa, a amostra foi analisada em um analisador termogravimétrico, TGA$51 \mathrm{H}$, marca SHIMADZU (Figuras 45 e 46), em uma atmosfera de ar normal, pois reflete o ambiente em que o compósito será utilizado, um cadinho de platina, com um gradiente de temperatura de $28^{\circ} \mathrm{C}$ a $500^{\circ} \mathrm{C}$, a uma taxa de aquecimento de $10^{\circ} \mathrm{C}$ por minuto. A amostra em forma de raspa foi colocada em um cadinho devidamente tarado acoplado a uma plataforma; dentro dele foram colocados $5 \mathrm{mg}$ de cada amostra por vez, para serem determinadas as temperaturas de degradação para cada concentração do compósito. O cadinho foi então envolvido pelo forno elétrico, de maneira tal que a amostra pudesse ter sua temperatura monitorada em função da variação da potência do forno.

Os resultados são apresentados em forma de curvas termogravimétricas (TG), em que a variação do peso é constatada em relação ao aumento controlado da temperatura ou do tempo. Assim sendo, qualquer mudança na massa que venha a ocorrer em temperaturas próximas logo será identificada. Alguns fatores que podem afetar o resultado de um ensaio termogravimétrico são: efeitos instrumentais (velocidade do forno, atmosfera, forma e material do cadinho), características da amostra (peso, granulometria, umidade, forma de preparação), entre outros.

Parâmetros :
a. Detector - TGA - $51 \mathrm{H}$
b. Celula - Platinum
c. Atmosfera - Ar
d. Taxa $-50.00 \mathrm{ml} / \mathrm{min}$.
e. Taxa temperatura $-10^{\circ} \mathrm{C} / \mathrm{min}$.
f. Faixa de ensaio $-0^{\circ}$ ate $500^{\circ} \mathrm{C}$
g. Peso $-5,0 \mathrm{mg}$ 


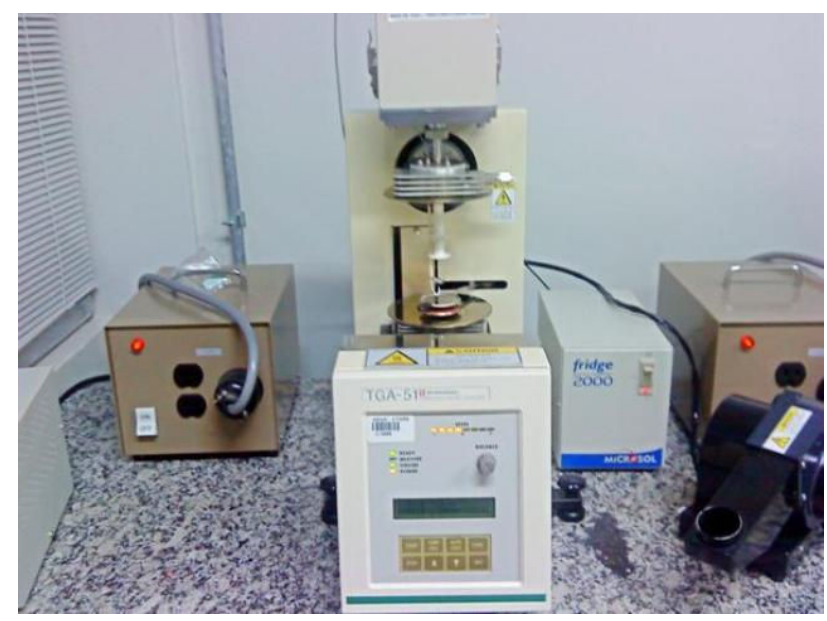

Figura 45: Analisador Termogravimétrico Fonte: Foto do Autor, 2009.

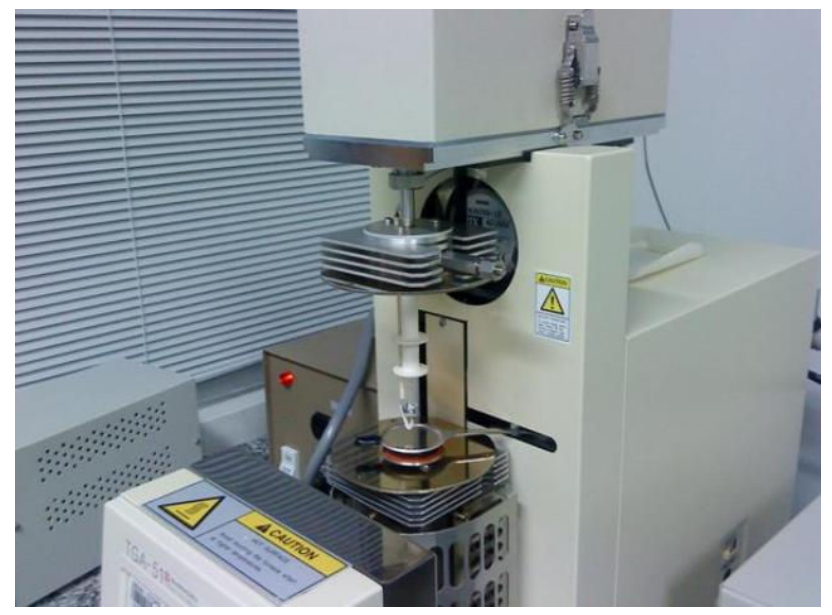

Figura 46: Analisador Termogravimétrico Fonte: Foto do Autor, 2009.

\subsubsection{Ensaio de flexão em três pontos}

O objetivo do ensaio de flexão em três pontos é determinar a resistência última, rigidez (módulo de elasticidade) e deflexão máxima à flexão dos CPS e CPU. Para este ensaio, foi utilizada uma máquina de ensaios mecânicos marca SHIMADZU, modelo AG-1, equipada com dispositivo para ensaio de flexão em três pontos, com célula de carga de $50 \mathrm{KN}$ e uma velocidade de carregamento de 2,0 $\mathrm{mm} / \mathrm{min}$. (Figuras 47 e 48). 
A resistência última à flexão foi definida como sendo a tensão originada da carga responsável pela fratura do corpo de prova. A mesma é medida na superfície inferior (na qual atuam as tensões de tração) do corpo de prova. Todos os ensaios foram realizados à temperatura de $25^{\circ} \mathrm{C}$ e uma umidade relativa do ar de $56 \%$.

Os valores da resistência última à flexão, da rigidez e da deformação máxima foram determinados através das equações normalizadas.

As tensões de flexão e o módulo elástico à flexão dos laminados foram determinados utilizando a norma ASTM D790 (1990).

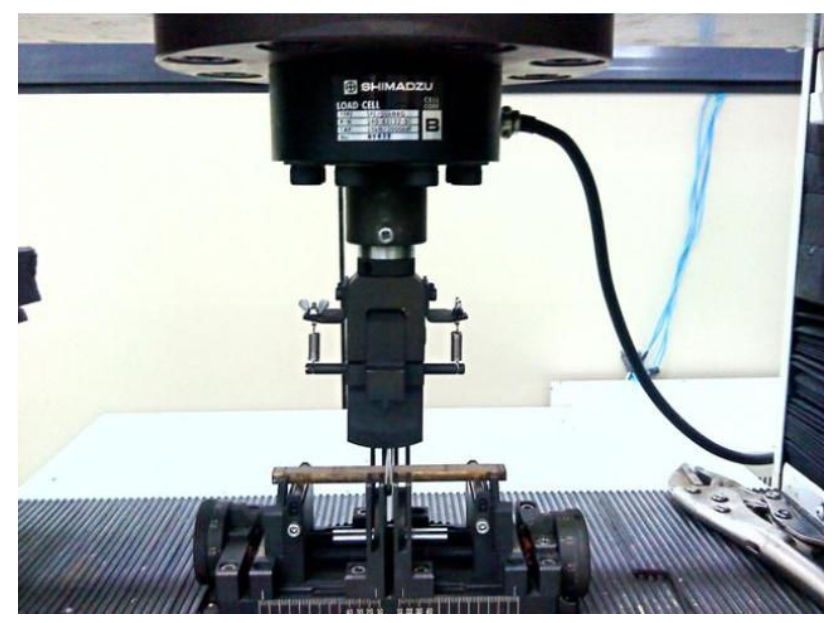

Figura 47: Corpo de prova no início do carregamento Fonte: Foto do Autor, 2009.

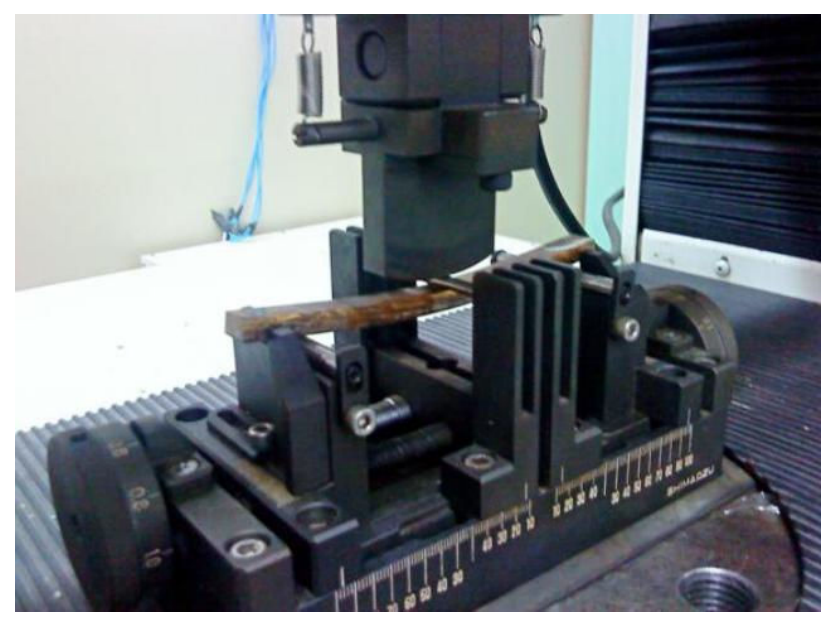

Figura 48: Corpo de prova tensionado Fonte: Foto do Autor, 2009. 


\section{RESULTADOS E DISCUSSÕES}

A expectativa maior deste projeto é possibilitar o desenvolvimento ou a criação de subsídios para que alguma empresa (seja privada ou governamental) desenvolva um compósito de baixo custo, que possa ser utilizado tanto na construção civil como no agronegócio e também na indústria metal mecânico. Busca-se reduzir-se, assim, o gasto com outros componentes que não são biodegradáveis, vindo a contribuir desta maneira para um mundo mais limpo e ambientalmente equilibrado.

São apresentados, a seguir, os resultados obtidos nos ensaios realizados com o compósito estudado e suas pertinentes discussões.

4.1. Ensaios de microscopia eletrônica de varredura (MEV) para as três concentrações de fibras escolhidas.

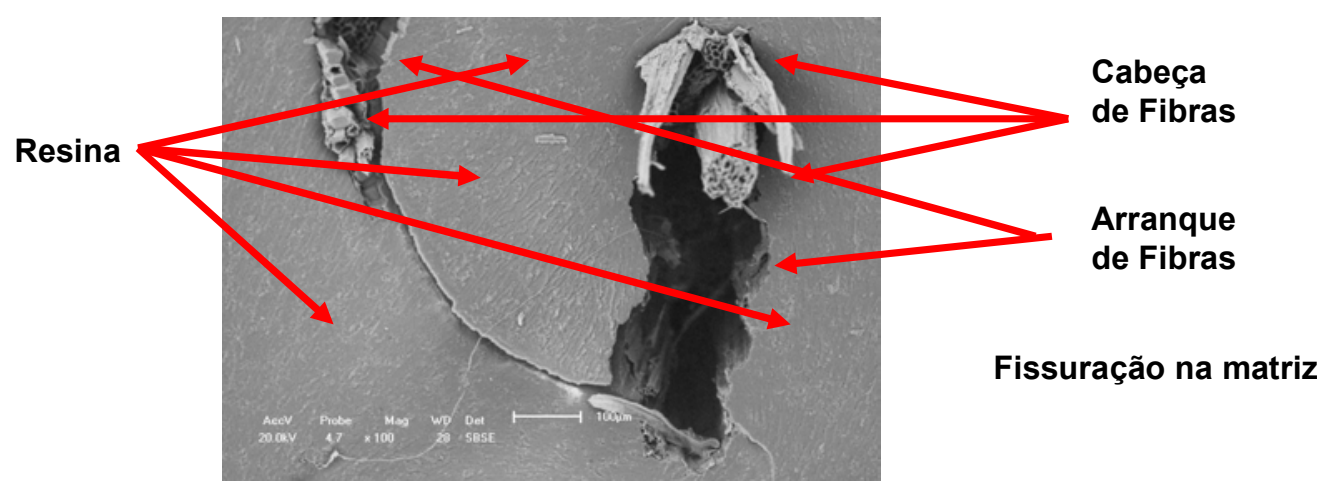

Figura 49: Microscopia eletrônica de varredura (1)

Fonte: Laboratório CTGás.

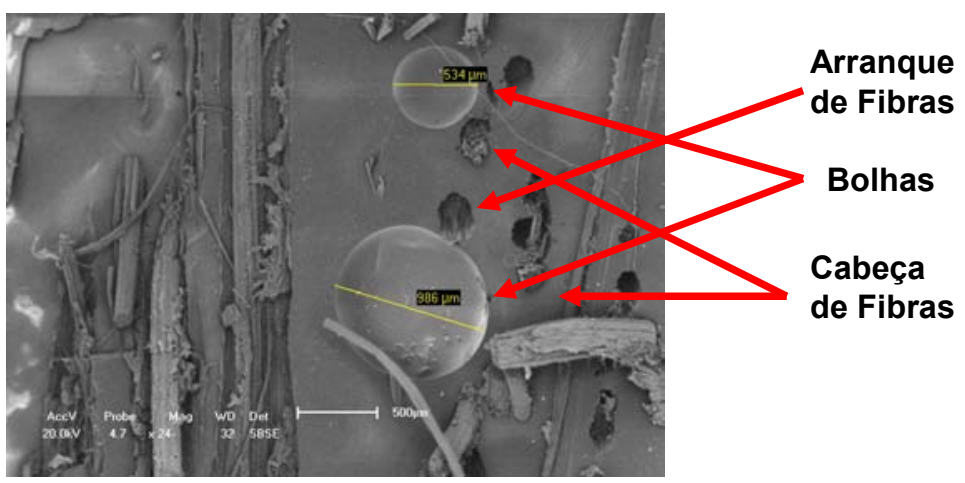

Figura 50: Microscopia Eletrônica de varredura (2)

Fonte: Laboratório CTGás. 


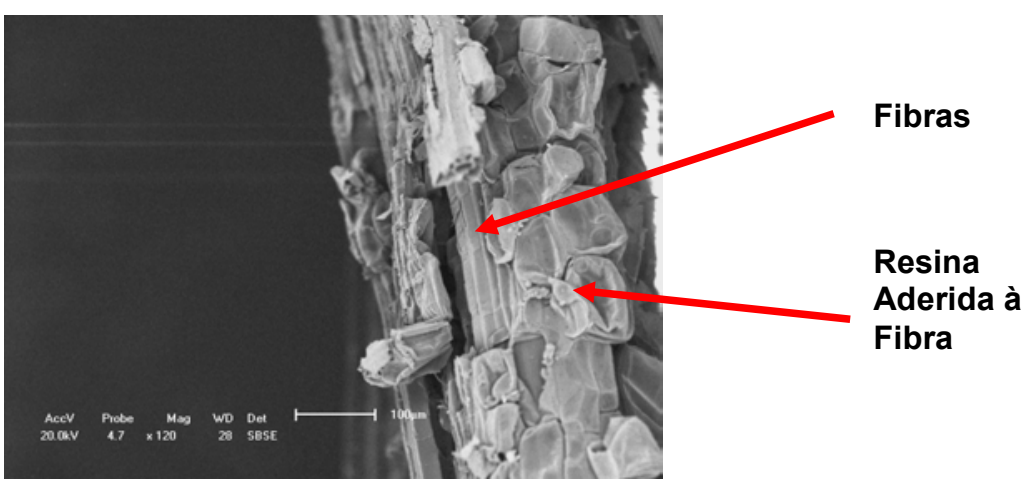

Figura 51: Microscopia Eletrônica de varredura (3)

Fonte:Laboratório CTGás

É possível perceber para as três imagens apresentadas uma fissuração na matriz, com o arranque de fibras. Além disso, pode-se visualizar com nitidez que a fibra partiu-se sem desaderir da matriz.

Entre várias fibras limpas, podem-se perceber bolhas provenientes da laminação manual, o que caracteriza defeitos do processo utilizado para a fabricação do compósito. Torna-se, portanto, necessário uma otimização do processo de fabricação das amostras do compósito.

Aqui, configura-se que a aderência fibra-matriz foi muito boa, caracterizando a fratura sem que, em alguns casos, haja a desaderência entre as mesmas.

\subsection{MICROSCOPIA ELETRÔNICA DE VARREDURA MEV - 9\% DE FIBRAS - TRAÇÃO UNIAXIAL}

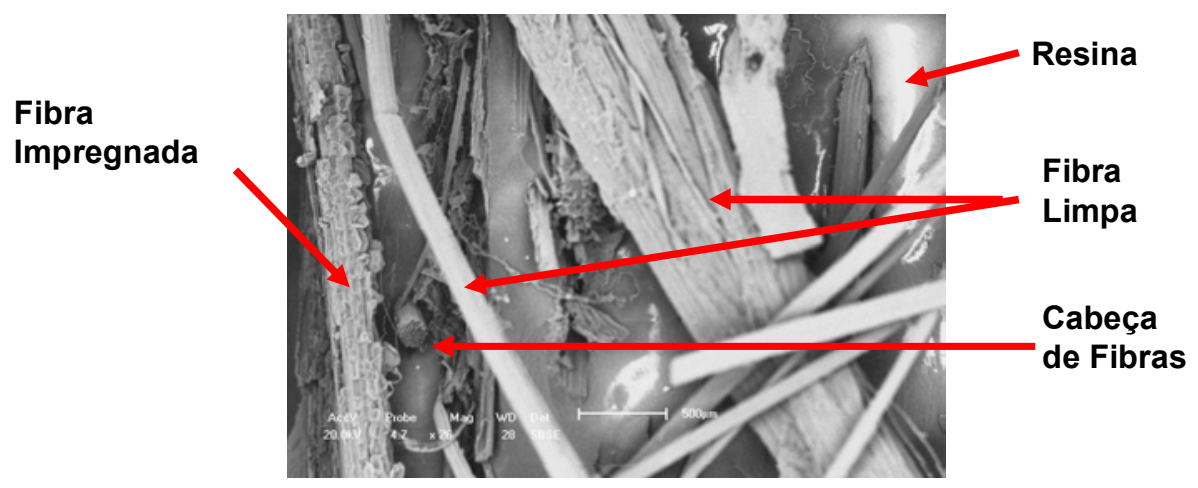

Figura 52: Microscopia Eletrônica de varredura CP 9\% (1)

Fonte: Laboratório CTGás. 


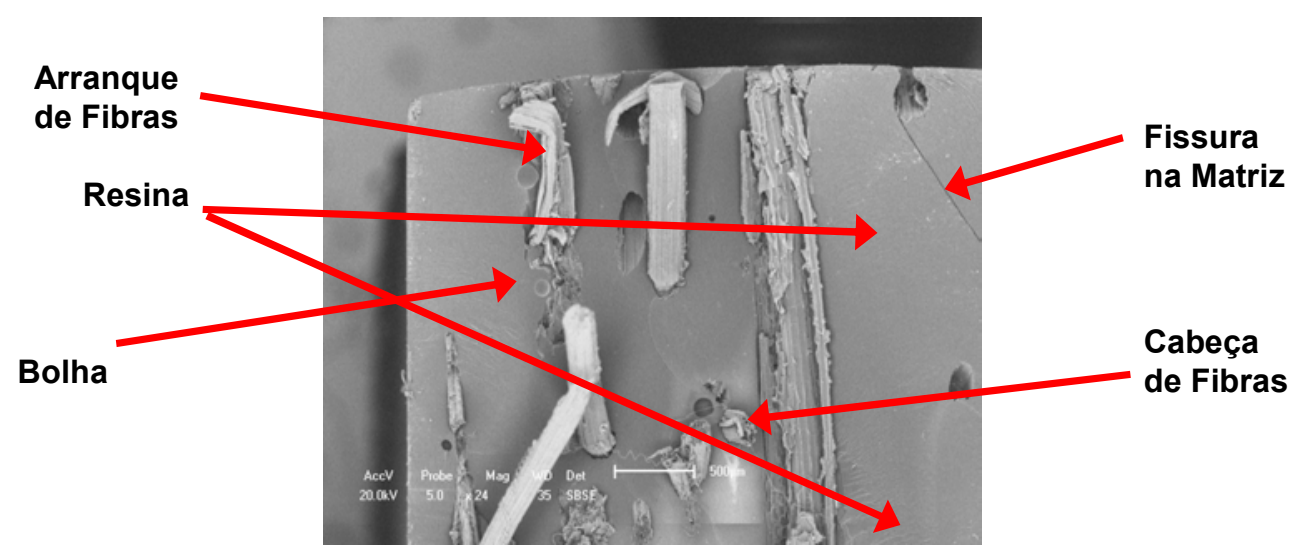

Figura 53: Microscopia Eletrônica de varredura CP 9\% (2)

Fonte: Laboratório CTGás.

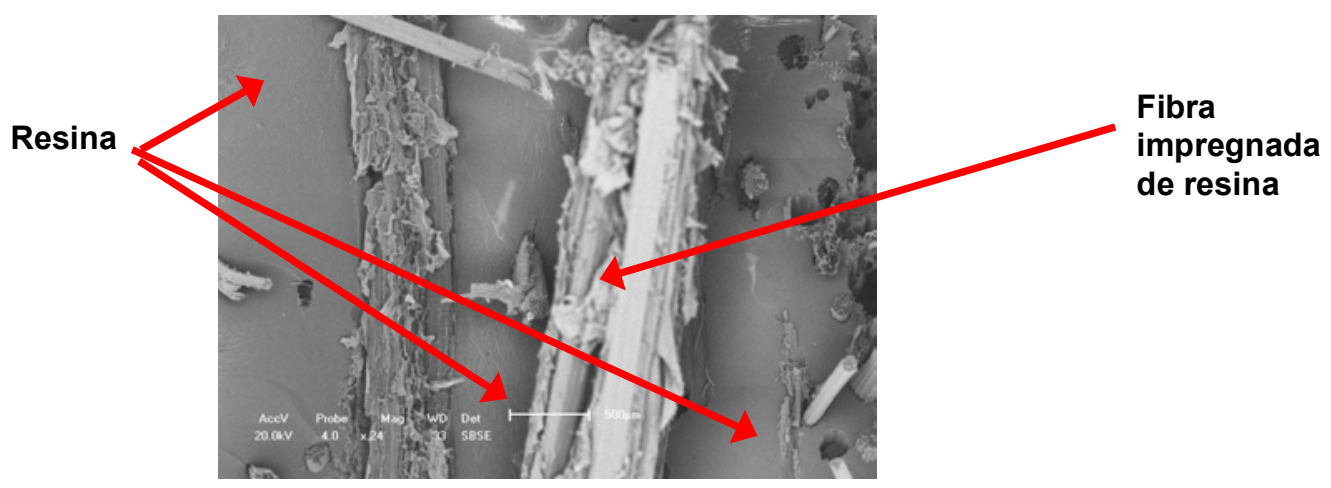

Figura 54: Microscopia Eletrônica de varredura CP 9\%

Fonte: Laboratório CTGás.

\subsection{MICROSCOPIA ELETRÔNICA DE VARREDURA - MEV -} FIBRAS 3\% - TRAÇÃO UNIAXIAL

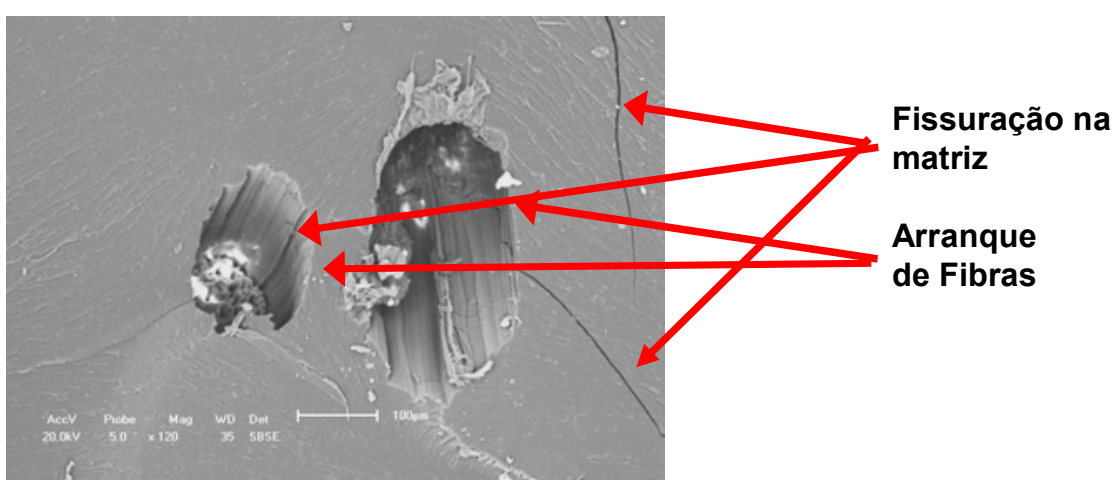

Figura 55: Microscopia Eletrônica de varredura CP 3\%

Fonte: Laboratório CTGás. 


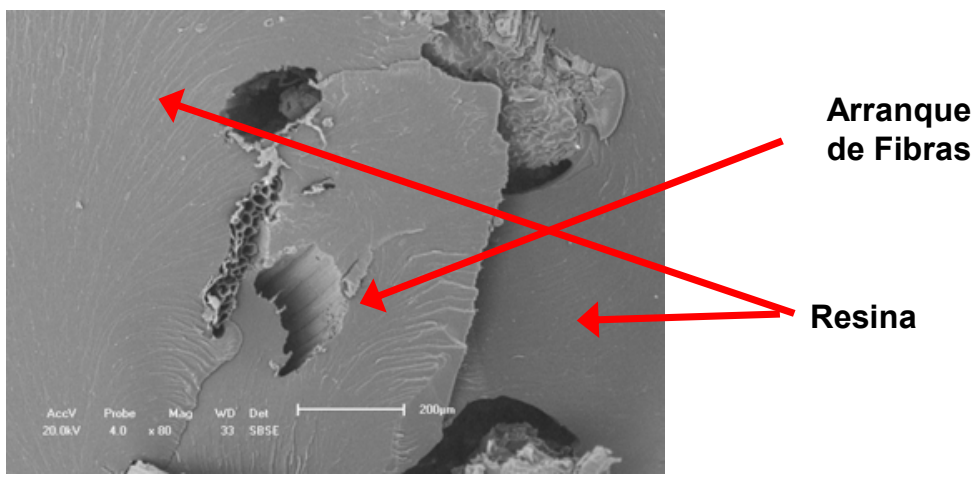

Figura 56: Microscopia Eletrônica de varredura CP 3\% (1)

Fonte: Laboratório CTGás.

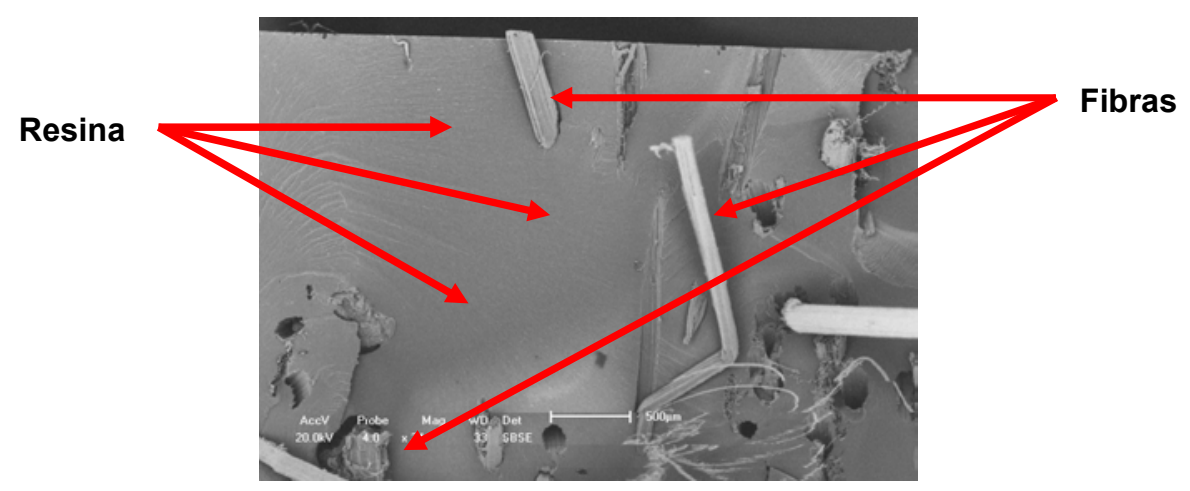

Figura 57: Microscopia Eletrônica de varredura CP 3\% (2)

Fonte: Laboratório CTGás.

\subsection{MICROSCOPIA ELETRÔNICA DE VARREDURA MEV - FIBRAS $6 \%$}

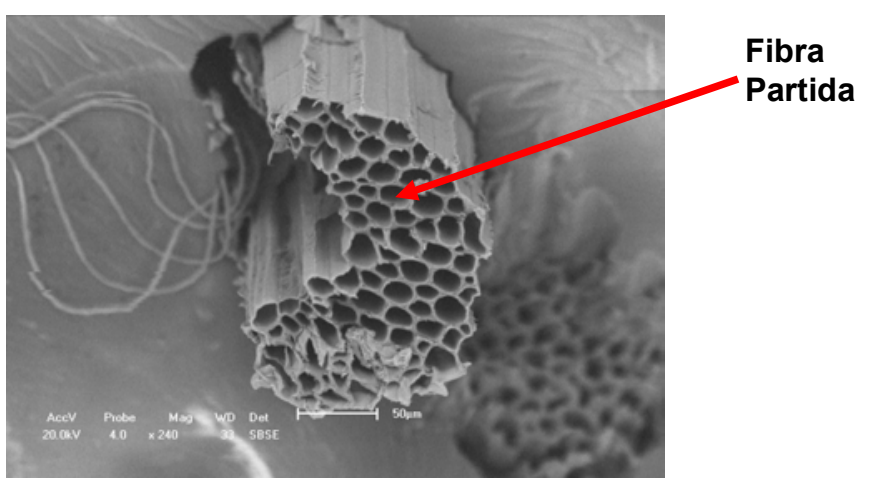

Figura 58: Microscopia Eletrônica de varredura CP 6\% (1)

Fonte: Laboratório CTGás. 


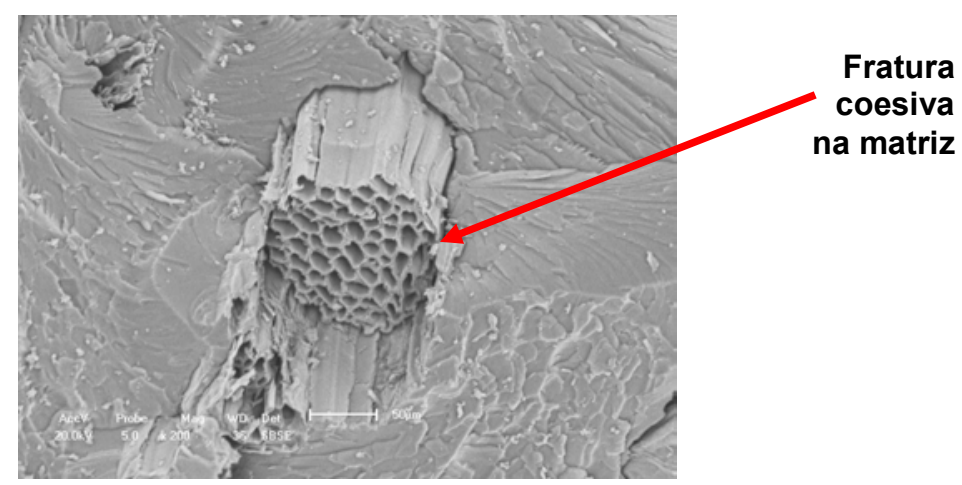

Figura 59: Microscopia Eletrônica de varredura CP 6\% (2)

Fonte: Laboratório CTGás.

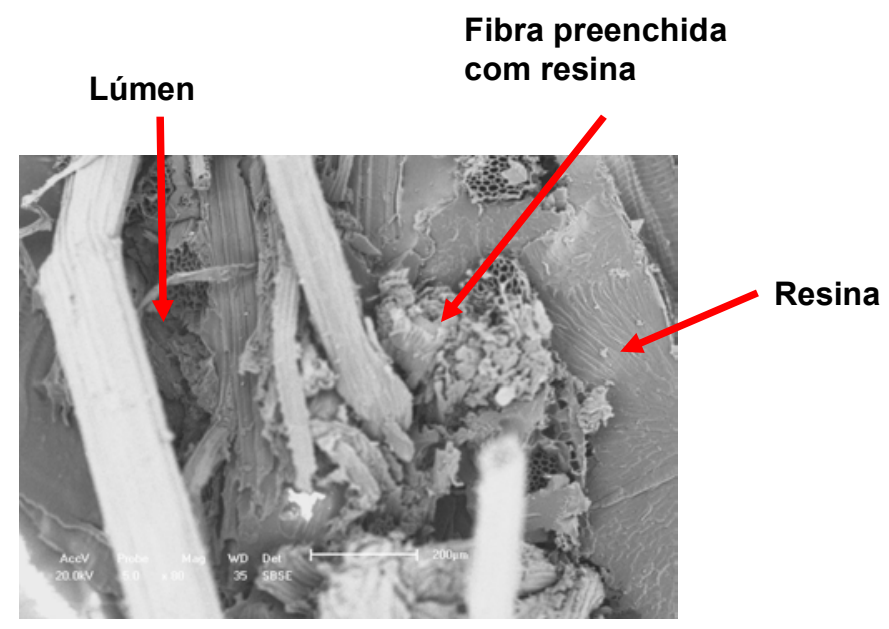

Figura 60: Microscopia Eletrônica de varredura CP 6\% (3)

Fonte: Laboratório CTGás.

4.5. Resultados dos ensaios de flexão em três pontos

As Tabelas 5 e 6 apresentam os resultados dos ensaios de flexão em três pontos para as três concentrações de fibra estudadas, secas e úmidas saturadas e os gráficos das Figuras 61 e 62 o comportamento assumido pela deflexão e módulo de elasticidade. 
Tabela 5: Propriedades mecânicas do compósito seco

\begin{tabular}{c|c|c|c}
\hline \hline PROPRIEDADES & $\mathbf{3 \%}$ & $\mathbf{6 \%}$ & $\mathbf{9 \%}$ \\
\hline $\begin{array}{c}\text { Tensão de flexão } \\
\text { (MPa) }\end{array}$ & 36,8 & 44,0 & 31,8 \\
\hline $\begin{array}{c}\text { Módulo de } \\
\text { elasticidade (GPa) }\end{array}$ & 2,5 & 2,3 & 2,1 \\
\hline \hline
\end{tabular}

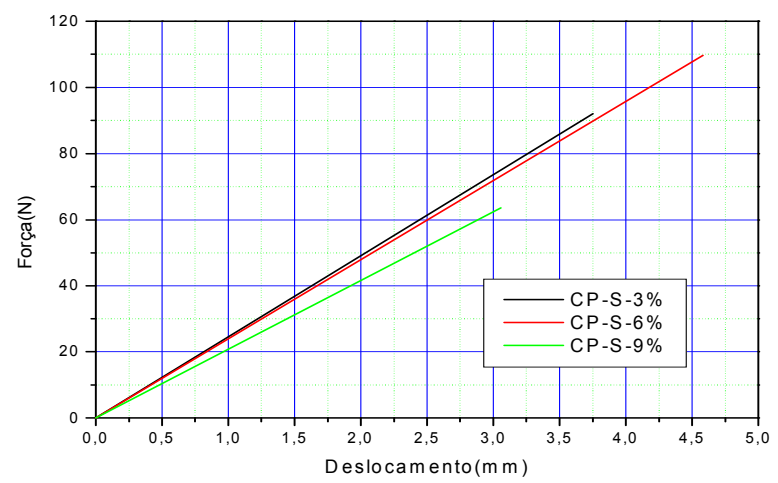

Figura .61 Comportamento médio assumido pelos valores de deflexão.

Tabela 6: Propriedades mecânicas do compósito úmido saturado

\begin{tabular}{c|c|c|c}
\hline \hline PROPRIEDADES & $\mathbf{3 \%}$ & $\mathbf{6 \%}$ & $\mathbf{9 \%}$ \\
\hline $\begin{array}{c}\text { Tensão de flexão } \\
\text { (MPa) }\end{array}$ & 31,0 & 34,4 & 29,0 \\
\hline $\begin{array}{c}\text { Módulo de } \\
\text { elasticidade (GPa) }\end{array}$ & 2,0 & 2,0 & 0,14 \\
\hline \hline
\end{tabular}

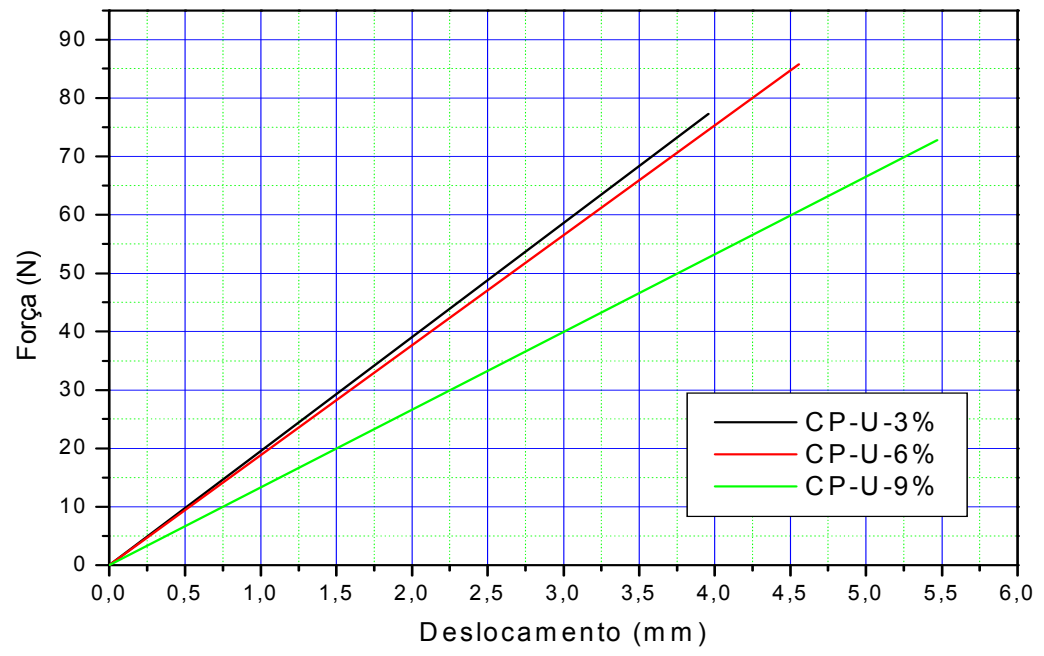

Figura 62: CP Seco: Força X Deflexão 
A Tabela 7 e 8 apresentam os resultados dos ensaios de tração uniaxial para as três concentrações de fibras estudadas, secas e úmidas saturadas e os gráficos das Figuras 63 e 64 mostram o comportamento assumido pela resistência última e módulo de elasticidade.

Tabela 7: Propriedades mecânicas do compósito seco

\begin{tabular}{c|c|c|c}
\hline \hline PROPRIEDADES & $\mathbf{3 \%}$ & $\mathbf{6 \%}$ & $\mathbf{9 \%}$ \\
\hline $\begin{array}{c}\text { Resistência Última } \\
\text { (MPa) }\end{array}$ & 9,2 & 8,4 & 9,3 \\
\hline $\begin{array}{c}\text { Módulo de } \\
\text { elasticidade(GPa) }\end{array}$ & 1,0 & 1,5 & 1,2 \\
\hline \hline
\end{tabular}

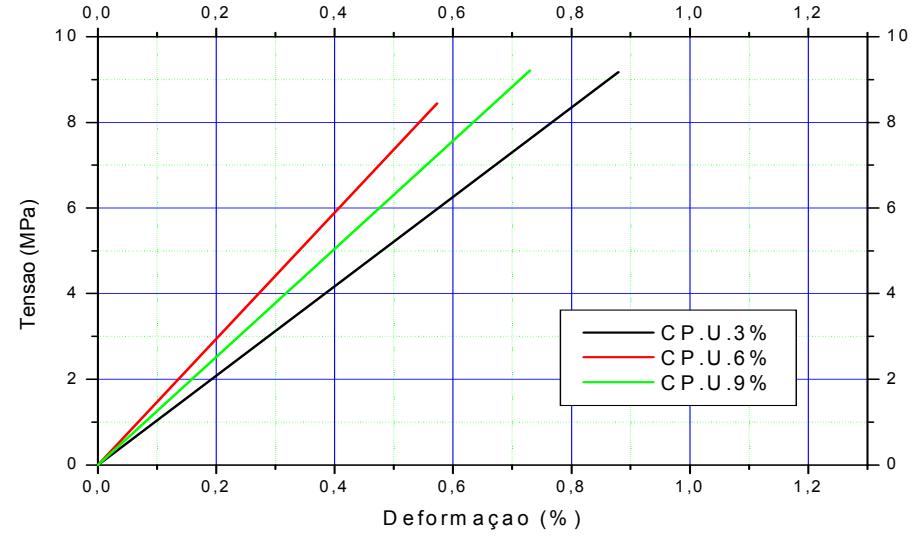

Figura 63: Deformação X Tensão (Valores Médios)

Tabela 8: Propriedades mecânica do compósito úmido saturado

\begin{tabular}{c|c|c|c}
\hline \hline PROPRIEDADES & $\mathbf{3 \%}$ & $\mathbf{6 \%}$ & $\mathbf{9 \%}$ \\
\hline $\begin{array}{c}\text { Resistência Última } \\
\text { (MPa) }\end{array}$ & 9,8 & 9,8 & 11,2 \\
\hline $\begin{array}{c}\text { Módulo de } \\
\text { elasticidade(GPa) }\end{array}$ & 0,7 & 0,7 & 0,8 \\
\hline \hline
\end{tabular}




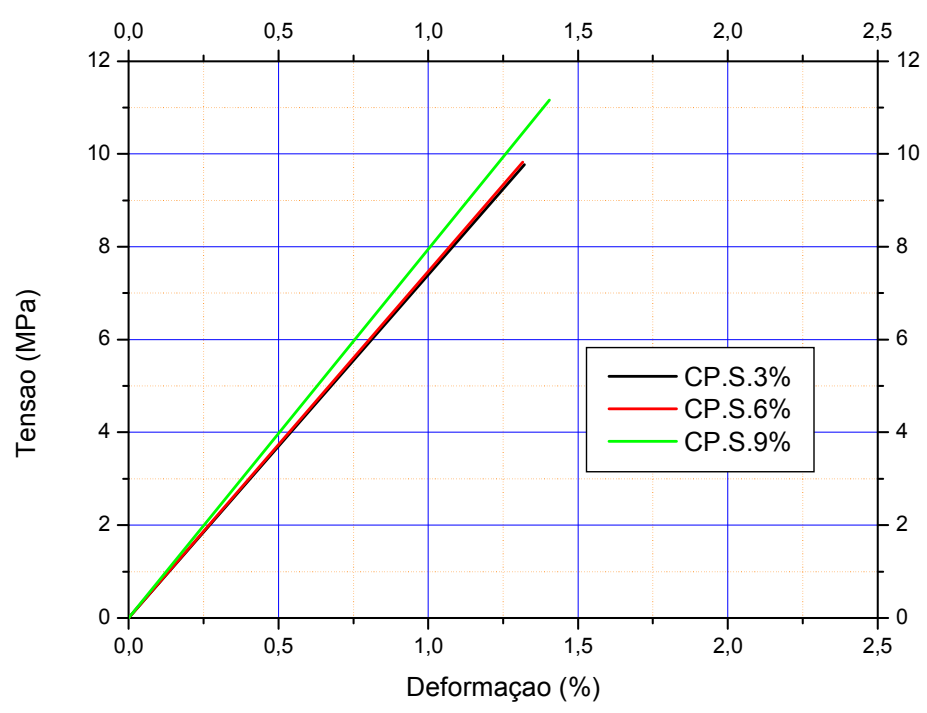

Figura 64: Deformação X Tensão (Valores Médios)

\subsection{GRÁFICOS DE RESULTADOS DA ABSORÇÃO DE UMIDADE}

Os gráficos das Figuras 65,66 e 67 apresentam o comportamento assumido pela massa das amostras, pequenas e grandes, no teste de absorção de umidade para oitenta dias. 


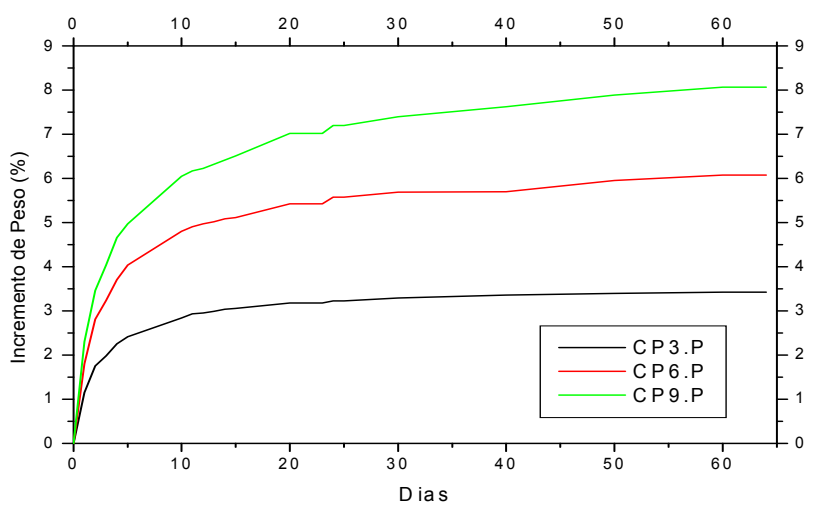

Figura 65: Dias X Incremento de Peso (\%)

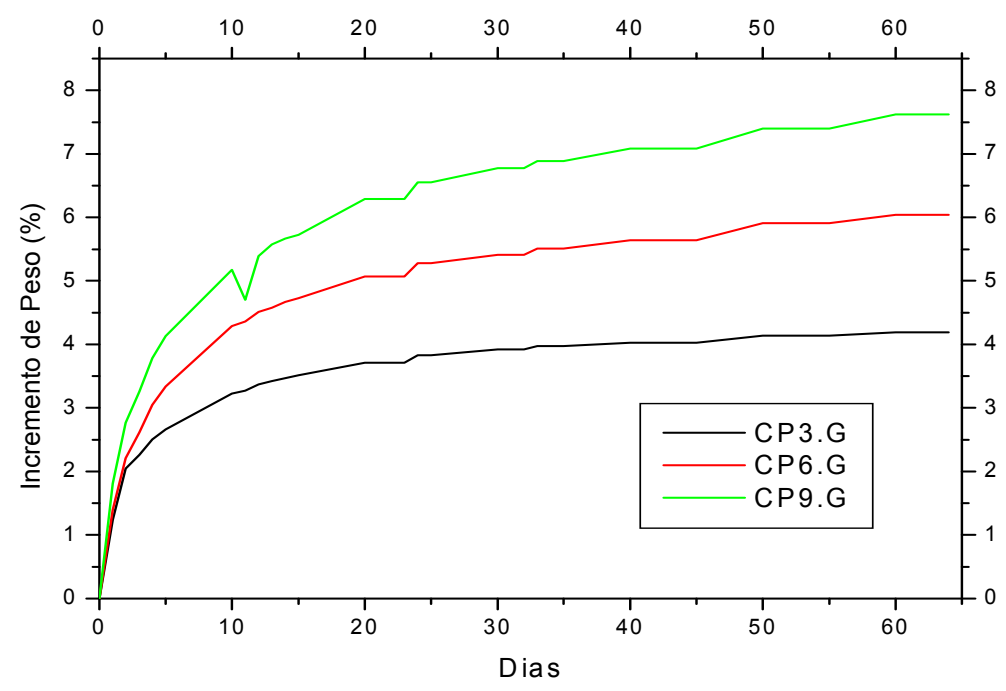

Figura 66: Dias X Incremento de massa(\%) 


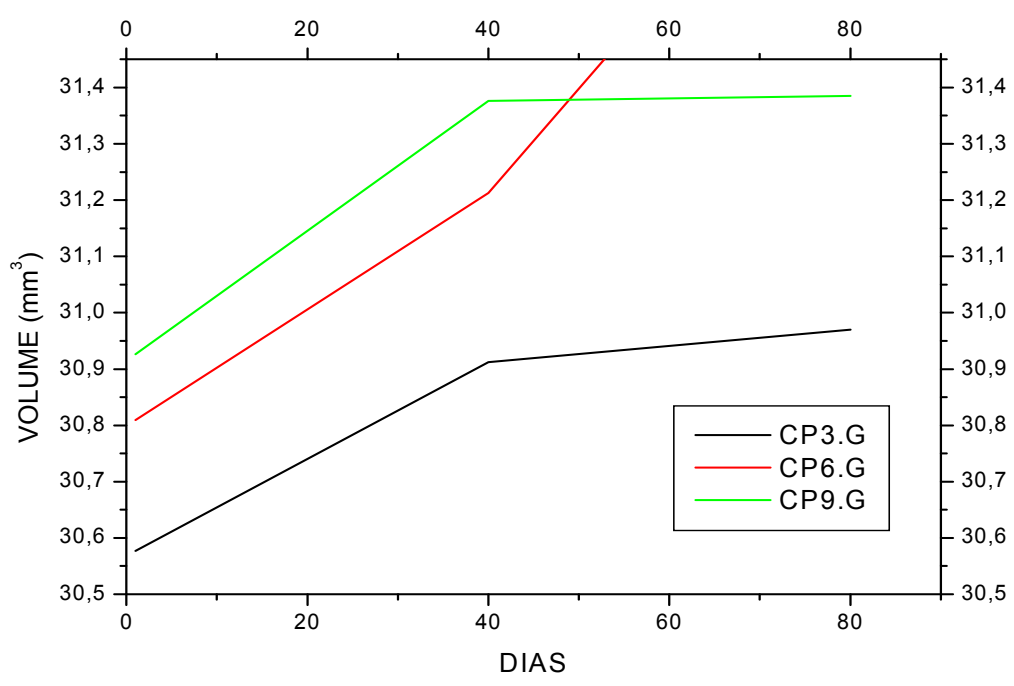

Figura 67: Dias X Volume

Percebe-se que este compósito pode ter uma boa aceitação, pois apresenta rápida saturação indicando que o material pode ser utilizado em locais de alta umidade, como reservatórios, calhas etc. Observou-se, também, que não ocorreram grandes deformações volumétricas e de massa.

Após os 80 (oitenta) dias de realização dos ensaios, com os CPs retirados da água,efetuou-se medições e constatou-se que não ocorreram alterações significativas, o que demonstra que pode ser aplicação onde se exija um controle dimensional mais rígido.

\subsection{GRÁFICOS TERMOGRAVIMÉTRICOS}

Os gráficos das Figuras 68,69 e 90 apresentam o comportamento assumido pelas amostras nos ensaios termogravimétricos para as três concentrações de fibras estudadas. 


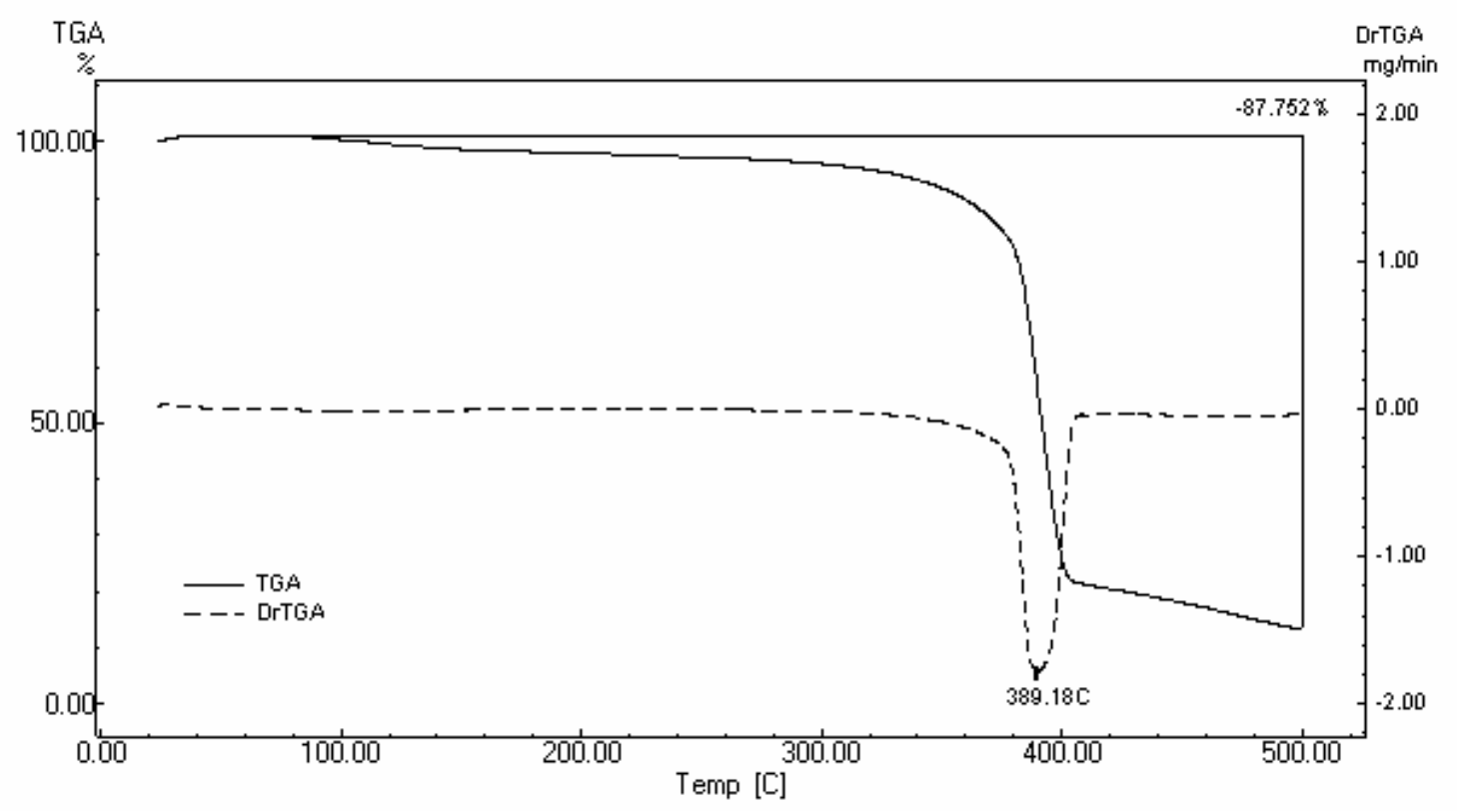

Figura 68: Termogravimétrico CP $3 \%$

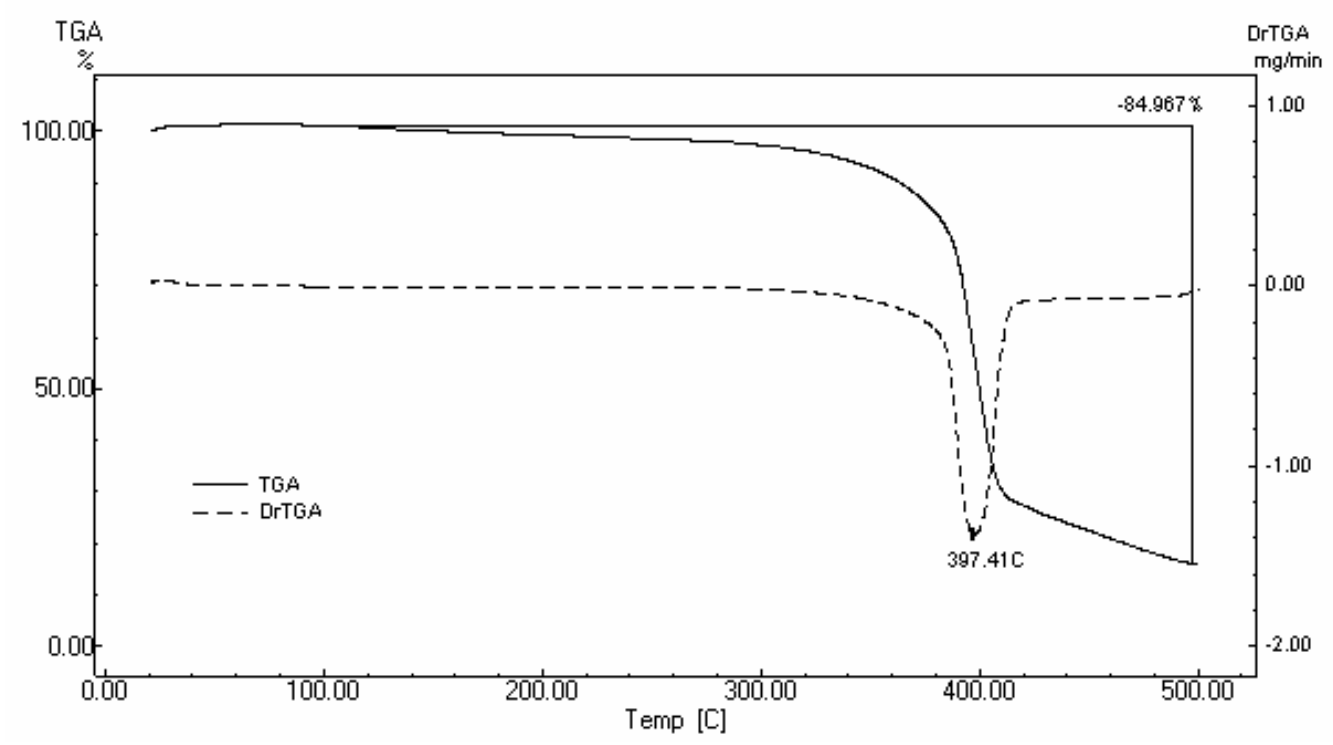

Figura 69: Termogravimétrico CP 9\% 


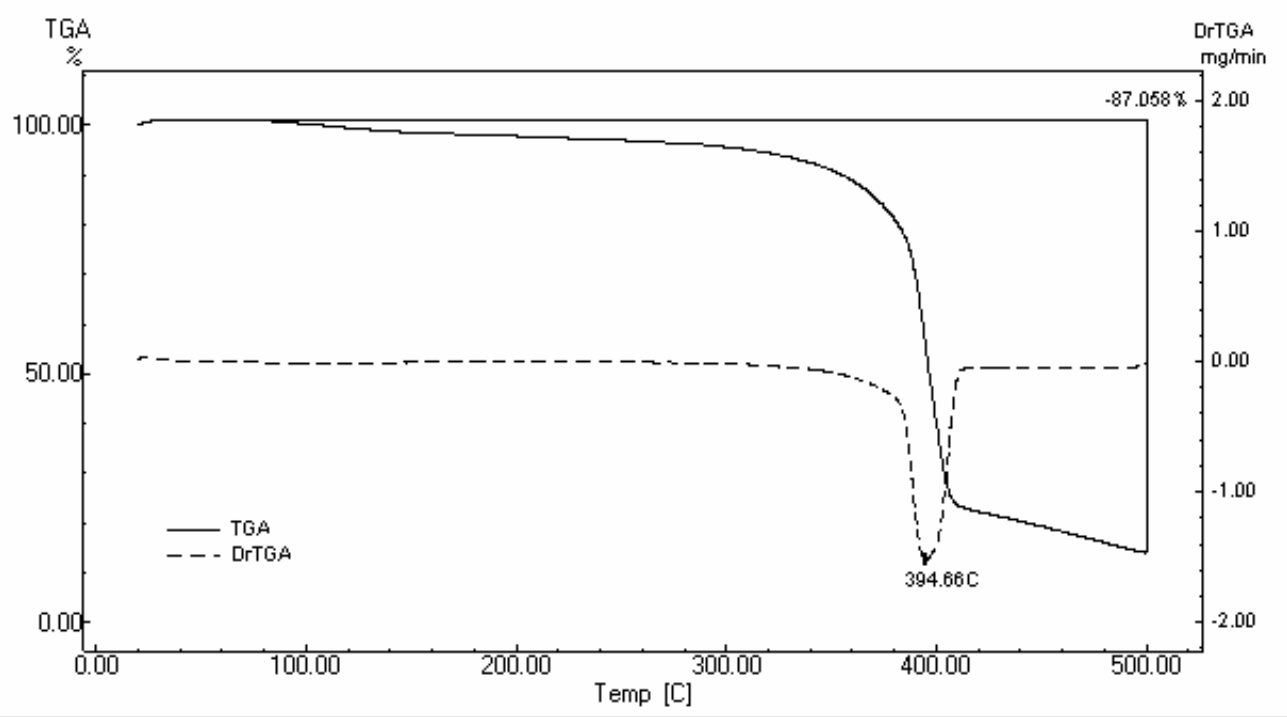

Figura 70: Termogravimétrico CP 6\%

Observou-se que o compósito começou a perder massa a partir de $90^{\circ} \mathrm{C}$ para as concentrações de $3 \%$ e $6 \%$,enquanto para a concentração de $9 \%$ esta temperatura elevou-se para $120^{\circ} \mathrm{C}$.

A partir deste ponto aconteceu um decréscimo lento porém continuo da massa até a perda de aproximadamente $85 \%$ do total a uma temperatura média de $380^{\circ} \mathrm{C}$.

Isso demonstrou que este material pode trabalhar numa faixa de temperatura de $85^{\circ} \mathrm{C}$ sem comprometer a segurança e propriedades. 


\section{CONCLUSÕES}

Apresentam-se, a seguir as conclusões oriundas da análise dos resultados encontrados nesta pesquisa.

- A fibra da bananeira possui uma microestrutura semelhante às demais fibras vegetais;

- Em sua composição microestrutural, pode-se dar destaque ao alto percentual das microfibrilas de celulose, conduzindo a bons resultados nas propriedades mecânicas;

- A fibra apresenta baixo teor de cera, o que facilita o processo de impregnação na obtenção dos compósitos poliméricos;

- Os percentuais de fibras escolhidos foram determinantes nos resultados dos ensaios;

- O módulo de tração da fibra é relativamente baixo, porém possui um alongamento superior às demais fibras que hoje são utilizadas.

- A resistência à tração também possui um valor superior a outras fibras;

- A grande quantidade de fibras nas paredes das cavidades (buracos) na matriz após o ensaio de tração leva a uma boa aderência entre a fibra e matriz;

- O compósito possui boa estabilidade térmica, o que possibilita sua aplicação em temperaturas até $100^{\circ} \mathrm{C}$;

- A fibra possui bom alongamento; 
- Não foram registradas grandes alterações nos resultados dos ensaios de tração e flexão entre os CPs seco e úmido;

- Devido à boa impregnação da fibra, ocorreu uma saturação à umidade com um baixo tempo de imersão;

- O processo de fabricação (Hand Lay Up) influiu diretamente nos resultados, o que foi comprovado pela característica da fratura mecânica no compósito, ou seja, fratura frágil;

- De forma geral, o uso de fibra de bananeira é viável, bastando uma melhoria no processo de obtenção das fibras (mecanização do procedimento) e um maior cuidado na fabricação das peças;

- Caso haja um melhoramento no método de obtenção de fibras (mecanização), ocorrerá a agregação de maior valor ao produto final;

- Este compósito pode ser um diferencial na vida de comunidades carentes e pequenos produtores de banana, pois, devido ao seu baixo custo de fabricação, possui um grande potencial de ser implementado por cooperativas de trabalhadores rurais.

- O compósito com concentração de $9 \%$ de fibra teve um desempenho superior aos demais,embora todos tenha obtidos resultados satisfatórios 


\section{SUGESTÕES PARA TRABALHOS FUTUROS}

- Ampliação dos estudos no compósito reforçado com fibras de bananeira, através de ensaios mais detalhados (comportamento em água salgada, resistência a degradação a raios ultravioleta)etc.

- Desenvolvimento de novas configurações de compósitos, utilizando outras fibras (como o sisal), vindo a constituir-se, com isso, uma composição híbrida.

- Desenvolvimento de novos compósitos com a utilização de outros tipos de resinas, principalmente a epóxi(melhor resistência a umidade).

- Estudo mais detalhado da influência de parâmetros ambientais adversos, como a absorção excessiva de umidade, incidência de raios UV e temperatura nas propriedades dos compósitos reforçados com fibras de bananeira.

- Aplicar o compósito em trabalhos de pesquisa de outros campi e universidades ( parábola de fogão solar,suporte para aquecedores solar de piscina,palhetas de ventiladores) etc. 


\section{REFERÊNCIAS}

AGOPYAN, V.; SAVASTANO JR., H. Uso de materiais à base de fibras vegetais na construção civil: experiência brasileira. in: SEMINÁRIO IBEROAMERICANO 1997 DE MATERIAIS FIBRORREFORZADOS, Y REUNION DEL PROYECTO PIP VIII. 5 cyted, Cali, 1997. Memórias. Cali: Cyted/Universidad del Valle, 1997. p. 23-40.

AL-QURESHI, H. A. Composite Materials: Fabrication and Analysis. $2^{\text {nd }}$. ed. São José dos Campos: ITA, 1983.

AMERICAN SOCIETY FOR TESTING AND MATERIALS. ASTM D3039. Standard Test Methods for tensile Properties of Polymer Matrix composites. Philadelphia: ASTM, 2000.

ASTM D570. Standard Test Methods for Water Absorption of Plastics, Philadelphia: ASTM, 1995.

. ASTM D790. Standard Test Method for Flexural Properties of Unreinforced and Reinforced Plastics and Electrical Insulating Materials. Philadelphia: ASTM, 1990.

ANTEQUERA, P.; JIMENES, L.; MIRAVETE, A. Los Materiales Compuestos de fibra de vidro. Zaragoza, Espana: Universidad de Zaragoza, 1991.

AQUINO E. M. F., et al. Hybrid Composites with Synthetic and Natural Fibers: Degradation by Moisture Absorption, in: COBEM 2005 - 18th INTERNATIONAL CONGRESS OF MEHANICAL ENGINEERING, 2005, Ouro Preto - MG. Proceeding of the COBEM, 2005. v. 01. p. 01-06.

AQUINO E. M. F., et al. Strength/stiffness study in composite laminated tubes. in: SECOND INTERNATIONAL CONGRESS ON METALLURGY AND MATERIALS, São Paulo, 1997. Annals. v. 1, p. 1-8, São Paulo, 1997.

AQUINO, E. M. F. Estudo da umidade na resistência e fratura de compósitos tubulares. in: IV CONGRESSO DE ENGENHARIA MECÂNICA N/NE, jun., 1996, Recife. Anais ABCM, Recife, 1996.

AQUINO, E. M. F. Identificação do modo de fratura de compósitos poliésteres Vidro-E. in: $13^{\circ}$. CBCIMAT. CONGRESSO BRASILEIRO DE ENGENHARIA E CIÊNCIAS DOS MATERIAIS, Curitiba /PR - BR, 1998. Anais... v. 1, Curitiba, 1998.

AQUINO, E. M. F.; OLIVEIRA, W. Compósitos Híbridos de Fibras de Vidro, Juta e Curauá: Comportamento Estático e Mecanismo de Dano. in: CONGRESSO BRASILEIRO DE ENGENHARIA E CIÊNCIAS DOS MATERIAIS - CBECIMAT/2004, 2004, Porto Alegre/RS. Anais.. v. 01. p. 01-10, Porto Alegre, 2004.

ARAÚJO, M.; CASTRO, E. M. M. Manual de engenharia têxtil. Lisboa: Fundação Calouste Gulbenkian, 1984. 
ASSOCIAÇÃO BRASILEIRA DE MATERIAIS COMPÓSITOS - ABMACO. Quem Somos. Disponível em: <http://www.abmaco.org.br/quemsomos.cfm>. Acesso em: 21 out. 2009.

ASSOCIAÇÃO BRASILEIRA DE NORMAS TÉCNICAS. NBRs 6023, 6024, 6027, 6028, 10520, 10719, 14724: informação e documentação: referências; numeração progressiva das seções de um documento escrito; sumário; resumo; citações em documentos; apresentação de relatórios técnico-científicos; trabalhos acadêmicos: elaboração apresentação. Rio de Janeiro: ABNT, 2006.

ATHENAS ISOLANTES TÉRMICOS. Cordas, cordões, gaxetas. Disponível em: <http://www.athenas-jm.com.br/isolantes/cordas.htm>. Acesso em 25 maio 2007.

BALZER, P. et al. Estudo das Propriedades Mecânicas de um Composto de PVC Modificado com Fibras de Bananeiras. Polímeros, São Carlos, v. 17, n. 1, jan/mar, 2007. Disponível em: <http://www.scielo.br/scielo.php?script=sci_arttex\&pid=S0104142>. Acesso em: 06 ago. 2008.

BLEDSKI, A. K.; GASSAN, J. Composites Reinforced with Cellulose Based Fibers. Porg. Polym. Sci., 24, 1999, p. 221-274,.

BONFIM, R. F. S. Fibras sintéticas e o futuro da economia da juta. Manaus: SUDAM, 1968.

CALLISTER JR., W. D. Materials Science and Engineering: an Introdution. $3^{\text {thd }}$ ed. New York: John Wilen Sons, Inc., 1994.

COELHO, Robson Rogério Pessoa; MATA, Mário Eduardo R. M. Cavalcanti; BRAGA, Maria Elita Duarte. Alterações dos componentes nutricionais do pseudocaule da bananeira quando processado visando sua transformação em palmito. Revista Brasileira de Produtos Agroindustriais, Campina Grande-PB, v.3, n.1, p.21-30, 2001.

COMPANHIA AMBIENTAL DO ESTADO DE SÃO PAULO. Hexano. São Paulo: Secretaria de Estado do Meio Ambiente, 2001. Disponível em:

<http://www.cetesb.sp.gov.br/emergencia/produtos/ficha_completa1.asp?consulta=H EXANO>. Acesso em: 12 set. 2009.

COMPANHIA BRASILEIRA DE CARTUCHOS. Coletes balísticos e equipamentos. CBC: Ribeirão Pires - SP, 2009. Disponível em:

<http://www.cbc.com.br/userfiles/img_colete_multi.png>. Acesso em: 12 set. 2009.

CORREIA, A. Z. Métodos e Processos para Fabricação de Materiais

Compósitos. São Paulo: EMBRAER, 1988.

COSTA, R. Compósitos poliéster-juta: efeitos de modificações químicas no reforço e na matriz poliéster. 1997. 137 f. Dissertação (Mestrado em Engenharia Mecânica), Universidade Federal da Paraíba, João Pessoa. 
DAVIES, P.; PETTON, D. An experimental study of scale effects in marine composites. composites Part A. Applied science and manufacturing. v. 30. pp. 267-275, 1999.

DONATO, Sérgio Luiz Rodrigues et al. Comportamento de variedades e híbridos de bananeira (Musa spp.), em dois ciclos de produção no sudoeste da Bahia. Rev. Bras. Frutic., Jaboticabal, v. 28, n. 1, abr. 2006. Disponível em: $<$ http://www.scielo.br/scielo.php?script=sci_arttext\&pid=S0100$29452006000100039 \&$ Ing=en\&nrm=iso>. Acesso em: 13 set. 2009.

ENGLISH, B.; CLEMEONS, C. M.; STRAK, N.; SCHNEIDER, J. P. Waste-WoodDerived Fillers for Plastics. USDA Forest Service Forest Products Laboratory General Technical Report. FPL-GTR 91, 1996.

FELIPE, R. N. B. Moldagem a vácuo de plástico reforçado. Parâmetros de controle e propriedades dos moldados em PRFV. 1997. 107 f. Dissertação (Mestrado em Engenharia Mecânica), Universidade Federal do Rio Grande do Norte, Natal.

FENGEL, D.; WEGENER, G. Wood: chemistry, ultra structure, reactions. Berlin: Walter de Gruyter, 1989.

FONSECA, V. M. Estudo comparativo das propriedades mecânicas em compósitos poliéster/sisal quimicamente tratado. 1998. 81 f. Dissertação (Mestrado em Engenharia Mecânica), Universidade Federal do Rio Grande do Norte, Natal.

FREIRE JÚNIOR, R. C. S. Estudo da prevenção de falha por fadiga em laminado de plástico reforçado com fibras de vidro. 2001. 133 f. Dissertação (Mestrado em Engenharia Mecânica), Universidade Federal do Rio Grande do Norte, Natal.

GASSAN, J.; BLENDZKI, A. K. The influence of fiber-surface treatment on the mechanical properties of jute-polypropylene. Polymer Composites, v. 28A, p. 10011005, 1997.

GAUTHIER, R.; JOLY, A. C. C.; GAUTHIER, H.; ESCOUBES, M. Interfaces in polyolefin/cellulosic fiber composites: chemical coupling, morphology, correlation with adhesion and aging in moisture. Polymer Composites, v.19, n. 3, p. 287-300, 1998.

GU, J.; WU, H. F.; KAMPE, S. L.; LU, G. Q. Volume fraction effects on interfacial adhesion strength of glass-fibers polymer composites. Materials Science and Engineering, v. 277A, p. 237-243, 2000.

GUIMARÃES, Guilherme Pinto. Uma Formulação de Elementos Finitos Axissimétricos para Análise de Tubos Laminados em Materiais Compósitos. 2006. 120 f. Dissertação (mestrado em Engenharia Mecânica), Pontifícia Universidade Católica do Rio de Janeiro; Departamento de Engenharia. Rio de Janeiro. Orientador: Carlos Alberto de Almeida. 
HAGE JÚNIOR, E. Compósitos e blends poliméricas. Campinas: Instituto latinoamericano e IBM Brasil, 1989.

HAMELIM, P. Comportement Mecànique des Materiaus et des structures Composites - Application au Dimensionnement et à la Conception de Pieces Composites. Cooperation Scientique et Technique Franco-Vietnamience. Materiaus Macromoleculaires et composites, 1988.

HERAKOVICH, C. T. Mechanics of Fibrous Composites. New York: John Viley \& Sons, Inc., 1997.

HIMMERFARD, D. Fiber Vegetable. Encyclopedia of Polymer And Tecnology. New York: John Willey and Sons Inc., 1969. p. 619-712.

HOMMA, A. K. O. A civilização da juta na Amazônia: expansão e declínio. in: Amazônia: meio ambiente e desenvolvimento agrícola. Brasília: Embrapa/SP, 1998.

HULL, D. An Introduction to Composite Materials. Cambridge: Cambridge University Press, 1988.

INOVAÇÃO TECNOLÓGICA. Cientistas criam fibras a partir de nanotubos. Nanotecnologia, 25 jun. 2003. Disponível em: <http://www.inovacaotecnologica.com.br/noticias/noticia.php?artigo=010160030625> . Acesso em: 13 nov. 2009.

INSTITUTO DE PESQUISAS TECNOLÓGICAS - IPT. Celulose e Papel. Tecnologia da Fabricação de Pasta Celulósica. v. 1. 2. ed. São Paulo: IPT, 1988.

JAIGOBIND, Allan George A.; AMARAL, Lucia do; JAISINGH, Sammay. Fabricação de peças em fibra de vidro (compósitos). Dossiê Técnico. Curitiba: Instituto de Tecnologia do Paraná. Serviço Brasileiro de Respostas Técnicas - SBRT, 2007. Disponível em: <http://www.sbrt.ibict.br>. Acesso em: 25 jul. 2007.

JOLY, C; M.; KOFMAN, R.; GAUTHIER. Polypropylene/Cellulosic Fiber Cmposites: Chemical treatment of the Cellulose Assuming Compatibilization Between 22 the two Materials. J. Pure Appl. Chem. A33 (12): 1981-1996.

JOSEPH, P. V.; MATHEW, G.; JOSEPH, K.; GROENINCKX, G.; Thomas, S. Dynamic mechanical properties of short sisal fiber reinforced polypropylene composites. Composites: Part A, v. 34. p. 275-290, 2003.

KELLY, A.; MILEIKO, S. T. Fabrication of Composites. v. 4. Nort Holland: Handbook of Composites, 1983.

KOZLOWSKI, R.; MIELENIAK, B.; PRZEPIERA, A. Plant Residues as Raw Materials for Particleboards. Pozna, Poland: Institute of Natural Fibers, April 12-14, 1993. 
LANTOR COREMAT. Homepage. Disponível em: <http://www.lantor.nl>. Acesso em: 31 maio 2007.

LEÃO, Mirtânia Antunes. Fibras de licuri: um reforço alternativo de compósitos poliméricos. 2008. 109 f. Dissertação (Mestrado em Engenharia Mecânica). Universidade Federal do Rio Grande do Norte, Natal. Orientadores: Profa ${ }^{a}$. Dra. Eve Maria Freire de Aquino; Prof. Dr. Raimundo Carlos Silvério Freire Júnior.

MALLICK, P. K. Fiber-reinforced composites: materials, manufacturing and design. New York: Marcel Dekker, 1988.

MANO, E. B. Polímeros como materiais de engenharia. São Paulo: Edgard Blucher, 1991.

MARGARIA, G., AQUINO, E. M. F. Influence of moisture on the mechanical properties of polyester/fibre glass-E composite. in: INTERNATIONAL CONGRESS ON METALLURGY AND MATERIALS, 2. São Paulo, 1997. Anais... São Paulo, 1997.

MATTHEWS, F. L.; RAWLINGS, R. D. Composite materials: engineering and science. London: Chapman \& Hall, 1994.

MECÂNICA ONLINE. Ford é pioneira em utilizar Sisal no interior dos veículos. Revista Multimídia, Recife, n. ${ }^{\circ} 109$, jan. 2009. Disponível em: <http://www.mecanicaonline.com.br/2009/1\%2Bjaneiro/2\%2Btecnovidade/ford\%2Bsi sal.htm>. Acesso em: 25 set. 2009.

MENDES, T. M. F. F. Propriedades de Resistência à Tração e ao Impacto de Compósitos Poliéster Sisal: Um estudo Comparativo. 1992. 123 f. Dissertação (Mestrado em Engenharia Mecânica). Universidade Federal do Rio Grande do Norte, Natal.

MITRA, B. C.; BASAK, R. K.; SARKAR, M. Studies on Jute-reinforced composites, its limitations, and some solutions through chemical modifications of fibers. Journal of Applied Polymer Science, v. 67, n. 6, p. 1093-1100, 1998.

MOHANTY; K.; MISTRA, M. Studies on jute fibers in composites: a literature review. Polymer Plastic Tecnology Engeering, v. 34, n.5, p. 729-792, 1995.

MONTEIRO, Sérgio; TERRONES, Luiz A. H.; CAMERINI, Amanda L. Propriedades de compósitos de tecido de juta descartado reforçando matriz de polietileno reciclado. Matéria, Rio de Janeiro, 2006, vol. 11, n. ${ }^{\circ} 4$, pp. $403-411$.

NAIK, N. K.; KUMAR, R. S. Compressive Strength of Unidirecional Composites: Evaluation and comparison of Prediction Moldes. Composite Structures, v. 46, p. 299-308, 1999.

NATICURSO. Homepage. <http://www.naticurso.com.br>. Acesso em: 25 maio 2007. 
NEVES, José Henrique. Análise da Integridade Estrutural do Quartzito Itacolomi Colado com Diferentes Resinas. 2006. 87 f. Dissertação (Mestrado em Engenharia de Materiais. Universidade Federal de Ouro Preto, UFOP, Ouro Preto, MG.

Orientador: Luiz Cláudio Cândido.

NOTHENBERG, M. Cresce o interesse pelo uso de fibras naturais. Revista Plástico Moderno, QD. Ltda., nº. 263, p. 6-15, 1996.

OLIVEIRA, J. F. S.; AQUINO, E. M. F.; SILVA, R. V. Configurações alternativas no uso dos PRF: laminado e estrutura sandwich. Trabalho aceito para apresentação no $19^{\circ}$ Congresso de Engenharia Mecânica - COBEM, em novembro de 2007 (no prelo).

OLIVEIRA, Jorge Fernando de Sousa Estudos da influência da configuração em compósitos poliméricos híbridos. 2007. Dissertação (Mestrado em Engenharia Mecânica). Universidade Federal do Rio Grande do Norte, Natal. Orientadores:

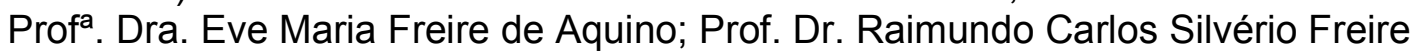
Júnior.

OLIVEIRA, M. H. Principais matérias-primas utilizadas na indústria têxtil. BNDES Setorial, Rio de Janeiro, n. 5, p. 71-109, mar. 1997.

OXFORD UNIVERSITY. Safety data for hexane. Londres: The Physical and Theoretical Chemistry Laboratory, 2005. Disponível em:

<http://msds.chem.ox.ac.uk/HE/hexane.html>. Acesso em: 12 set. 2009.

PACHECO, E. B.; SANTOS, M. S.; DIAS, M. L. Materiais Reciclados à Base de PET e Cargas de Coco. Águaonline - Revista digital da água, do saneamento e do meio ambiente, Rio de Janeiro, n. ${ }^{\circ} 149$, fevereiro de 2003. Disponível em: <http://www.niead.ufrj.br/artigoelen3.htm>. Acesso em: 12 out. 2009.

PAIVA, J. M. F.; FROLLINI, E. Matriz termofixa fenólica em compósitos reforçados com fibras de bagaço de cana-de-açúcar. Polímeros: Ciências e Tecnologia, Abr/Jun, 1999, pp. 78 - 87.

PAIVA, J. M. F.; TRINDADE, W. G.; FROLLINI, E. Compósitos de matriz termofixa fenólica reforçados com fibras vegetais. Polímeros: Ciências e Tecnologia Out./Dez. 1999. p. 170-76.

PAIVA, M. F. Jane et al. Compósitos de Matriz Termofixa Fenólica Reforçadas com Fibras Vegetais. Polímeros, São Carlos, v. 09 n. 4., out./dez., 1999. Disponível em: $<$ http://www.scielo.br/scielo.php?pid=S0104-

14281999000400028\&script=sci_artetext\&tlng>. Acesso em: 21 jul. 2008.

PIMENTA, M. J. A.; FROLLINI, E. Lignin: utilization as a "macromonomer" in the synthesis of phenolic type resins. Anais da Associação Brasileira de Química, v.46, n.1, 1997, p.43-49. 
PROGRAMA EDUCAR. Classificação de polímeros. São Paulo: Universidade de São Paulo, 2003. Disponível em: <http://educar.sc.usp.

br/licenciatura/2003/quimica/paginahtml/polimeros3.htm>. Acesso em: 23 out. 2009.

RANA, A. K.; MANDAL, A.; MITRA, B. C.; JACOBSON, R.; BANERJEE, A. N. Short jute fiber-reinforced polypropylene composites: effetc of compatibilizer. Journal of Applied Polymer Science, v.6, 1998, n. 2, p. 329-338.

REBENFIELD, L.; Fiber. Encyclopedia of Polymer And Tecnology. New York: John Willey \& Sons Inc., 1969, p. 522-533.

REIFSNIDER, K. L.; TALUG, A. Analysis of Fatigue Damage in Composite laminates. International Journal of Fatigue, jan. 1980, p. 3-11.

ROWELL, R. M. Opportunities for Lignocellulosic Materials and Composites. in: EMERGING TECHNOLOGIES FOR MATERIALS AND CHEMICALS FROM BIOMASS: PROC. OF SYMPOSIUM; 1990, August 26-31; Washington, DC. Washington, ACS Symposium Series 476. DC: American Chemical 21 Society; 1990. Chap. 2. p. 12-27.

ROWELL, R.M.; SANADI, A.R.; CAULFIED, D. F.; JACOBSON, R. E. Utilization of natural fibers in plastic composites: problems and opportunities. in:

LIGNOCELLULOSIC - Plastics Composites. São Paulo: USP/UNESP, p. 23-51, 1997.

SAINT GOBAIN VETROTEX. Processos. 2007. Disponível em: <http://www.saintgobainvetrotex.com.br/portugues/process_list.html>. Acesso em: 31 maio 2009.

SCHUH, T.; GAYER, U. Automotive applications of natural fiber composites. Benefits for the environment and competitiveness with man-made materials. in: LEÃO, A. L.; CARVALHO. F. X.; FROLLINI, E. (Eds.) Lignocellulosic-plastics composites. São Paulo: USP, 1997, p.181-195.

SILAEX QUÍMICA. Poliéster Insaturado. São Paulo, 2006.

<http://www.silaex.com.br/poliéster.htm>. Acesso em: 29 set 2009.

SILVA, Rosana Vilarim da. Compósito de resina poliuretano derivada do óleo de mamona e fibras vegetais. 2003. $157 \mathrm{f}$. Tese (Doutorado Engenharia de Materiais). Universidade do Estado de São Paulo - USP, São Carlos.

SREEKALA, M. S., JAYAMOL, M. G.; KUMARAN, S. T. The mechanical performance of hybrid phenol-formaldehyde - based composites reinforced with glass and oil palm fibres. Composites Science and Technology, 62 (2002), p. 339-353.

TAVARES, R. N.; AQUINO, E. M. F. Controle da moldagem a vácuo melhora a qualidade das peças de plásticos reforçado. Plástico Industrial, São Paulo, v. 04, dez., 1999. 
TOLEDO FILHO, R. D. Reforços Naturais: Estrutura e Propriedades Mecânicas. Rio de Janeiro: PUC (Pós-graduação), 1993.

VINCENZINE, P. Advanced structural fiber composites. Faenza, Italy: Techna Faenza, 1995.

VLACK, L. H. Princípios de Ciências dos Materiais. 8. ed. São Paulo: Edgard Blucher, 1988.

YANG, B.; KOSEY, V.; ADANUR, S.; KUMAR, S. Bending, compression and Shear Behavior of Woven Glass Fiber-Epoxy Composites, Composites - Part B:

Engineering, v. 31, 2000, p.715-721.

YOSOMIYA, R.; MORIMITO, K.; NAKAJIMA, A.; IKADA, Y.; SUZUKI, TOSHIO. Adhesion and Bonding in Composites. New York: Marcell Dekker, 1989.

YOUNG, R.A. Fibers (Vegetable). Kirk-Otthmer encyclopedia of Chemical

Tecnology. $4^{\text {th }}$. ed. v. 10. New Jersey, USA: J. Wiley \& Sons, Inc., 1994. p.727-744.

ZARATE, C. N.; ARANGUREM, M. I.; REBOREDO, M. M. Effects of fiber length in resol/sisal composites. in: INTERNATIONAL SYMPOSIUM ON NATURAL POLYMERS AND COMPOSITES, 3, São Paulo, 2000. Proceedings. São Paulo: USP/UNESP/Embrapa, 2000, p. 362-366. 